RILDO RODRIGUES GOULART

\title{
ÉDIPO REI: AS RELAÇÕES ENTRE ÉDIPO E JOCASTA
}

Dissertação apresentada ao Programa de Pós-

Graduação em Artes Cênicas, da Escola de

Comunicações e Artes da Universidade de São

Paulo, como exigência parcial para obtenção do

título de mestre em Artes, Área de Concentração

Teoria e Prática do Teatro, com Linha de Pesquisa

"História do Teatro", com orientação do Professor

Doutor Clóvis Garcia.

UNIVERSIDADE DE SÃO PAULO

ESCOLA DE COMUNICAÇÕES E ARTES

DEPARTAMENTO DE ARTES CÊNICAS

SÃO PAULO, 2009. 
RILDO RODRIGUES GOULART

ÉDIPO REI: AS RELAÇÕES ENTRE ÉDIPO E JOCASTA

Aprovada em:

Banca examinadora:

Prof. Dr.

Assinatura:

Prof. Dr.

Assinatura:

Prof. Dr.

Assinatura: 


\section{RESUMO}

O texto da tragédia grega Édipo Rei de Sófocles, do século V a.C., permite até os dias de hoje inúmeros estudos sobre seu mito, face a tamanha riqueza existente em seu mitologema. Pressuposto a tantas pesquisas existentes, elaboramos uma visão inerente aos estudos realizados, compondo uma dissertação comparativa, revisitando o texto de Sófocles e incluindo uma nova ótica sobre a tragédia do rei de Tebas.

Porém, antes de mergulharmos na essência do mito, procuramos entender a tragédia grega e seu período de existência. Da mesma forma, investigamos o homem Sófocles, artista e poeta na sociedade em que viveu, e suas relações sociais e políticas com seu amigo e estrategista Péricles.

Ponto imprescindível da dissertação é a constatação de que Sófocles fundiu em um só personagem feminino a figura das duas esposas de Laio, condensadas em Jocasta. Tornada mãe e esposa de Édipo, o personagem de Jocasta aumentou profundamente o efeito dramático desejado pelo autor grego, criando um dos maiores textos trágicos da antiguidade que chegaram até hoje.

Sem perder a essência do texto sofocliano, decodificamos o mito em suas diversas vertentes, situamos as condições sociais nas relações da mulher no século V a.C., e, assim, estabelecemos as relações que envolveram Édipo e Jocasta no conjunto poético da tragédia reelaborada por Sófocles.

\section{Palavras-Chave: Édipo Rei, Jocasta, Sófocles, Péricles e Tragédia Grega}




\section{ABSTRACT}

The text of the Greek tragedy Oedipus Rex, by Sophocles, 5th century BC, allows us, until the present days, to make innumerous studies about its myth, due to the immense richness of its mythologem. Considering so many existing researches, we have elaborated a vision inherent to the studies already done, writing a comparative dissertation, revisiting Sophocles'text and throwing some new light upon the tragedy of the King of Thebes.

However, before plunging into the essence of the myth, we have tried to understand the Greek tragedy and its existing context. In the same way, we have investigated the man Sophocles, artist and poet in the society he lived in, and his social and political relationship with his friend and strategist Pericles.

The essential point of the dissertation is the thesis that Sophocles has melted, in a single feminine character, the profiles of the two wives of Laius, condensed in Jocasta. Transformed into mother and wife of Edipo, the character Jocasta deeply increased the dramatic effect desired by the Greek author, creating one of the greatest tragic text of antiquity that have arrived to present days.

Without losing the essence of the sophoclean text, we have decoded the myth in its various aspects, contextualized the social conditions of the women's relations in the 5th century BC, and, finally, we have established the relations that involved Edipo and Jocasta in the poetic set of the tragedy re-elaborated by Sophocles.

\section{Key-Words: Oedipus Rex, Jocasta, Sophocles, Pericles end Greek Tragedy.}


Ao meu professor e Doutor Clóvis Garcia:

Orientador de homens e de almas. Senhor de uma sabedoria inigualável, que me conduziu com carinho e discernimento a desenvolver esta dissertação, uma singela dedicação para este mestre do teatro brasileiro.

Ao meu sobrinho Mauro Sérgio Goulart Simioni:

Na pureza de seus nove anos e apaixonado por mitologia grega, escreveu-me uma carta dizendo: “... tio, quero o melhor de você ...". Escrevo aqui sua merecida dedicação.

A minha mãe, Dionilze de Oliveira Goulart:

Senhora de uma alma prodigiosa e sensível. Esta mulher, guerreira e batalhadora é, sem dúvida nenhuma, o meu primeiro guia, e incentivadora de minha paixão pelas artes e finalmente pelo teatro. 
Ao diretor, ator e amigo Ewerton de Castro pela bolsa de estudos concedida em sua escola de teatro.

Ao professor Rogério Toscano, por me apresentar o texto Édipo Rei de Sófocles.

Aos atores do extinto Centro Experimental de Pesquisas e Artes Cênicas da cidade de José Bonifácio, pela montagem do espetáculo Édipo Rei.

A Haydée Bettencourt, pela supervisão do espetáculo, confiança e amizade.

Aos professores mestres e doutores Marcelo Pessoa, Leonice de Loudes B. Marão, Fausto Viana, Maria Beatriz B. Florenzano, Cyro del Nero, Eduardo Tessari Coutinho e Celso Alves Cruz.

Ao amigo Laércio Silva Raphael, pela correção gramatical e inúmeras indicações no texto final.

Aos amigos Rafael Rios, Marcos Pinto, Juliana Pedreira, Amaliani Oliveira e Cynthia Regina Fischer.

E para minha irmã Marcilene Rodrigues Goulart, pelo apoio, colaboração e incentivo. 
SUMÁRIO

INTRODUÇÃO

PÁG.VIII

\section{CAPÍtULO I}

$\begin{array}{ll}\text { A TRAGÉDIA GREGA PÁG.001 } & \text { PRA }\end{array}$

\section{CAPÍTULO II}

1.1 SÓFOCLES: O CIDADÃO E O ARTISTA

PÁG.011

1.2 SÓFOCLES E PÉRICLES

PÁG.023

\section{CAPÍTULO III}

O MITO: ÉDIPO

PÁG.037

CAPÍTULO IV

JOCASTA: MÃE, MADRASTA OU INVENÇÃO DE SÓFOCLES? PÁG.081

\section{CAPÍtULO V}

ÉDIPO E JOCASTA: A RELAÇÃO TRÁGICA

PÁG.107

CONCLUSÃO

PÁG.151

BIBLIOGRAFIA

PÁG.162 
Édipo Rei surgiu como um oráculo com bons presságios em minha vida e remexeu meus princípios, valorizou meus conhecimentos, me dando mais força e ânimo para mergulhar em sua trajetória sem me perder na encruzilhada de Defos e Dália.

Assim, como Olga Rinne ${ }^{1}$ se encontrou com Medéia em uma reunião com amigas, eu me encontrei e me deparei com esse Édipo claudicante na minha frente, diante dos meus atores em pleno palco de uma montagem teatral que fazíamos no interior do estado de São Paulo, na cidade de José Bonifácio.

O que me levou, a aprofundar-me ainda mais nessa temática, foi um comentário do professor e doutor Clóvis Garcia, em um curso que ele ministrava sobre História do teatro, na cidade de São José do Rio Preto, no primeiro semestre do ano de 2004.

Enquanto conversarmos no intervalo do curso; eu, na minha empolgação de um jovem diretor de teatro, disse que estava montando a peça Édipo Rei de Sófocles, e foi então que ele me perguntou se eu sabia de um texto de Junito de Souza Brandão, que fazia um comentário, baseado em um trecho da Odisséia, onde dizia que Jocasta não seria mãe de Édipo. Não pude conter o espanto e nem a decepção que me invadiu naquele momento. Afinal, além de diretor eu havia passado a interpretar o personagem.

\footnotetext{
${ }^{1}$ RINNE, OLGA. Medéia: o Direito à Ira e ao Ciúme. Tradução de Martincic e Daniel Camarinha da Silva. São Paulo: Cultrix, 1988.
} 
Sai do curso extremamente incomodado com aquela revelação. A partir daquele momento, algo muito mais profundo remexeu os meus conceitos e uma nova sensação tomou conta do meu espírito de ator, diretor e pesquisador de teatro. Eu não poderia ficar inerte diante de tal informação, como se nada tivesse acontecido.

A partir desse momento começaram as dúvidas e os questionamentos. Por que Édipo perfurou os olhos já que Jocasta não era sua mãe? Por que Jocasta se enforcou já que nem foi sua mãe e nem sequer sua madrasta, no sentido de não hávê-lo criado? Por que ele foi expulso de Tebas, perdeu seu trono e vagou pelo mundo como um indigente amaldiçoado, feito um bode expiatório, até conseguir, depois de muita busca e sofrimentos, encontrar abrigo no bosque das Eumênides, na colônia grega de Atenas em Colono?

Ou seja, a indignação me levou a aprofundar-me ainda mais na pesquisa e no processo de nossa montagem, tornando Édipo cada vez mais íntimo, mais próximo e mais humano, como se sua lenda tivesse que me dizer algo a mais. Algo ainda não dito. Como se seu espírito estivesse infeliz no Hades por saber que o fogo sagrado, o culto, o banquete e as libações para ele e seus ancestrais tivessem sido interrompidos de forma tão violenta.

Assim, como uma pedra de gelo leva à avalanche, um único livro pode nos levar para dentro de uma gigantesca biblioteca, onde novos caminhos se abrem em informações, imagens e histórias que vislumbram épocas e iluminam nossos espíritos. 
Comigo foi assim. Édipo e toda a sua família vieram ao meu encontro como se eu tivesse reacendido o fogo sagrado do palácio esquecido no tempo, entre os poucos escombros de uma Tebas cheia de mistérios.

Então, tomei o meu bastão e passei a peregrinar entre páginas e páginas de livros editados sobre Édipo Rei. Onde outros sábios pesquisadores nos norteiam entre tantos estudos e pesquisas sobre essa magnífica lenda. E nestes caminhos fui encontrando inúmeros textos de autores que abordavam de diversas formas o mito. Porém, para minha pesquisa, o primeiro texto a ser lido foi a Maldição dos Labdácias de Junito de Souza Brandão e a partir dele uma imensa bibliografia foi se abrindo por essa caminhada, por essas estradas antigas da Grécia, por onde Édipo, cego em sua desventura, também teve de peregrinar.

Não foi obra do acaso que me levou a desenvolver esta dissertação sobre Édipo Rei, entre tantos estudos, análises e pesquisas existentes sobre o mito de Édipo. A minha formação em história foi fundamental para me levar por tais caminhos de tantos questionamentos sobre um período histórico de extrema relevância na Grécia do século V a.C..

Século este onde o poder político do estratego e até mesmo do escritor das tragédias podia chegar a um ponto de manipular as várias versões da história oral de um mesmo mito, onde ele já se posicionava no panteão de supostas idéias da tirania obscura que se escondia por trás de estratégias que, ao meu ver, se apoderaram da democracia 
para utilizar o poder que lhes outorgaram, para transmitir seus ideais de pensamento no teatro sagrado de Dioniso.

Assim como acredito que utilizaram a tragédia não somente como uma demonstração religiosa, educadora e artística, mas também como uma obra de manipulação das massas e das idéias. A tragédia causava mudanças de pensamentos e atitudes da sociedade grega daquele período, em função do que estava sendo proposto pela dramaturgia do texto e da encenação organizada pelo dramaturgo. Acredito que os dramaturgos possam ter alterado propositadamente alguns dados do mito para fins muito mais sociais e políticos do que teatrais.

No entanto, entre os elementos que compõem minha formação, o teatro foi de todos o mais importante. Foi através dele que pude ajuntar a maioria do material colhido e criar forças para que esse êxtase dionisíaco me libertasse e possibilitasse adentrar por tais caminhos. Permitiu que eu visse além das linhas, o que estava entre o papel e a letra e que pudesse, na pesquisa investigatória, encontrar no mitologema edipiano algo que talvez não tivesse sido abordado, ou passado desabercebido por tantos estudiosos que também se embrenharam e se embriagaram com a fascinante saga deste herói.

Vasculhando os textos eu me perguntava onde estariam as principais fontes? Qual autor me daria alguma certeza do que me propus a fazer? Mesmo existindo uma vasta bibliografia, todo o material que até então tive acesso estudava a história do herói, sempre dando ênfase no rei Édipo, deixando totalmente à margem a história de Jocasta. 
Sendo ela mãe ou não de Édipo é inevítavel que falemos sobre a mãe dos quatro filhos de Édipo. Sobre a mulher que se mata no final da tragédia e que, durante toda a peça, procura afastar Édipo da busca de sua verdadeira origem e não sendo ouvida não consegue evitar a tragédia.

Como a maioria dos autores buscou em Édipo Rei suas principais fontes de pesquisa para comprovar uma tese, escrever uma dissertação ou redigir algum artigo, encontrei na atitude de Jocasta uma das principais fontes para questionar Sófocles, Péricles e a tragédia de Édipo.

Questionar Sófocles pode até parecer insano num primeiro momento porém, Aristóteles em sua Poética, considera em Édipo Rei que a peripécia e o reconhecimento criado por Sófocles no momento em que Édipo se enxerga como assassino do pai e filho de Jocasta uma das mais perfeitas cenas já elaboradas. Mas ele não vasculha o conteúdo histórico do mitologema, sua poética se preocupa em analisar a tragédia no seu contexto dramático, poético e estrutural; portanto, ele ignora historicamente quais foram e/ou quais deixaram de ser as personagens da peça. Daí o meu desejo de investigar com mais profundidade o universo no qual Sófocles estava situado.

Da mesma forma que questionamos Sófocles, iremos posicionar e questionar Péricles, o homem de espirito elevado, com ar grave e severo, jeito de andar firme e tranqüilo, cujo tom de voz era sempre igual, um homem que jamais conseguia se alterar em público, ou seja, um homem político e socialmente correto. O homem perfeito e idealizado, o homem que não caiu na desmedida, que não saiu do métrom. 
Para uma época que precisava de alguém com esse porte, Édipo Rei seria a peça ideal para reafirmar o poder divino ou tirânico de Péricles, ou seja, o Édipo de Sófocles, que numa analogia a Péricles fez o oposto do estratego. Édipo ultrapassou o limite, o métron; caiu na desmedida, na hybris; despertou o némesis, o ciúme divino; incorreu na até, na cegueira da razão; e despencou na moira, no seu destino, na sua sina, enfim, tudo o que um homem grego de sua época não podia ser ou fazer.

Sendo as dionisíacas urbanas uma obrigação religiosa para os gregos, não poderia haver fuga da catarse, do terror, da purgação. O mito enraizado no pensamento e na vida do homem grego do século V a.C. estaria ali, na sua frente, sendo representado de forma magnífica por um dos maiores encenadores, que adorava fazer o grande espetáculo e que, possivelmente, poderia transformar idéias e consequentemente o homem.

Assim, religião, sociedade, política e teatro se uniram para transformar Édipo Rei numa grande aula que pode pressupor uma utópica e intrigante democracia, onde o jogo de interesses passou a falar muito mais alto que o mitologema edipiano, que a história oral e a história factual.

Porém, recortando a peça como um cirurgião que opera uma doença, a tragédia de Sófocles vai se abrindo num campo muito mais amplo das ciências humanas, possibilitando a nós, pesquisadores do universo teatral, perceber que sua obra é belíssima; no entanto, contem inúmeros deslizes históricos (maiores ou não), que paulatinamente serão analizados no decorrer desta dissertação. 
Sendo assim, propomos uma dissertação que visa analisar a relação trágica entre Édipo e Jocasta, investigando as variantes do mito edipiano a partir do texto trágico de Sófocles. Assim, levantamos paradigmas estabelecidos para situarmos nossos questionamentos com novas análises sobre a maternidade de Jocasta e o incesto de Édipo existente na tragédia.

O interesse por um tema que se proponha averiguar o mérito das manifestações teatrais no cenário da antiguidade grega, relacionando-as com os estudos clássicos e modernos, prende-se ao fato do tema tangenciar a questão da ética e do teatro como fonte de pesquisa da história do teatro e seu vínculo com o presente.

Desta forma, nosso objeto de pesquisa necessita um recorte sincrônico no passado, especificamente no século V a.C., no período de gestão do estrategista Péricles e sua relação com Sófocles, mito, teatro e política. Tal panorama permite melhor situar o objeto primordial desta dissertação, as relações de Édipo e Jocasta e o legado da tragédia sofocliana como fonte de pesquisa para o teatro e sua história.

Diante desse quadro, compõem o corpus principal de nossa justificativa a análise da tragédia grega Édipo Rei de Sófocles. Além deste texto, são utilizados diversos estudos realizados por inúmeros pesquisadores, pois parecem inserir-se justamente no centro de lacunas do Édipo Rei. Possibilitam uma revisão de idéias e críticas sobre as relações históricas, sociais, políticas e teatrais que envolvem a informação mitológica e 
teatral do homem no cenário social do século de ouro da Grécia, o qual nos permite recorrer como apoio técnico-teórico complementar ao corpus principal.

A metodologia aplicada para a elaboração e construção desta dissertação é a pesquisa bibliográfica com análises comparativas, textos trágicos, ou pesquisas e estudos sobre o teatro grego. O Édipo Rei de Sófocles é o texto central para toda e qualquer análise comparativa com outros textos trágicos e estudos realizados por outros pesquisadores.

O objeto de pesquisa literária abordado para essa dissertação exige um critério muito singular na abordagem de nosso tema, porém seguem aqui descritas, de maneira bem sintetizada, não todas as obras que estão na bibliografia, mas um resumo parcial de alguns dos principais livros que são indispensáveis para adicionar clareza e conhecimento neste trabalho.

Peças fundamentais para absorção do conteúdo estão presentes nas obras trágicas de Ésquilo, Sófocles, Eurípedes e Aristófanes, escritas no período que direcionamos nossa dissertação, trazem informações precisas sobre a tragédia e a história do século $\mathrm{V}$ a.C.. Com tradução do grego de Mário da Gama Kury nas edições da editora Jorge Zahar, a leitura e apreciação destes clássicos formam um conjunto singular das tragédias e comédias traduzidas para o português, com informações preciosas e claras para nosso estudo. De cada autor estudamos e utilizamos as seguintes obras: 
De Sófocles utilizamos as seguintes tragédias: Édipo Rei, Édipo em Colono, Antígona, Electra, As Traquínias, Ájax e Filoctetes.

De Aristófanes usamos: As nuvens, Só para mulheres, Um deus Chamado dinheiro, As vespas, As aves, As rãs, A greve do sexo (Lisístrata), A revolução das mulheres e A paz.

De Ésquilo estudamos: Agamêmnon, Coéforas, Eumênides, Os Persas, Prometeu Prisioneiro e Os sete contra Tebas.

Eurípedes: Medéia, Hipólito, As Troianas, Hécuba, Ifigênia em Áulis, As Fenícias e As Bacantes.

No universo da mitologia e seu entendimento maior, Junito de Souza Brandão e seu Mitologia Grega, editado pela Vozes, com seus volumes I, II e III, esclarecem dúvidas sobre o mito e desmitificam conceitos arcaicos.

Fustel de Coulanges, com seu livro A Cidade Antiga: Estudos sobre o Culto, o Direito, as Instituições da Grécia e de Roma, editado pela Hemus em 1975, nos posiciona diante da história com uma veracidade que poucos historiadores conseguem realizar.

Werner Wilhelm Jaeger nos apresenta o universo da formação do homem grego em sua Paidéia: a Formação do Homem Grego, com tradução de Artur M. Parreira, 
editado no Brasil pela editora Martins Fontes em 1986, uma das maiores fontes de pesquisa sobre o homem grego, tornado obrigatório para qualquer estudo sobre a Grécia a sua leitura.

Bernard Knox atualiza Édipo Rei, com comparações e citações fundamentais para avaliar a personagem de Sófocles e Péricles em seu livro Édipo em Tebas, com tradução de Margarida Goldsztyn, editado pela Perspectiva em 1988.

E para entender Péricles e seu período três autores foram primorosos neste estudo inicial: Jean-Jacques Maffre em O Século de Péricles, da Edições e Publicações Europa-América Ltda de Portugal, Claude Mossé com sua obra, Atenas: a História de uma Democracia, com tradução de João Batista da Costa, editado pela Editora Universidade de Brasília em 1997 e Plutarco com seu magnífico estudo sobre Péricles Reformador de Atenas, editado em Lisboa, Portugal pela editora Inquérito em 1938.

Olga Rinne esclarece o universo feminino do século V a.C. com Medéia: o Direito à Ira e ao Ciúme da Editora Cultrix. 1988. São Paulo, S.P.

Assim como Tucídides em a História da Guerra do Peloponeso, editado pela Universidade de Brasília em 2001, relata uma Grécia bélica com uma verdade que somente ele pode presenciar.

Jean-Pierre Vernant e Pierre Vidal Naquet, com seus livros Mito e Tragédia na Grécia Antiga, Mito e Pensamento entre os Gregos: estudos de psicologia histórica 
e As Origens do Pensamento Grego, editados pela Perspectiva em 1999 e editora Difel em 2002, fazem jus ao nome de maiores estudiosos sobre a vida, formação e o pensamento do homem grego, tornando fundamental sua leitura e fornecendo citações em nossa dissertação.

É evidente que todos estes procedimentos, leituras e estudos de toda a bibliografia exposta no final desta dissertação não formarão a verdade absoluta sobre as relações de Édipo e Jocasta. No entanto, corroborarão para esclarecer nossas dúvidas existentes no texto trágico de Sófocles, colaborando com mais uma pesquisa para a história do teatro e um entendimento mais aprimorado sobre a tragédia do rei Édipo. 
CAPÍTULO I

A TRAGÉDIA GREGA

"A vontade de um deus tem muitas formas e muitas vezes ele surpreende-nos na realização de seus desígnios.

Não acontece o que era de esperar e vemos no momento culminante o inesperado. Assim termina o drama”.

( Eurípides - As Bacantes: Coro - versos 1827 aos 1902) 
Grécia. Século V a.C.. Os primeiros raios do sol incidem no monumental edifício de mármore pentélico, refletindo uma luminosidade avermelhada em suas colunas e pórticos. Ao meio-dia, as mesmas colunas tomavam a cor de um amarelo intenso, onde o deus Hélios incidia no naos seus poderosos raios na imensa estátua de ouro e marfim da deusa Atenéa Partenos, que irradiava seus reflexos dourados por todo o templo. Com a luz do entardecer, a gigantesca construção adquiria um brilho violeta azulado que aos poucos desaparecia no crepúsculo frouxo que delineava as silhuetas de um padrão clássico de beleza única que foi o Pártenon.

Desde o ano 800 a.C., aproximadamente, o monte calcário no qual se encontra a Acrópole de Atenas, nome que significa "cimo da cidade", foi uma construção que se desenvolveu paulatinamente como distrito sagrado; a partir de então a cidade foi estabelecendo-se em sua base. Construíram-se diversos edifícios de culto, entre eles um templo dedicado a Atenea Polias, a deusa "protetora da cidade"; no entanto, essas construções foram destruídas pelos persas em 480 a.C ${ }^{1}$.

A reconstrução, na sua forma atual, data dos tempos de Péricles, no século V a.C. entre os anos de 448 a 432 a.C. que, encarregado da reconstrução das "ruínas Persas", como ficou conhecida a Acrópole de Atenas, encarregou seus principais arquitetos da época, Ictino, Calícrates, Mnésicles e Coroibo; os escultores Paiono, Alcâmenes, Agorácrito, Cresilas; e os pintores Polignoto e Cololes da reedificação do Pártenon e entregou o projeto para seu amigo Fídias, além da realização de toda a decoração. Desta

${ }^{1}$ DURANDO, Furio. Grandes Civilizações do Passado: A Grécia Antiga. Tradução de Carlos Nougué. Direção geral de José Luis Sanchez e Meritxell Almarza. Barcelona: Portugal. Edizione White Star e Folio: 2005. 
forma, uma multidão de profissionais, operários e ajudantes ergueram monumentos e realizaram construções belíssimas e grandiosas que perdurariam séculos, para serem construídas, no entanto foram erguidas em apenas um período político de um único homem.

Entre tantas construções uma delas, já formalizada anteriormente no governo de Pisístrato e enaltecida no governo de Péricles, faria a grande diferença da sociedade grega e de todas as outras até então conhecidas e daquelas que viriam: o teatro grego. Esta monumental construção idílica, elaborada na mais simples e preciosa das formas, foi um marco na formação do teatro ocidental.

Da estrutura física ao universo mais amplo da sociedade grega, o teatro dos deuses imperdoáveis de Ésquilo, do herói humano e idealizado de Sófocles, do contraste implacável e impactante de Eurípedes ao escancaramento no deboche óbvio e político de Aristófanes, o teatro ático resultou na mais importante obra de arte social e verdadeira existente na Grécia. No entanto, para repercutir em tamanha grandeza, o teatro grego com suas tragédias e comédias, surgiu em um campo fértil das mentalidades humanas que existe na essência do homem, nesse ato inconsciente do dar e do receber, nessa forma sagrada de ser possuído, dominado, inflamado pelos deuses ou ser ele próprio. Assim, o berço da arte dramática grega vai encontrar na máscara mágica, no ritual dos sacrifícios, nas danças e no culto o princípio da tragédia.

Iaco, Zagreu ou Baco, Dioniso sempre teve vários nomes; seu mito inúmeras variantes, mas, é deste deus que morre e renasce e da adoração a seu culto que a tragédia 
vai se embebedar com seu vinho sagrado e imolar o secular bode, para que num êxtase de criação permitam que todas as divindades, heróis e seres fabulosos renasçam dignamente no seio do teatro.

Assim, a arte da imitação sempre foi um elo de ligação entre o homem e as divindades e "em todas as partes da terra se encontraram, a partir dos estágios mais remotos dos coletores e primitivos caçadores, celebrações mímicas, danças com máscaras, sobretudo, que têm seus paralelos no mais antigo culto grego",2, realizadas nas aldeias primitivas da antiga Grécia.

Mas não se tratava apenas de se colocar uma máscara de um animal qualquer e dançar freneticamente ao som de címbalos que o homem e o deus se metamorfosiavam em semi-divindades, era necessário, antes de tudo, crer. Assim como a criança simula os atos dos adultos e o selvagem, que rabisca na parede da gruta a caça do amanhã e acredita nisso, da mesma forma o rito penetra nas entranhas do individuo e o transforma.

Então, Dioniso, filho da mortal Sêmele com Zeus, vai aos poucos invadindo o inconsciente humano através do rito fermentado no vinho pisado pelos vinhateiros áticos e realiza a transformação no ser que o deseja.

Margot Berthold, em seu livro História Mundial do Teatro, diz o seguinte:

\footnotetext{
${ }^{2}$ LESKI, Albin. A Tragédia Grega. Tradução de J. Guinsburg. São Paulo: Editora Perspectiva. 1976. pág.
} 48. 
"[...] para a Grécia homérica isso significa os sagrados festivais báquicos, menádicos, em homenagem a Dioniso, o deus do vinho, da vegetação e do crescimento, da procriação e da vida exuberante. Seu cortejo é composto por Sileno, sátiros e bacantes. Os festivais rurais da prensa do vinho, em dezembro, e as festas das flores de Atenas, em fevereiro e março, eram dedicados a ele. [...."

Esse deus móvel e nômade que assume várias formas da vida divina e humana vai se popularizar em diversos povos da antiguidade. As festas de Baco, radiosas e terríveis, propícias e funestas, lacrimosas e sorridentes, lembrando a vitória ou o martírio, pululam da Jônia à Trácia, da Beócia à Ática, atravessam o mar, invadem as Cíclades e dominam o Arquipélago grego.

Segundo Paul de Saint-Victor em seu livro As Duas Máscaras diz que:

"[...] Baco vem de um lar ariano; nasceu do suco do soma, a planta fermentada, o vinho da Ásia que os patriarcas védicos derramavam sobre a chama do altar para espevitá-la. Gerado num copo, como convinha a seu destino, personifica a libação dos sacrifícios mesclada ao fogo - agni - que ela alimenta e com o qual se identifica, indo levar ao céu, num turbilhão de fagulhas, as preces

\footnotetext{
${ }^{3}$ BERTHOLD, Margot. Historia Mundial do Teatro. Tradução de Maria Paula Zurawski, J. Guinsburg, Sérgio Coelho e Clóvis Garcia. São Paulo: Ed. Perspectiva, 2001. pág. 103.
} 


\section{dos homens e sua própria essência, que os deuses sorverão. $[. . .]^{4,}$}

É deste soma que Dioniso vai alimentar os grandes vinhedos gregos nas festas campesinas, ainda longe das pompas da gloriosa Atenas. Lá, junto ao povo da terra, ele preside o rito que abençoa a vinha. Sua estátua grosseira esculpida em madeira, precedida por um odre enfeitado de parras, com um bode carregando um cesto de figos e uma escrava balançando ingenuamente um falo, símbolo da fertilidade, a procissão marcha em volta da plantação para no final de tudo se entregar a grande cerimônia final, onde o vinho amassado se torna o precioso néctar.

Esses adeptos do deus do vinho se entregavam a imaginação popular e usando máscaras de bodes, disfarçavam-se em sátiros, assim, todos bebiam e dançavam ao som vertiginoso dos címbalos, embriagados no delírio báquico até caírem semidesfalecidos por terra, e neste êxtase satírico se transmutavam no próprio deus.

Destes homens-bodes, teria nascido o vocábulo tragédia, que da junção das palavras trágos (bode) e oide (canto), daí a palavra do grego tragoidía, que para o latim será tragoedia e para nossa língua tragédia.

Foi assim que a máscara ganhou vida e se tornou trágica. Esse deus possuidor das orgias desenfreadas, das danças voluptuosas, dos cânticos enaltecidos em alternados

\footnotetext{
${ }^{4}$ SAINT-VICTOR, Paul de. As Duas Máscaras. Tradução de Gilson César Cardoso de Sousa. São Paulo: Editora Germape. 2003. Pág. 19.
} 
ditirambos e das canções báquicas atenienses, se deslocará do campo com seus ritos, para pousar no seio do teatro grego e tornar-se o seu deus.

Segundo Jean-Pierre Vernant, em seu livro Mito e Tragédia na Grécia Antiga a tragédia clássica tornou-se:

\author{
"Gênero literário original, possuidor de regras e \\ características próprias, a tragédia instaura, no sistema \\ das festas públicas da cidade, um novo tipo de \\ espetáculo; além disso, como forma de expressão \\ específica, traduz aspectos da experiência humana até \\ então desapercebidos; marca uma etapa na formação do \\ homem interior, do homem como sujeito responsável. \\ Gênero trágico, representação trágica, homem trágico: \\ sob esses três aspectos, o fenômeno aparece com \\ caracteres irredutíveis."5
}

Agregada ao seio da cidade grega o ritual dionisíaco sai do campo puramente ritualístico para se incorporar no padrão de vida cultural do homem ático, na representação teatral dos grandes tragediógrafos de uma época específica na Grécia antiga entre o final do século VI a.C. até o final do século V a.C., ou seja, a tragédia grega aparece como um

\footnotetext{
${ }^{5}$ VERnANT, Jean-Pierre; VIDAL-NAQUET, Pierre. Mito e Tragédia na Grécia Antiga I e II. Tradução de Anna Lia A. de Almeida Prado, Filomena Yoshie Hirata Garcia e Maria da Conceição M. Cavalcante. São Paulo: Ed. Perspectiva. 1999. Pág. 01.
} 
momento histórico único, delimitado e datado com muita precisão. Vêmo-la nascer em Atenas, ali florescer e degenerar quase no espaço de um século.

Ela, que tem sua semente nos rituais campesinos com homens mascarados travestidos de animais, tinha uma função especificamente religiosa e sagrada, a partir do momento que emerge no teatro grego perde essa função ritualística para incorporar a máscara humana e não mais um disfarce animal. Seu papel torna-se estético e não mais ritual, torna-se social-político-religioso e não somente religioso.

A máscara do bode não tem mais sua forma original, ela agora se reveste de realeza e grandiosidade. Sua função é representar as grandes personagens heróicas e seus conflitos, "que a linguagem do homem comum torna mais próximas, não são trazidas à cena diante dos olhos de todos os espectadores, mas também tornam-se objeto de um debate através das discussões que as opõem aos coristas ou umas às outras; elas,

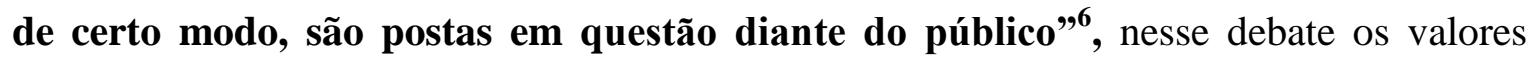
heróicos são discutidos, avaliados e questionados.

A obra trágica traz o mito em cena e sobre ele discute os novos valores humanos a luz do pensamento jurídico que desponta na sociedade ateniense. O teatro não é um local de diversão e entretenimento é uma assembléia para discussões do direito e das responsabilidades do novo homem, centro dos novos valores sociais de Atenas.

\footnotetext{
${ }^{6}$ VERnANT, Jean-Pierre; VIDAL-NAQUET, Pierre. Mito e Tragédia na Grécia Antiga I e II. Tradução de Anna Lia A. de Almeida Prado, Filomena Yoshie Hirata Garcia e Maria da Conceição M. Cavalcante. São Paulo: Ed. Perspectiva. 1999. Pág. 02.
} 
Desta forma os poetas trágicos possibilitam e deliberam uma discussão de incertezas, imprecisões e discordâncias que ainda planam no seio do próprio pensamento jurídico. Da mesma forma colocam em xeque-mate os conflitos da tradição religiosa e das responsabilidades morais que dizem respeito ao homem, confrontando o homem com ele mesmo, onde ele terá que fazer uma escolha definitiva e se orientar num universo de valores ambíguos e instáveis.

Assim, o campo fértil da tragédia e sua força teatral estão na lenda dos grandes heróis gregos, na tradição das narrativas míticas, mas mantém um distanciamento em relação àquilo em que se inspira. Procura situar-se nessa zona fronteiriça onde os atos humanos se articulam e se debatem com as potências divinas e buscam revelar seu verdadeiro sentido.

Desta forma, a tragédia grega está situada num espaço ainda ambíguo da cidade. Seus questionamentos e imposições pairam num universo que ainda não se formou no seio da sociedade em plena mudança. Os valores do homem ateniense do século V a.C. estão em questionamento, dúvidas e incertezas. A democracia ateniense vive seu instante de afirmação dos novos valores do homem que a partir desse momento não é mais um objeto de manipulação dos deuses, mas ainda os teme. Este comportamento duplo do homem é o reflexo de sua vida cotidiana e a tragédia é o reflexo de seu estado psicológico representado no teatro grego. Ela bebe a essência do mito e transporta-o para a cena teatral onde o homem se vê em toda a sua amplitude de caracteres. 
Assim, esse homem trágico se enxerga e se liberta para Dioniso realizar a sua cirurgia do êxtase. É na transgressão da alma que a tragédia vai realizar sua maravilhosa função no horror e na piedade para reformular o pensamento do homem ateniense e causar sua magnífica transformação. 


\subsection{SÓFOCLES: O CIDADÃO E O ARTISTA}

"É uma verdade admitida há muito tempo entre os homens que não se pode saber, de nenhum mortal, antes que morra, se a vida lhe foi suave ou cruel".

(Sófocles - As Traquínias: Dejanira - versos 1 aos 3) 
No que diz respeito à vida de Sófocles, sabemos que ele foi um dos trágicos mais venerados de seu tempo. Escreveu aproximadamente 123 peças teatrais e obteve 24 vitórias nos concursos trágicos, o que significa que 76 de suas obras foram premiadas e nunca ocupou o terceiro lugar, feitos jamais igualados na história literária de Atenas.

Desta vasta produção chegaram até nossos dias sete tragédias completas: Ájax, Antígona, Édipo Rei, As Traquínias, Electra, Filoctetes e Édipo em Colono. Temos ainda um drama satírico incompleto - Cães de Caça - e inúmeros fragmentos de outras peças que se perderam na vastidão do tempo.

Nasceu no demo de Colono, nos arrabaldes de Atenas, no ano de 496 ou 495 a.C. e faleceu em 406 ou 402 a.C., (infelizmente não temos a data precisa de seu nascimento e morte). No entanto, podemos dizer que Sófocles não teve nada de trágico em sua vida, ao contrário das suas tragédias. Seu pai, Sófilos, era um rico ateniense dono de escravos, ferreiros e carpinteiros, o que lhe permitiu ter um estudo e formação digna de um homem ateniense e poder fazer parte da minoria dos habitantes de Atenas.

Foi um homem altamente público e político durante muito tempo, “o que o difere tanto de Ésquilo ${ }^{7}$, esse cidadão simples, combatente de Maratona e Salamina, mas que nunca ocupou cargo algum, como de Eurípides ${ }^{8}$, esse homem doméstico

\footnotetext{
${ }^{7}$ Ésquilo foi o mais antigo dos dramaturgos gregos e criador da tragédia em sua forma definitiva. Nasceu em Eluesis em 525 ou 524 a.C. e morreu no ano de 456 a.C.. Escreveu cerca de 90 peças, mas somente 07 chegaram até nós. Mas é dele a única trilogia inteira que conhecemos: a Oréstia.

${ }^{8}$ Eurípides nasceu em Salamina, provavelmente em 485 a.C. e morreu em 406 a.C.. São dele tragédias memoráveis como Medéia, As Troianas, As Bacantes entre outras. De suas 92 peças chegaram até nossos dias apenas 19 delas.
} 
que morreu, pouco antes do mais velho, Sófocles, na corte do rei da Macedônia"," como diz Jean-Pierre Vernant e Pierre Vidal-Naquet, em seu livro Mito e Tragédia na Grécia Antiga. Sua longa carreira política, foi favorecida provavelmente por seus sucessos como autor trágico e não especificamente como homem político.

Enquanto Ésquilo lutava na batalha de Salamina, Sófocles cantava no coro de meninos do Pean Triunfal, de quem postumamente iria admirar, reverenciar e se inspirar para nortear as suas peças. Seu caráter se desenvolverá diferente do tragediógrafo que tanto o inspirou, pois o jovem cresceu e se formou homem numa grande época de Atenas, como diz Albin Leski, "mas era outra essa grandeza que a da época dos Persas. Não foi a aflição nem a preservação através dos deuses que a produziu, mas a esplêndida realização de orgulhosas idéias de poder" ${ }^{\text {"10 }}$. Assim, as forças dos helenos se unem e adquirem formas mais sólidas. O início de uma nova jurisprudência e cunhagem de moeda única estabelece nesse povo, que vivia no campo do separatismo, o contorno de um novo império ático.

Por trás desse novo império ateniense está a figura do estrategista Péricles e Sófocles chega à idade adulta vislumbrado com as grandes construções da nova Atenas, da Acrópole no monte dos deuses e da arte grega que, neste período, chega ao seu apogeu, juntamente com uma nova democracia que parecia ter alcançado formas duradouramente sólidas, como afirma Albin Leski:

\footnotetext{
${ }^{9}$ VERNANT, Jean-Pierre; VIDAL-NAQUET, Pierre. Mito e Tragédia na Grécia Antiga I e II. Tradução de Anna Lia A. de Almeida Prado, Filomena Yoshie Hirata Garcia e Maria da Conceição M. Cavalcante. São Paulo: Ed. Perspectiva. 1999. Pág. 267.

${ }^{10}$ LESKY, Albin. A Tragédia Grega. Tradução de J. Guinsburg, Geraldo Gerson de Souza e Alberto Guzik. São Paulo: Ed. Perspectiva. 1976, 2a . Pág. 120.
} 
“O espírito de Maratona transformou-se em lenda, novas aspirações intelectuais tentavam configurar a imagem do mundo sem a presença dos deuses que lá haviam tomado parte nas lutas. A solidez dessa forma de governo estava garantida, na verdade, por um único homem, o seu dirigente, e já se faziam sentir as forças que, após a sua retirada, a desintegrariam"11.

É deste meio de tensões e falsas imagens de homens serenos, corretos e complacentes que Sófocles vai criar as mais trágicas figuras da cena Ática, descrevendo em sua obra os mais terríveis tormentos da figura humana.

Quando Sófocles representou sua primeira tetralogia, o Triptólemo (que pouco conhecemos a não ser por alguns retalhos de papiros e pergaminhos) e foi vencedor, ainda não tinha completado trinta anos, porém, "foram tão extraordinárias as circunstâncias desse triunfo. Tão grande foi a impressão causada pela representação, que o arconte diretor dos jogos transferiu ao conselho dos estrategas, sob Cimon, o julgamento que geralmente era proferido por juízes específicos, escolhidos por sorteio" "12, foi assim que o homem de seres trágicos, idealizados como se tivessem corpo e alma, adentrou a cena teatral nas dionisíacas, como um dos maiores tragediógrafos da história do teatro grego.

\footnotetext{
${ }^{11}$ LESKY, Albin. A Tragédia Grega. Tradução de J. Guinsburg, Geraldo Gerson de Souza e Alberto Guzik. São Paulo: Ed. Perspectiva. 1976, 2a. Pág. 120.

${ }^{12}$ LESKY, Albin. A Tragédia Grega. Tradução de J. Guinsburg, Geraldo Gerson de Souza e Alberto Guzik. São Paulo: Ed. Perspectiva. 1976, 2ª Pág. 121.
} 
Poderíamos dizer que como ator Sófocles foi um excelente autor. Tentou a representação como Ésquilo nos primeiros tempos de seu trabalho criador, mas abandonaria logo em seguida a vida de ator devido à fraqueza de sua voz. Mas é certo que se diga: como autor deixou peças trágicas muito mais relevantes do que a sua pequena passagem como intérprete. Peças teatrais com personagens tão brilhantes e fabulosas que, até nos dias de hoje, desafiam os mais célebres atores do teatro contemporâneo.

Como autor, tem suas raízes fincadas na tradição, porém agrupadas com o novo espírito de sua época. É com Sófocles que o coro passará de doze para quinze e será ele o introdutor do terceiro ator na tragédia, tornando-a mais dinâmica e reduzindo a quantidade de falas utilizada no coro. Agregando-se a essas mudanças a característica realista que o autor insere em suas personagens, a cena teatral grega explode na emoção do terror e da piedade com que atinge o público que assiste a encenação.

“Em Sófocles, ao revés, o teatro é essencialmente antropocêntrico, que a dizer, o herói é dotado de vontade, de uma vontade livre para agir, pouco importa quais sejam as conseqüências, e os deuses agem, mas sua atuação é à distancia, por meio de adivinhos e de oráculos: Tirésias e o Oráculo de Delfos têm sempre um encontro marcado com seus heróis" ${ }^{\prime 3}$, numa época em que o homem torna-se o senhor de tudo, a identificação do homem grego com a obra trágica de Sófocles torna-se um feliz encontro para uma catarse completa.

\footnotetext{
${ }^{13}$ BRANDÃO, Junito de Souza. Teatro Grego: Tragédia e Comédia. Rio de Janeiro: Ed. Vozes, 2001, $8^{\text {a }}$ ed. Pág. 42 e 43
} 
Ali, com a representação no centro da orquestra, o homem se enxerga, se vislumbra e se embebeda num delírio báquico e com isso se fortalece. A imagem do herói é a sua imagem. Homem e personagem se encontram num diálogo tão real quanto suas crenças e seus desejos de vida. Sófocles não é apenas um escritor de tragédias, é também um humanista. Um homem que entende seu tempo e dele tira proveito, essência e realidade de um passado distante, transformado em cena no presente.

Com Sófocles o mito não é apenas uma lenda: é um remédio para enaltecer a glória ateniense. Com ele o herói surge de dentro para fora, num drama que não se distancia em nada do drama atual. É o homem que age independentemente do que aconteça. Ele é dono dos seus atos, da sua desmedida e consequentemente do seu desabamento ou glória.

Sófocles viveu numa época em que o coletivo já não era o mais importante e sim o individual. E Jean-Jacques Mafre acrescenta, “com Sófocles, a tragédia prende-se mais com o indivíduo, que é, a partir de agora, confrontado com uma escolha onde se manifestará a sua própria responsabilidade; ilustra na ação, as grandezas do

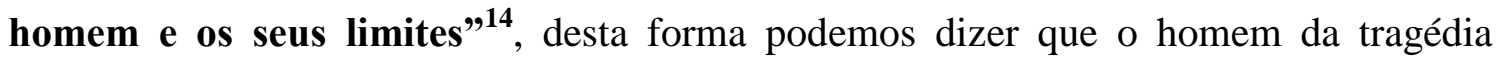
sofocliana é um indivíduo livre em seus atos, mas está sempre vigiado pela moira, que a qualquer momento age quando esse homem sai do métron, ou seja, da medida de cada um. O que exige do herói uma vigilância constante, onde a mesma prática se instaura no público que o assiste.

${ }^{14}$ MAFFre, Jean-Jacques. O Século de Péricles. Tradução de Maria do Carmo Pires. Lisboa: Ed. Publicações Europa-América Ltda. 1990. 
No seu livro A Técnica Dramática de Sófocles, Wilamowitz Moellendorff diz que "quando, por fim, determinou-se com maior precisão o lugar de Sófocles na constelação dos trágicos, foi necessário procurar em outro lugar o segredo de seu êxito, e foi na pureza de sua arte que foi encontrado. Nascida de Ésquilo, que era seu deus, e desabrochada na juventude de Sófocles, atingiu a plenitude tomando como lei suprema a obtenção do efeito cênico" "15, esse traço seria marcante na obra de Sófocles, tanto que suas tragédias superam o tempo e desabrocham novamente em nossa época em diversas interpretações de suas obras, atingindo uma dramaticidade que poucas peças trágicas conseguem manter no campo da encenação teatral.

Fica então evidente que suas peças não são apenas um relato de tempos heróicos, mas donas de uma propriedade dramática exemplar, capazes de determinar e exemplificar o padrão do homem que se idealizava no seu período. Ou seja, observador dos costumes de uma nova geração de gregos "talvez nada nos custe mais a compreender do que o enigma da sabedoria tranqüila, simples, natural, com que ele ergueu aquelas figuras humanas de carne e osso, repletas das paixões mais violentas e dos sentimentos mais ternos, de grandeza heróica e altiva e de autêntica humanidade, tão semelhantes a nós e ao mesmo tempo dotadas de tão alta

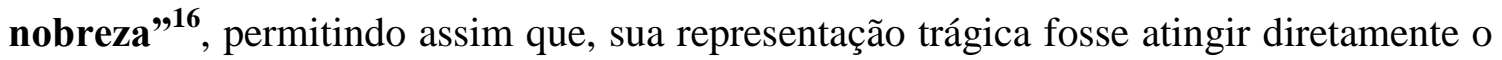
coração de um povo que necessitava ser tocado para encontrar, na representação teatral

\footnotetext{
${ }^{15}$ JAEGER, Werner Wilhelm. Paidéia: a Formação do Homem Grego. Tradução de Artur M. Parreira. São Paulo: Ed. Martins Fontes. 1986. Pág. 220.

${ }^{16}$ JAEGER, Werner Wilhelm. Paidéia: a Formação do Homem Grego. Tradução de Artur M. Parreira. São Paulo: Ed. Martins Fontes. 1986. Pág. 221.
} 
sofocliana, a sua própria identidade e o seu eu escancarado no desfecho trágico do herói com o qual se identificavam.

Quando Werner Wilhelm Jaeger comenta em sua Paidéia: a Formação do Homem Grego o efeito cênico na obra de Sófocles, ele também está se referindo que as formas de representação nos teatros gregos não eram meras encenações. O diretor de um espetáculo era amparado por uma parafernália de equipamentos existentes na cenografia e no palco que não deixava a desejar em nada a uma grande produção teatral dos dias de hoje. A única diferença é que eles usavam madeira e cordas no lugar do ferro, alumínio, fibra de carbono e cabos de aço.

Dário Fo, em seu livro Manual Mínimo do Ator acrescenta:

"[...] Os truques e os achados dos atores gregos, porém, não se limitaram ao uso dos coturnos e às deformações obtidas pelo efeito da obliqüidade pela iluminação, os gregos inventaram praticamente tudo aquilo que se usa modernamente no teatro: aparelhos cênicos, maquinas, andaimes, guindastes, pontes rolantes, carrinhos, efeitos sonoros e fogos de artifício. [.... $]^{\text {17 }}$

Com isso, obtinham um efeito cênico que deslumbrava o público que ali assistia aos espetáculos. Ou seja, tudo era muito bem elaborado, pensado, confeccionado e

\footnotetext{
${ }^{17}$ FO, Dario. Manual Mínimo do Ator. Tradução de Lucas Baldovino e Carlos Dadid Szlak. São Paulo: Editora SENAC. 1998. Pág. 259.
} 
ensaiado para as encenações dos espetáculos, tanto trágicos como cômicos, no século $\mathrm{V}$ a.C..

Ir ao teatro era uma obrigação do povo genuinamente grego. A designação sagrado e profano, não interessavam a ninguém, pois para esse povo essa denominação não existia. As grandes Dionisíacas existiam na sua excelência de ser. $\mathrm{O}$ teatro era o grande encontro de idéias colocadas em discussão para quem ali estivesse. O seu efeito perturbador tinha um sentido, pois nada que recreie o homem ateniense é sem sentido.

A nova geração necessitava de algo que ao mesmo tempo aliviasse e orientasse seus espíritos. Sendo o teatro algo obrigatório, ele cumpria sua função. E Sófocles, o criador ímpar de caracteres e imagens tragicamente deslumbrantes, foi um gênio da essencialidade no momento do homem individual.

“Não é sem razão que o coro das tragédias de Sófocles repete constantemente que a fonte de todo o mal é a ausência da medida. A harmonia preestabelecida entre a arte escultórica de Fídias e a poesia de Sófocles tem o seu fundamento mais profundo na submissão religiosa a este conhecimento da medida"18 . Conhecimento que estava disseminado na mais profunda essência do povo grego e que, a partir de suas encenações, reverberava no inconsciente coletivo numa profundidade e força na qual o povo, dominado pela ação dramática do que acabou de ver, instituía como padrão de vida.

\footnotetext{
${ }^{18}$ JAEGER, Werner Wilhelm. Paidéia: a Formação do Homem Grego. Tradução de Artur M. Parreira. São Paulo: Ed. Martins Fontes. 1986. Pág. 226.
} 
“É em Sófocles que atinge o apogeu o desenvolvimento da idéia grega de medida, considerada como o mais alto valor. É a ele que leva e é nele que se encontra a sua clássica expressão poética, como força divina que governa o mundo e a vida"19. E assim o poeta modela e representa os homens como eles devem ser. Consciente ou não da sua escrita trágica, o criador de homens e almas no teatro grego do século V a.C., inaugura uma nova ideologia da arete humana no conceito, não apenas do comportamento social, mas na educação diária dos atenienses.

Estes homens "tal como devem ser" não é uma obra apenas de Sófocles, eles já davam seus primeiros passos na vida de Atenas com Prometeu, Agamêmnon e Orestes; (tragédias de Ésquilo), mas serão reforçados numa base sólida de comportamento civil nas tragédias de Sófocles. Com ele, esses heróis serão formados de uma grandeza idealizada na mais alta estirpe da arete. De Ájax a Édipo em Colono todas as suas personagens tombaram sobre esse ideal, compondo o estilo de vida do homem da medida. Todos nascem de uma beleza e sentimento que até então nunca se tinha visto.

"A elevação dos seus grandes sofredores à mais alta nobreza é o sim que Sófocles da a essa realidade, a esfinge cujo enigma fatal consegue resolver. É o homem trágico de Sófocles o primeiro a elevar-se a uma autêntica grandeza humana, pela completa destruição da sua felicidade terrena ou da sua existência

\footnotetext{
${ }^{19}$ JAEGER, Werner Wilhelm. Paidéia: a Formação do Homem Grego. Tradução de Artur M. Parreira. São Paulo: Ed. Martins Fontes. 1986. Pág. 226.
} 
física e social" 20 . Esse homem não terá medidas para sua busca. Mesmo sabendo que o metron o acompanha, ela não dará ouvido às Fúrias que o perseguirão. Fará o possível e o impossível para se conhecer e encontrar a sua verdadeira medida, mesmo que tenha que sair dela.

Assim, "com o seu sofrimento, o homem trágico torna-se o instrumento mais maravilhoso e mais delicado, na qual as mãos do poeta arrancam todos os tons do ailinos trágico. Para fazê-los vibrar, põe em ação todos os recursos da sua fantasia dramática. Nos dramas de Sófocles, achamos, ao contrário do que ocorre nos de Ésquilo, uma intensa elevação da ação dramática"21 . Associadas aos efeitos cênicos que os gregos conseguiam produzir em suas apresentações teatrais, esta dramaturgia consequentemente atingia uma grandiosidade inigualável potencializando a cena teatral, a tal ponto que seria impossível para um mero mortal escapar ao seu propósito dramático e emocional.

Mas foi, na grandiosa encenação dramática das tragédias nos grandes teatros da época de Sófocles, que esses seres magistralmente trágicos atingiram os seus mais altos graus de elevação e fim. Imponentes, poderosos, desgraçados, atormentados serão os novos oráculos para um povo que necessitava do grotesco para ver diante do drama humano um sentido de vida.

\footnotetext{
${ }^{20}$ JAEGER, Werner Wilhelm. Paidéia: a Formação do Homem Grego. Tradução de Artur M. Parreira. São Paulo: Ed. Martins Fontes. 1986. Pág. 230.

${ }^{21}$ JAEGER, Werner Wilhelm. Paidéia: a Formação do Homem Grego. Tradução de Artur M. Parreira. São Paulo: Ed. Martins Fontes. 1986. Pág. 230
} 
Esses homens de corpo e alma fantásticos, esses super-heróis do passado, chegavam voando em seus cavalos alados, nos seus carros de fogo, em seus navios de imensas proporções e aterrorizavam o público e os libertavam de seus pensamentos. $\mathrm{O}$ teatro grego com Sófocles transgrediu o imaginário do homem ático. Fê-lo diante da catarse $^{22}$ e na utilização do deus ex machina ${ }^{23}$, (quando necessário), sentir o terror e a piedade purificar e transcender sua alma como num êxtase dionisíaco com proporções estéticas e estatalmente direcionadas.

\footnotetext{
${ }^{22}$ Junito de Souza Brandão, em seu livro Teatro Grego: Tragédia e Comédia, (página 13), define a catarse conforme Aristóteles em sua poética da seguinte forma: "que a tragédia, pela compaixão e o terror, provoca uma catarse própria a tais emoções, isto é, relativa exclusivamente ao terror e à piedade e não a todas as paixões que carregamos em nossa alma. A matéria-prima da tragédia, como já se disse, é a mitologia. Todos os mitos são, em sua forma bruta, horríveis e, por isso mesmo atrágicos. O poeta terá pois, de introduzir, de aliviar essa matéria bruta com o terror e a piedade, para torná-los esteticamente operantes", e nesse sentido, esses hábeis artesãos do teatro tornaram-se fazer.

${ }^{23}$ Expressão latina Deus Ex Machina significa literalmente "Deus surgido da máquina" e Margot Berthold em seu livro História Mundial do Teatro, página 117 diz o seguinte: Esta "máquina voadora" era um elemento de surpresa, um dispositivo mecânico que vinha em auxilio do poeta quando este precisava resolver um conflito humano aparentemente insolúvel por intermédio do pronunciamento divino "vindo de cima". Consistia em um guindaste que fazia descer uma cesta do teto do teatro. Nesta cesta sentava-se o deus ou o herói cuja ordem fazia com que a ação dramática voltasse a correr pelas trilhas mitológicas obrigatórias quando ficava emperrada. E Sófocles utilizou esse equipamento em sua peça Filoctetes, como afirma Dario Fo em seu livro Manual Mínimo do Ator, página 264.
} 


\subsection{SÓFOCLES E PÉRICLES}

“O orgulho é o alimento do tirano; quando ele faz exagerada messe de abusos e temeridades fátuas inevitavelmente precipita-se dos píncaros no abismo mais profundo de males de onde nunca mais sairá”. 
As relações humanas na vida de Péricles e Sófocles, os fatos históricos, políticos, culturais e sociais que ocorreram na gestão política, social, econômica e teatral de ambos estão inteiramente ligadas por um padrão social instaurado no mandato do estrategista e, da mesma forma, a tragédia Édipo Rei de Sófocles contextualiza o ideal de homem que este período fomentava, tanto que "Aristóteles afirma em sua Poética que Sófocles dizia que pintava os homens como deveriam ser e que Eurípides os pintava como eram",24, e Plutarco completa "a cor que mais convém à vista é aquela que, pelo seu encanto e pelo seu tom, recreia os olhos e não os fadiga, assim como uma obra que nos agrada pelo seu encanto, não arrasta necessariamente a nossa estima pelo seu autor" 25 , ou seja, gostando ou não de Péricles como estrategista a população ateniense, talvez nem se tenha dado conta no emaranhado sutil que o general foi aos poucos traçando e instaurando uma ordem da qual ele passou a comandar sozinho.

O famoso século de ouro de Péricles, disseminado por inúmeros historiadores, teve seu preço, tanto que Plutarco nos diz o seguinte: “Tucídides para nos dar uma idéia do governo de Péricles, representa-o como uma espécie de aristocracia, à qual se dava o nome de governo democrático, mas que, de fato, era uma verdadeira monarquia na qual só o primeiro dos cidadãos exercia toda a autoridade"26, e no panteão das ilustres figuras que viveram na mesma época, a que se mais consagrou de glórias, louros e ouros foi o estrategista da eloqüência retórica, que conhecemos por Péricles. Enquanto isso outros generais, tão importantes como Péricles ou até mais,

\footnotetext{
${ }^{24}$ BRANDÃO, Junito de Souza. Teatro Grego: Tragédia e Comédia. Rio de Janeiro: Ed. Vozes, 2001, $8^{\text {a }}$ ed. Pág. 60.

${ }^{25}$ PLUTARCO. Péricles: Reformador de Atenas. Tradução e notas de Lôbo Vilela. Lisboa: Editorial Inquérito.1938. Pág. 08 e 09.

${ }^{26}$ PLUTARCO. Péricles: Reformador de Atenas. Tradução e notas de Lôbo Vilela. Lisboa: Editorial Inquérito.1938. Pág. 24.
} 
ficaram no horizonte do esquecimento, abandonados por não terem erguido grandes monumentos, mesmo que determinado no campo das reformas políticas e sociais, leis e normas das quais o próprio Péricles se utilizou.

Seguindo as informações de Plutarco, podemos encontrar, mesmo na constante defesa que o escritor alude sobre o estratega, um homem que na sua juventude temia muito o povo, que procurava evitar sua comparação e semelhança com Pisístrato e que temia ser condenado ao ostracismo por ser muito rico e ter diversos amigos influentes na democracia ateniense ${ }^{27}$. "Apesar de não ter sido ostracisado, o líder ateniense Péricles (495-429 a.C.) sofreu por diversas vezes ataques judiciais vindos de inimigos políticos, que conseguiram banir seu amigo Fídias e tentaram o mesmo com sua companheira Aspásia. O próprio Péricles por pouco não foi mandado embora da cidade e só se manteve porque era de importância ímpar para Atenas $^{928}$.

Jean-Jacques Maffre, em seu livro O Século de Péricles, divide a cidade (Polis em grego) da seguinte forma: “em regra, composta por três categorias de habitantes: os cidadãos, só eles têm direitos cívicos, os estrangeiros domiciliados (chamados de metecos) e os escravos, que não passavam de uma espécie de mercadoria

\footnotetext{
${ }^{27}$ O ostracismo foi instituído por Clistenes (510 a.C.), que, depois da queda dos Pisistrátidas, reformou a constituição de Sólon. Consistia em condenar ao exílio de dez anos os cidadãos considerados perigosos para a segurança do Estado. O termo ostracismo deriva do grego ostraka, que significa caco. Como o papel não era um material muito comum na Hélade, os atenienses usavam pedaços de cerâmicas para realizar a votação, conforme explica o filósofo Paulo Levorim, doutor em filosofia política pela Universidade de São Paulo em seu livro, A república dos antigos e a política dos modernos.São Paulo: Editora USP. 2001.

${ }^{28}$ GALLO, Rodrigo. A crueldade democrática. Leituras da história: ciência \& vida. São Paulo. Ano 1, no 4. Pág. 31, dez. 2007.
} 
animada"29, ou seja, a maioria da população. Da mesma forma, Claude Mossé afirma, "parece, todavia, que podemos distinguir dois domínios: o do pensamento especulativo, de um lado, e o do religioso, de outro. $O$ primeiro não deve ter interessado senão a uma ínfima parte dos atenienses, àqueles que compunham o séqüito de Péricles”, ${ }^{\mathbf{3 0}}$, ou seja, os que dominavam o campo político e aristocrático de Atenas. Já a outra parte, que compunham a crença religiosa, eram os que formavam a maioria do povo. Assim, pode ser que o teatro de Sófocles tenha operado a real função que o estratega desejava: imprimir um padrão de vida que permitisse a manipulação das mentes e o comportamento do homem grego no período em que ele esteve no comando, porque ir ao teatro era uma atividade cívica permitida apenas para os cidadãos gregos e nunca para escravos e metecos.

Dizer que Péricles não foi um homem astuto mediante seus inimigos políticos é ser ignorante diante do fato histórico. Tanto o foi que "após a morte de Aristides e o exílio de Temístocles, Péricles, vendo Cimone sempre ausente da Grécia em expedições militares, declarou-se a favor do partido do povo e preferiu à minoria dos ricos, a multidão dos cidadãos pobres" ${ }^{31}$, o que permitiu sua ligação e fortalecimento com os principais cidadãos de Atenas e através deles conquistar a simpatia da multidão, tendo ao seu lado o apoio do povo, evitando assim que o acusassem de pretensão à tirania. Ou seja, por trás disso tudo, um grande jogo político,

\footnotetext{
${ }^{29}$ MAFFrE, Jean-Jacques. O Século de Péricles. Portugal: Ed. Publicações Europa-América Ltda. 1990. Pág. 17.

${ }^{30}$ MOSSÉ, Claude. Atenas: a História de uma Democracia. Tradução de João Batista da Costa. Brasília: Editora Universidade de Brasília. 1997. $3^{\text {a }}$ Edição. Pág. 42.

${ }^{31}$ PLUTARCO. Péricles: Reformador de Atenas. Tradução e notas de Lôbo Vilela. Lisboa: Editorial Inquérito.1938. Pág. 19.
} 
que não difere em nada dos conluios partidários que predominam em nossa falsa democracia atual.

Assim, conquistando o povo e os aristocratas Péricles conseguiu abalar o prestigio de Cimone, seu maior rival político. Ao que parece, ter o povo ao seu lado foi sua maior façanha, afirma Plutarco:

\section{"[...] Cimone fazia diariamente grande despesa para socorrer os pobres, alimentar os cidadãos indigentes e vestir os velhos, mas Péricles, menos rico que ele, recorreu às receitas públicas, distribuindo dinheiro aos cidadãos pobres para assistirem aos espetáculos e aos tribunais, fazendo-lhes muitas concessões. A custa do dinheiro público, corrompeu a multidão e serviu-se dela para restringir o poder do Areópago, destituindo a autoridade deste conselho. $E$ desta forma fez condenar ao ostracismo o próprio Cimone. [....”32}

E foi assim, que Péricles determinou o seu comando de general sobre toda a Atenas e quem ousasse se impor no seu caminho.

Parece, a primeira vista um absurdo dizer que o teatro grego conviveu diretamente como uma teatrocracia no espaço social de Atenas, onde tragédia e manipulação de massas e teatro e política foram forças motivadoras de uma máquina administrativa aristocrática. Mas essa dirigiu o poder com um maneirismo convicto do

\footnotetext{
${ }^{32}$ PLUTARCO. Péricles: Reformador de Atenas. Tradução e notas de Lôbo Vilela. Lisboa: Editorial Inquérito.1938. Págs. 24,25 e26.
} 
que o estado necessitava. Analisando friamente o conteúdo do material que temos pesquisado, é possível que isso possa ter ocorrido e talvez em dimensões muito maiores.

A qual caminho nos leva esse posicionamento com relação a Péricles e o Estado democrático de Atenas do século V a.C., até a tragédia de Sófocles? Evidentemente que não podemos afirmar, como um grego que viveu naquela época, se realmente Sófocles tomou partido ou não perante o posicionamento de seu amigo Péricles, mas diversos textos de outros autores e pesquisadores nos indicam que pode ter sido possível.

Quando contextualizamos esses textos e percebemos a sinergia existente entre eles, nossa orientação foi seguir um curso comparativo de um homem com o outro. $\mathrm{Ou}$ seja, a atitude da encenação teatral, do texto trágico e a relação íntima que Sófocles teve com Péricles podem caracterizar e evidenciar influências do Estado na postura de Sófocles quanto ao conteúdo de suas peças.

Assim, nossa dissertação sofre um recorte sincrônico sobre as figuras de Péricles e Sófocles que, durante a pesquisa realizada evidencia que ambos estiveram estreitamente ligados como amigos, estrategas e homens com uma vida pública intimamente relacionados à formação cultural, social e política do homem grego de seus períodos.

Esse fato nos abriu uma porta para a visão político-cultural que poderia estar associada na real utilização do teatro grego como forma de manipulação de massas de suas épocas, já que o estrategista detinha um poder político fundamental nas castas 
sociais gregas, assim como o teatrólogo detinha um poder sacerdotal sobre estas mesmas castas sociais. Ou seja, a política e o teatro podem ter se unido para a construção de uma encenação que transformasse idéias em atitudes.

Werner W. Jaeger em sua Paidéia: a Formação do Homem Grego diz que:

"[...] O estado fomentava estes concursos por meio de prêmios e representações, para orientá-los na sua carreira e, ao mesmo tempo, estimulá-los. Independentemente da permanência da tradição profissional em qualquer arte, e principalmente na arte grega, era inevitável que esta comparação viva, ano após ano, criasse para aquela nova forma de arte um "controle" espiritual e social permanente. Isto não afetava em nada a liberdade artística, mas tornava o espírito público extraordinariamente vigilante em face de qualquer diminuição da grande herança e contra qualquer perda da profundidade e da força da ação. $[. . .]^{9333}$

Assim o Estado mantinha seu estatus quo utilizando, em específico, as encenações teatrais das grandes tragédias.

${ }^{33}$ JAEGER, Werner Wilhelm. Paidéia: a Formação do Homem Grego. Tradução de Artur M. Parreira. São Paulo: Ed. Martins Fontes. 1986. Pág. 219. 
Como já dissemos anteriormente, Sófocles criou as personagens mais trágicas que o teatro grego já viu, e nessa encruzilhada de pensamentos e atitudes vamos nos deparar com as duas figuras predominantes da época. Um tragediógrafo que queria, na eloqüência da sua arte teatral realizar grandes trabalhos e um estrategista que descobriu nessa arte uma importância que poderia fortalecer suas idéias "imperialistas".

O que se aponta neste capítulo sobre o estrategista não é o que ele fez, mas como realizou tais feitos. Plutarco praticamente o eleva a condição de divindade, mas em seus textos fica evidente outra possibilidade de leitura, como no caso do exílio de Tucídides, filho de Milésio, onde "sua rivalidade com Tucídides chegava a tal extremo que só podia terminar com a proscrição de um ou outro, ele conseguiu fazê-lo exilar e destruiu assim a facção inimiga. $O$ exílio de Tucídides fez cessar as dissensões, restabeleceu a união e a paz na cidade e tornou Péricles senhor absoluto de Atenas cujos negócios dirigia pessoalmente ${ }^{\text {34 }}$. Esse relato que Plutarco acentua a relação manipuladora de um imperialista revestido de estratega, o que nos permite dizer que Péricles abusou da máquina administrativa do Estado para exercer um ideal de conduta sobre a mentalidade do homem grego.

Não podemos utilizar a palavra imperador para Péricles, mas podemos investigar a sua atitude imperialista sobre a cidade de Atenas que permitiu o domínio dos seus associados. O que vale dizer que a palavra imperador deriva do latim imperator, ou seja,

\footnotetext{
${ }^{34}$ PLUTARCO. Péricles: Reformador de Atenas. Tradução e notas de Lôbo Vilela. Lisboa: Editorial Inquérito.1938. pág. 40.
} 
alguém que se prepara contra e que tem o poder sobre esse algo. A pessoa que detém esse poder pode ser um comandante, magistrado ou estrategista. A palavra estrategista tem sua origem na raiz da palavra stratègós (de stratos, exército, e ago, liderança, ou comando que seria a mesma tradução para a "arte do general". Para os gregos, o estrategista era também um comandante ou general, e toda essa contextualização de palavras vem confirmar a atitude imperialista de Péricles, já que ele era um general e exercia a supremacia sobre seu povo.

Estratégia é a arte da dialética da vontade de um valendo-se da força ou da persuasão para atingir determinado objetivo e Péricles não mediu esforços para isso. Tanto que "tinha à sua disposição as receitas públicas, os exércitos e as frotas, as ilhas e o mar. Exercia sozinho este vasto domínio que, estendendo-se pela Grécia e pelos bárbaros, era sustentado ainda pela obediência das nações submetidas",35. Assim, exercia um padrão de administração que podemos dizer "império Ateniense" movido por um padrão que Péricles sustentou.

Essa atitude empregada no seu mandato "alternava-se entre a esperança e o temor, como duplo leme: um sustentava os ímpetos da multidão, e o outro a reanimava quando estava desalentada. Mostrou assim que a eloqüiência, como diz Platão, é a arte de conduzir os espíritos; que sua principal função consiste em manejar, a propósito, as paixões e tendência dos homens, como cordas que pedem

\footnotetext{
${ }^{35}$ PLUTARCO. Péricles: Reformador de Atenas. Tradução e notas de Lôbo Vilela. Lisboa: Editorial Inquérito.1938. pág. 40.
} 
para ser tocadas por hábeis mãos" ${ }^{\text {36, }}$ o que caracteriza o poder de manipulação que Péricles detinha em seu poder.

A democracia e participação política ateniense eram formadas por cidadãos atenienses adultos (filhos de pai e mãe nascidos em Atenas), o que correspondia a uma minoria, pois eram excluídos os estrangeiros (metecos), escravos e mulheres, que representavam a maioria, assim o direito de decisões políticas tomadas em assembléias restringia a uma minoria, o povo autenticamente grego residente na cidade. Então, podemos dizer que o padrão democrático utilizado pelos gregos não pode se caracterizar como o melhor de todos, pois quem decidia a vida social em Atenas não passava de uma pequena parcela da população.

Em seu livro Atenas: a História de uma Democracia, Claude Mossé confirma: "um cidadão ateniense jamais poderia dever nada ao tesouro público, tinha que ser legitimamente casado, possuir bens em Atenas, ter cumprido seus deveres para com seu pai e sua mãe, ter feito expedições militares, ser contra Esparta, gostar, amar e honrar Atenas e nunca ter cometido crime contra a cidade, 37

É nesse padrão de homem grego, da medida perfeita, que Péricles e Sófocles se encontram na tragédia do Rei Édipo, como sendo Édipo o elemento central do mito, e

\footnotetext{
${ }^{36}$ PLUTARCO. Péricles: Reformador de Atenas. Tradução e notas de Lôbo Vilela. Lisboa: Editorial Inquérito.1938. pág. 41 e 42.

${ }^{37}$ MOSSÉ, Claude. Atenas: a História de uma Democracia. Tradução de João Batista da Costa. Brasília: Editora Universidade de Brasília. 1997. $3^{\text {a }}$ Ed. pág. 39.
} 
personagem questionadora do valor do homem e dos deuses, onde oráculos e Tirésias estão sempre observando à distância, polindo suas atitudes no livre arbítrio que ele possui. Assim, acabam encontrando nessa personagem mitológica a postura e o ideal do homem e do herói que deveria habitar o centro da sociedade grega.

É desta forma que o mito de Édipo aflora numa Atenas que resplandece entre os povos gregos. É este ser admirável e extraordinário transformado e recriado por Sófocles no teatro que reavivara a imagem dos de tempos de outrora, onde nobreza, virtude, prudência, bravura e honra representavam o escol de uma raça no seu mais alto grau da arete na formação do homem ateniense do século V a.C.

Benard Knox em seu livro Édipo em Tebas, complementa:

"[...] Esta combinação de ação imediata baseada em reflexão inteligente, que produz sucesso que, por sua vez, dá origem a uma autoconfiança justificada é, obviamente, a marca de individuo superior. Todavia, tal indivíduo, numa sociedade, pode fazer o bem ou, como a Atenas do século $\mathrm{V}$ descobriria às suas próprias custas, causar grande dano. Um homem assim poderia ser tanto um Péricles como um Alcibíades. No caso de Édipo, estes grandes dons são controlados por um patriotismo profundo e um senso de responsabilidade para com a 
comunidade: ele é apresentado, nas cenas de abertura, como o governante ideal. [... $]^{933}$

Seguindo esse pensamento, nossa dissertação segue em direção a Sófocles e seu Édipo Rei, afinal, a personagem protagonista da tragédia incorreu justamente nas falhas que o estrategista sempre desviou de seu caminho. Não seria o Édipo de Sófocles a imagem deteriorada do homem grego que Péricles sempre evitou? Pode ser que seja, afinal, um encenador como Sófocles conseguiria, sem muito esforço, criar uma personagem que causasse todo tipo de assombro na multidão que assistia ao espetáculo, levando o público à cartase imediata.

Mas como Sófocles realizaria tal feito? Como pode transformar o mito em algo tão fenomenal? Provavelmente ele tenha adulterado algum dado do mito, ou seja, tomou da licença poética, para manipular fatos de uma cultura oral em prol da política vigente em seu período.

E isso é possível, a corrupção sempre existiu, ela faz parte dos desejos humanos. Olga Rinne, em seu livro Medéia: o Direito à Íra e ao Ciúme, cita um trecho em que "segundo a observação de um escolista, que parece uma anedota, os coríntios teriam subornado Eurípedes por quinze talentos de prata, para que alterasse a

\footnotetext{
${ }^{38}$ KNOX, Bernard. Édipo em Tebas: o Herói Trágico de Sófocles e seu Tempo. Tradução de Margarida Goldsztyn. São Paulo: Ed. Perspectiva. 2002. Pág. 17.
} 
história dos assassínios dos filhos de Medéia" ${ }^{39}$, para que transformasse Medéia nesse ser repulsivo e destituída de caráter humano que a maioria das pessoas enxergam sem questionar um erro mínimo de Jasão.

Pode ser que tenha realmente acontecido: afinal, teria a tragédia de Eurípedes a mesma força se Medéia não fosse apresentada como infanticida? E para nossa dissertação: teria a mesma força dramática a tragédia do rei Édipo se Jocasta não fosse sua mãe e sim sua madrasta?

Então, com muito cuidado, procurando esmiuçar estas relações que fogem da escrita histórica, que acontecem entre quatro paredes dentro de um palácio, de uma sala, ou até mesmo durante uma caminhada, vasculhamos o teor de cada texto estudado para contextualizar o que poderia ter ocorrido.

Podemos dizer, numa análise especulativa do entendimento que temos sobre o homem e suas atitudes, que o homem perfeito de Péricles nasceu em Édipo, entre as inúmeras páginas da tragédia escrita por Sófocles, para escoar no palco, que nesta época já não tinha o mesmo valor sagrado de tempos anteriores. E o que evidencia essa mescla teatro-politica-religião é a própria transformação do homem grego que gradativamente

\footnotetext{
${ }^{39}$ RINNE, Olga. Medéia: o Direito à Ira e ao Ciúme. Tradução de Margit Martincic e Daniel Camarinha da Silva. São Paulo: Editora Cultrix. 1988. pág. 11.
} 
vai deteriorando seus valores em prol de ajeitamentos e acertos políticos que se tornaram necessários.

É evidente que não podemos comparar essa transformação de supostos partidarismos na mesma intensidade política e partidária dos dias de hoje, mas é nesse minúsculo conjunto de confederações de polis e genos que a máquina cerebral e desprezível do homem traz o cerne da ganância e da crueldade, no qual vai enraizar-se por toda a Grécia penetrando no mais singelo lar do homem tipicamente grego.

Feitos maravilhosos muitos homens fizeram. De construções gigantescas em ouro, marfim e mármore o planeta está repleto. Esse atributo dado a Péricles deve se estender aos inúmeros reis, imperadores, faraós e sacerdotes de diversos povos e tribos do mundo. Cada um com sua peculiaridade teve o seu papel histórico, arquitetônico, político, econômico e social utilizando cada um seu meio e forma.

Como nossa análise esta centrada nas personagens de Édipo e Jocasta de Sófocles e suas relações com a personagem mítica e heróica de Édipo, o que buscamos esclarecer não é o somente o que fizeram e realizaram através da arte teatral grega, mas como utilizaram essa fabulosa criação humana na reconstrução do mito e do herói tebano no seio da sociedade ateniense. 
O MITO: ÉDIPO

“Vede bem, habitantes de Tebas, meus concidadãos!

Este é Édipo, decifrador dos enigmas famosos; ele foi um senhor poderoso e por certo o invejastes em seus dias passados de prosperidade invulgar. Em que abismos de imensa desdita ele agora caiu! Sendo assim, até o dia fatal de cerrarmos os olhos não devemos dizer que um mortal foi feliz de verdade antes dele cruzar as fronteiras da vida inconstante sem jamais ter provado o sabor de qualquer sofrimento!" (Sófocles - Édipo Rei: Corifeu - versos 1802 aos 1810) 
Elaborar mais um, dentre tantos trabalhos já existentes sobre o mito do Édipo Rei de Sófocles, é ser como um arqueólogo que, ao escavar os campos da Grécia, encontra milhões de cacos de cerâmicas e procura juntá-los num gigantesco mosaico para compor mais um quadro com inúmeros enigmas que nos acompanham até hoje. Afinal, seu mito foi e ainda é interpretado das mais diversas formas por inúmeros estudiosos das mais diversas áreas de pesquisa cientifica do mundo.

Jean-Pierre Vernant, ao estudar o complexo de Édipo sobre a ótica da psicologia histórica, diz o seguinte:

\author{
"[...] O destino de Édipo é, de certa forma, o nosso, é que \\ carregamos em nós a mesma maldição que o oráculo \\ pronunciou contra ele. Matando seu pai, esposando sua \\ mãe, ele realiza o desejo de nossa infância, que nos \\ esforçamos para esquecer. A tragédia é, portanto, em \\ tudo, comparável a uma psicanálise: levantando o véu \\ que dissimula a Édipo seu rosto de parricida, ela nos \\ revela a nós mesmos. [...]"40
}

Analisando a aventura de nosso herói torna-se impossível desvencilhar o tipo heróico de homem que Sófocles apresenta-nos na personagem de Édipo dos nossos

\footnotetext{
${ }^{40}$ VERNANT, Jean-Pierre; VIDAL-NAQUET, Pierre. Mito e Tragédia na Grécia Antiga I e II. Tradução de Anna Lia A. de Almeida Prado, Filomena Yoshie Hirata Garcia e Maria da Conceição M. Cavalcante. São Paulo: Ed. Perspectiva. 1999. Pág. 54.
} 
complexos "de fulano de tal" da infância, assim como não podemos afirmar que possa ser exatamente de Édipo.

Dizer que uma magnífica construção humana como a do novo rei de Tebas é apenas uma obra poética e literária é diminuir o próprio conteúdo da tragédia e reduzir a capacidade de compreensão que o sábio Sófocles conhecia e dominava sobre o homem de seu tempo e suas raízes heróicas. Assim, Bernard Knox em seu livro Édipo em Tebas complementa:

“[...] As decisões e ações de Édipo são o fator causal no
enredo da tragédia e constituem a expressão do seu
caráter. Édipo não é um homem comum, na verdade é
extraordinário: começou com nada além de sua
sagacidade e energia, tornando-se o despótico e amado
governante da cidade à qual chegou como exilado sem
lar. Seu caráter multifacetado e sutilmente complexo, no
entanto, tem uma consistência maravilhosa. Édipo é,
certamente, o maior indivíduo particular na tragédia
grega. [...]" 41

O que nos leva, antes de vasculhar o mito, entender melhor a origem de um herói como Édipo, que agrega valores e virtudes específicas que compõem sua personalidade humana. Valores fundamentados num tipo de nobreza que Werner Jaeger exemplifica da seguinte forma:

\footnotetext{
${ }^{41}$ KNOX, Bernard. Édipo em Tebas: o Herói Trágico de Sófocles e seu Tempo. Tradução de Margarida Goldsztyn. São Paulo: Ed. Perspectiva. 2002. Pág. 10.
} 


\section{“[...] A nobreza é a fonte do processo espiritual pelo qual nasce e se desenvolve a formação de uma nação. A história da formação grega - o aparecimento da personalidade nacional helênica, tão importante para o mundo inteiro - começa no mundo aristocrático da Grécia primitiva com o nascimento de um ideal definido de homem superior, ao qual aspira o escol da raça. $[\ldots]^{9,42}$.}

É desta nobreza do mais alto nível de educação e conduta, vigor e heroísmo guerreiro que descende Édipo.

Para clarear a formação da personalidade de Édipo e originalmente transformá-lo num mito seria necessário que ele passasse por todas as fazes que um herói grego como Orestes, Ájax, Aquiles, entre outros, também passaram. Assim, o princípio da virtude e o conceito de arete estão impregnados na construção humana da personagem de Sófocles.

Seria fundamental para sua época que Sófocles criasse uma personagem virtuosa, capaz de atender e inspirar os desejos de uma população que viria em Édipo o repudio e ao mesmo tempo a identificação do seu eu. Em sua envergadura heróica o personagem inspira no espectador suas mais altas qualidades, de um homem dotado de princípios, excelência humana e superioridade absoluta.

Além do mito elaborado e adequado de sua concepção usual originária e impregnada na sociedade, Édipo de Sófocles é a imagem perfeita do ideal de homem que

\footnotetext{
${ }^{42}$ JAEGER, Werner Wilhelm. Paidéia: a Formação do Homem Grego. Tradução de Artur M. Parreira. São Paulo: Ed. Martins Fontes. 1986. Pág. 18.
} 
uma Atenas necessitava no período de Péricles. Um homem prudente, astuto, nobre, viril, honrado, ágil, heróico, mas, também falho, trágico e esfacelado para servir de modelo para à sociedade ateniense do século V a.C.

Então, para não passarmos a frente dos estudos de Freud, como quem ignorasse sua interpretação sobre o mito, utilizamos a análise do historiador Bernard Knox que diz:

"[...] Segundo Sigmund Freud Oedipus Rex é uma tragédia de destino: seu efeito trágico depende do conflito entre a vontade todo-poderosa dos deuses e os esforços vãos de seres humanos ameaçados pelo desastre; a resignação à vontade divina e a percepção da impotência pessoal é a lição que o espectador profundamente comovido deve aprender da tragédia. Autores modernos buscaram, por conseguinte, alcançar um efeito trágico similar expressando o mesmo conflito em histórias de sua própria invenção [...]. Apreciadores de teatro, contudo, parecem não se comover [...]. As tragédias de destino modernas não conseguiram causar efeito. Se Oedipus Rex é capaz de emocionar o leitor ou o espectador moderno tanto quanto comoveu os gregos, a única explicação possível é que o efeito da tragédia grega não depende do conflito entre o destino e a vontade humana, mas da natureza peculiar do material por meio do qual este conflito é revelado. Deve existir dentro de nós uma voz pronta para reconhecer a força convincente do destino em Oedipus, ao passo que somos capazes de condenar as situações que ocorrem em Die Ahnfrau ou 
outras tragédias de destino como invenções arbitrárias [...] este destino [de Édipo] nos emociona somente porque poderia ter sido o nosso, porque o oráculo colocou diante de nós, antes de nosso nascimento, a mesma maldição que pairava sobre ele. "É possível" que todos nós estivéssemos destinados a dirigir nossos primeiros impulsos sexuais às nossas mães e nossos primeiros impulsos de ódio e violência contra nossos pais; nossos sonhos nos convencem de que isso realmente é verdade. $[\ldots]^{9,43}$.

Conceituar ou cristalizar a tragédia Édipo Rei de Sófocles apenas no campo onírico dos nossos desejos, é depreciar o trabalho do autor e renegar ao campo do esquecimento belíssimas obras de outros escritores trágicos, tão importante quanto Sófocles. Sobre esse ponto de vista, Jean-Pierre Vernant acrescenta:

"[...] Como Freud pode esquecer que existem outras tragédias gregas, além do Édipo-Rei, e que, entre aquelas que nos foram conservadas de Ésquilo, de Sófocles e de Eurípides, a quase-totalidade nada tem a ver com os sonhos edipianos? Deve-se dizer que são peças ruins, que não comportam efeito trágico? Se os antigos as admiravam, se o público moderno é por algumas delas perturbado, como pelo Édipo-Rei, é porque a tragédia

${ }^{43}$ KNOX, Bernard. Édipo em Tebas: o Herói Trágico de Sófocles e seu Tempo. Tradução de Margarida Goldsztyn. São Paulo: Ed. Perspectiva. 2002. Págs. 02 e 03. 
não está ligada a um tipo particular de sonho, porque o efeito trágico não reside em uma matéria, mesmo onírica, mas na maneira de dar forma à matéria, para fazer sentir as contradições que dilaceram o mundo divino, o universo social e político, o domínio dos valores, e fazer assim aparecer o homem como um thâ̂ma, um deinón, uma espécie de monstro incompreensível e desconcertante, ao mesmo tempo agente e paciente, culpado e inocente, dominando toda a natureza por seu espírito industrioso e incapaz de governar-se, lúcido e cegado por um delírio enviado pelos deuses [...]"44

No entanto, nossa dissertação sobre o mito não penetra nos universos das teorias psicanalíticas que envolvem o complexo de Édipo elaborado por Freud, mas se agrega aos estudos culturais, históricos, sociais e políticos que permeiam o imaginário do povo grego e suas relações intrínsecas com a valorização ou deterioração desse mito ao longo dos séculos e das mudanças de valores e costumes.

Assim, cada fragmento coletado vai criando uma nova releitura do mito que nos possibilita dizer que: ou Jocasta soube o tempo todo que o homem com quem estava se casando era Édipo, ou por questões sociais teve que unir-se à Édipo, mesmo contra sua vontade.

\footnotetext{
${ }^{44}$ VERNANT, Jean-Pierre; VIDAL-NAQUET, Pierre. Mito e Tragédia na Grécia Antiga I e II. Tradução de Anna Lia A. de Almeida Prado, Filomena Yoshie Hirata Garcia e Maria da Conceição M. Cavalcante. São Paulo: Ed. Perspectiva. 1999. Pág. 57
} 
Seja uma ou outra a versão real, o que nos importa no contexto do texto de Sófocles, engessado pela escrita e por sua época, pressupõe que a representação da peça passou a seguir um novo roteiro, refazendo do mito original uma nova história causando muito mais impressão no público presente. E é desta forma que Sófocles segue minuciosamente os padrões políticos e sociais que a época exigia.

Esse Édipo claudicante, mitológico e enigmático é uma obra prima da tragédia grega. Portanto, elaborar um capítulo sobre o mito de Édipo, rei de Tebas no período heróico da Grécia antiga, que, ao retornar à Tebas seguiu o caminho que vai da cidade de Corinto até Tebas e de Tebas até Atenas e torna-se o mito imortalizado na tragédia de Sófocles, será um grande caminho a ser percorrido por nós na construção desta dissertação.

Assim, para entender o caminho do jovem Édipo-adotivo que recebe um insulto de um bêbado que o acusa de filho adotivo, durante uma festa na cidade de Corinto, onde até então vivia como príncipe, filho de Pôlibo e Mérope será necessário trilhar o caminho que o levou até Corinto e posteriormente ser, o rei de Tebas.

Da mesma forma que chega a Corinto, filho do acaso e do desprezo, ele irá partir desse lar querido que o criou e educou. Esse Édipo-fugitivo e claudicante, que no dia seguinte vai até o oráculo de Delfos para ter certeza de sua verdadeira origem e descobre que traz consigo uma maldição, foge sem rumo certo, não retornando jamais para Corinto para levar sobre suas costas a maldição que pesa sobre ele. 
Um Édipo-maldição, que após saber que o oráculo prevê que ele matará seu pai e se unirá a sua mãe, procura evitar seu vaticínio através da fuga, desaparecendo pelas estradas tortuosas da Grécia, sem saber para onde ir. No caminho da fuga encontra seu fim no arrebatamento e no furor de sua desventura acaba por se tornar um assassino de viajantes que seguiam em sentido contrário a estrada que seguia. Mal sabe o jovem, acabara de matar seu verdadeiro pai.

Então, esse Édipo-adivinho chega a Tebas, decifra o enigma da Esfinge e torna-se o salvador da cidade, fulgurando como um filho enviado pelos deuses para realizar tamanha façanha, tornando-se o mais famoso herói tebano existente em toda história da cidade. Assim, o Édipo-herói, que após ter eliminado o monstro que castigava a cidade, torna-se, diante do povo tebano, o herói salvador da cidade, o filho enviado para livrar a cidade de todos os males.

Da saída impensada de Corinto até sua chegada em Tebas, o jovem indigente torna-se o Édipo-Rei. Ganha como prêmio, pela sua capacidade de adivinhar e decifrar enigmas, o trono de Tebas e junto com ele a mão da rainha, irmã de Creonte e viúva do antigo rei Laio. Recebe-a como esposa, pois assim seria o combinado para quem fosse o salvador.

No reinado é gerada a prole do nosso herói. Jovem, moço e viril, contrai núpcias com a rainha Jocasta, ex-esposa de Laio, deixa para o trono dois filhos homens Etéocles e Polinices, e duas filhas, Antígona e Ismene, possibilitando, assim, a continuidade de um rei assumir o trono da cidade após sua morte. 
Mas o Édipo-salvador é o Édipo-peste, que, após ter passado vários anos reinando na cidade é tomado de surpresa por uma violenta e avassaladora peste. Segundo o oráculo de Delfos, foi enviada pelos deuses para punir a cidade que abriga o assassino de Laio. Então, diante de tal informação, o Rei Édipo proclama que fará de tudo para descobrir onde está escondido esse assassino e decreta que ele será expulso da cidade.

O rei posto será o rei deposto. Então, o rei decidido a encontrar o assassino não mede conseqüências para descobrir onde está escondido esse ser maléfico, capaz de matar um rei. Assim nosso herói se descobre o Édipo-parricida, que no decorrer da busca pelo assassino se autodescobre o matador de Laio, fato acontecido numa encruzilhada de Delfos e Dália, na direção da estrada que chegava a Tebas.

Como se não bastasse, o decifrador de enigmas se descobre no maior de seus horrores, o Édipo-incestuoso. Sem saber que Jocasta seria sua mãe, uniu-se em matrimônio com a rainha a partir do momento em que a recebeu como esposa (segundo a tragédia de Sófocles, Jocasta é a esposa de Laio, portanto pai de Édipo).

Então, novamente desgraçado, o Édipo-exilado, que na busca frenética para ter certeza da sua verdadeira origem precipita-se em inúmeras situações até encontrar a verdadeira resposta, tendo como fim a esposa morta, a cegueira de seus olhos e mais uma vez o exílio e o desterro como companheiros. Somente assim poderá ser o Édiposalvador, que, perante sua virtude e honra implacáveis, toma como autopunição ou purificação de seus atos inadmissíveis, a carga dos males que assolaram Tebas. Parte, 
cego e indigente, para o distrito de Colono, acompanhado por sua filha Antígona, promovendo assim a aniquilação da peste na cidade, levando o fardo da dor até o bosque das Eumênides, onde será purificado do seu sofrimento.

Desta forma, conseguimos traçar um caminho, mesmo descartados os momentos em que ele se deslocou por alguma viela entre Corinto e Tebas. Chegarmos então à versão mais conhecida do mito através do trágico Sófocles, com sua primeira representação no ano de 430 a.C. em Atenas (data aproximada), no teatro de Dioniso.

Quando, no início deste capítulo incluímos diversos adjetivos para a figura mítica de Édipo, nossa intenção fora analisar passo a passo as variantes do mito e correlacionálas com a que foi escolhida por Sófocles para tragédia, Édipo Rei, que chegou até nossos dias.

Decodificando a origem do mito, que provém do nascimento, maldição e exposição da criança não desejada, até seu exílio de Tebas e acolhimento em Colono, colônia de Atenas, desvenda-se todo o mistério do homem impuro em purificador após sua morte, conforme a peça Édipo em Colono de Sófocles, representada pela primeira vez no ano de 401 a.C. em Atenas. Assim, conseguimos esmiuçar o mito e estabelecer uma possível ordem do mito nas suas diversas variantes e situações que envolvem a figura de Édipo.

Laio, herdeiro do trono de Tebas e de algumas mazelas de seus antepassados Cadmo, que matou o dragão de Ares, e Lábdaco, que fez afronta ao deus Dioniso, 
acabou por cometer grave harmatia (falha trágica) na corte do rei Pélops. Ainda muito jovem, perdeu seu pai, que foi destroçado pela fúria das bacantes e por ser oposto a introdução do culto de Dioniso em Tebas, morre prematuramente. Seu tio Lico assume o trono, mas é assassinado por Anfião e Zeto. Laio, herdeiro original do trono, para não ser morto pelas disputas acirradas sobre o trono de Tebas, foge e pede asilo na corte do rei Pélops, onde conhece o belo Crisipo, filho do rei. Rapta o jovem e mantém relação homossexual com o rapaz. Dessa atitude e cometendo um amor contra naturam, Laio ofende Hera, deusa dos amores legítimos, que apóia a maldição lançada pelo rei Pélops, o que teria, talvez, aumentado a maldição dos Labdácidas, iniciadas com Cadmo e Lábdaco.

Numa análise especulativa, provavelmente é desta maldição que surge o fato de Laio não poder ter filhos, como adverte "por três vezes, em Pito, seu santuário profético, centro do mundo, Apolo revela a Laio que ele deveria morrer sem filhos, se quisesse salvar a cidade (Tebas)" ${ }^{95}$. Laio casa-se com Jocasta (segundo a tragédia de Sófocles) e com ela tem um filho. Passados três dias de vida, Laio manda seu fiel pastor Menetes levar a criança até o monte Citéron e matá-la. No entanto, quando o pastor chega ao local, não tem coragem de matar a criança e traspassa seus tornozelos com uma corda, prende-o num galho de uma árvore para que possa a natureza se incumbir de sua morte. Porém, passando por ali o pastor Forbas da cidade de Corinto, vê a criança, desamarra seus tornozelos, cuida de seus ferimentos e leva-a para seu rei,

\footnotetext{
${ }^{45}$ BRANDÃO, Junito de Souza. Mitologia Grega. Rio de Janeiro: Ed. Vozes, 1993, 5ª ed., Vol. III. Pág. 241.
} 
Pôlibo, que não podia ter filhos. Assim, Édipo torna-se filho "adotivo" de Pôlibo e Mérope, o rei e a rainha de Corinto.

Na versão traduzida da tragédia Édipo Rei, diretamente do grego, por Mário da Gama Kury, o pastor de Laio encontra-se com o pastor de Pôlibo e lhe doa a criança. Édipo já está com os pés traspassados, ele cuida dos ferimentos e depois leva a criança para os reis de Corinto, onde Édipo é criado e educado por Pôlibo e Mérope, até atingir a maioridade. No outro dia, procura o oráculo de Delfos e descobre que carrega consigo a maldição de matar seu pai e casar-se com sua mãe.

O oráculo não profetiza nada sobre ele ser ou não filho adotivo, ao contrário, no momento que o vê lança a premonição que ele mataria o pai e se casaria com a mãe. Édipo, desesperado, foge para longe dos pais. Mas não seria correto, ele, sabendo do oráculo, retornar para Corinto? Édipo é um homem inteligente, porque fugir? O mais lógico seria contar aos pais o que estava acontecendo. Mas não, ele teria que fugir. Ou seja, Sófocles o está diretamente associando a figura do homem comum, para posteriormente ele se tornar um herói.

Existem outras variantes sobre sua fuga mas, seguindo o texto de Sófocles, o caminho só poderia ser esse. Ou seja, o momento em que nosso jovem terá que passar por outras provações e vencê-las para ser inserido no universo mitológico dos grandes 
heróis e consequentemente tornar-se a figura que representará o grande tirano de Tebas, não apenas um simples rei.

Analisando historicamente a problemática da criança exposta entendemos que, para os gregos, assim que um filho homem nascia, existia uma série de rituais iniciáticos para que a criança passasse a fazer parte daquele genos e tornar-se integrante real e consangüíneo daquela família. A turbulenta vinda de nosso herói para o seio familiar de Laio, mediante as pesquisas históricas existentes, não existiu. O que nos permite dizer que, não passando pelos rituais da família, Édipo não se tornou membro oficial do geno, descaracterizando-o como filho. Daí duvidarmos que Édipo fora simplesmente filho adotivo de Pôlibo e Mérope, afinal, três dias após seu nascimento ele foi exposto no monte Citéron e em seguida doado para outra família. Todo o tempo que envolveu do nascimento de Édipo até sua chegada como "filho adotivo" em Corinto, determina a negação de qualquer forma de associação paterna de Laio com Édipo e sim com Pôlibo.

Nesse ponto, a tragédia de Sófocles norteia nosso propósito quando Jocasta, na tentativa de esclarecer a situação perturbadora do marido, diz:

\section{Jocasta:}

"[...] Vivia nosso filho seu terceiro dia quando rei Laio lhe amarrou os tornozelos e o pôs em mãos de estranhos, que o lançaram logo 


\section{em precipícios da montanha inacessível [...]”46.}

O que o torna apenas filho biológico de Laio e Jocasta, já que a criança não passou pelos ritos iniciáticos que deveria ter passado.

Entre os gregos e diversos povos da humanidade os ritos de passagem após o nascimento da criança e até um determinado tempo depois de seu nascimento são tão importantes quanto o próprio nascimento. Recheados de banhos, benzimentos, purificações para livrá-la de qualquer tipo de mácula, mancha ou sujeira, a criança passará por uma série de rituais até poder receber a proteção paterna e fazer parte daquela família.

O primeiro banho, por exemplo, era para testar a resistência da criança, diz Maria Beatriz Borba Florenzano:

“[...] Em Esparta, onde havia uma preocupação muito grande com a criação apenas dos mais fortes e vigorosos, as mulheres "não lavavam os recém-nascidos com água, mas com vinho [...] Os doentios e sujeitos à epilepsia morrem de convulsões sob o efeito do vinho puro, enquanto os sadios dele recebem uma melhor tempera e

\footnotetext{
${ }^{46}$ SÓFOCLES. Édipo Rei. Tradução do grego Mario da Gama Kury. Rio de Janeiro: Ed. Jorge Zahar. 2001,
} $5^{\text {a }}$ ed. Pág. 54, versos 858-861. 
maior vigor". Em outros lugares, as criancinhas eram testadas com água gelada e até mesmo com urina. [...]"47

No caso do nascimento de Édipo é até possível que ele tenha passado por essa primeira etapa, testando sua resistência. O que se enquadra no mitologema e saga dos heróis. Quanto a sua participação no seio familiar de Laio, isso não ocorreu e a autora completa:

"[...] De acordo com referências esparsas nos textos antigos, nos dias que se seguiam ao nascimento executava-se uma série de ritos privativos destinados a integrar a criança na casa paterna, chamada de oikos. 0 primeiro desses ritos realizava-se no quinto ou no sétimo dia após o nascimento. Essa festa começava por um sacrifício de um animal às divindades familiares, seguido por um ritual no qual o pai da criança, nu, a carregava, coberta de amuletos mágicos contra o mau-olhado, em torno do altar familiar. Água lustral destinada à purificação era derramada sobre o bebê e fórmulas mágicas eram recitadas. Nesse momento, o pai, autoridade máxima da família, reconhecia a criança como seu filho e aceitava-a no seio da família. Tornava-se assim, o quírios da criança, isto é, o seu senhor, até que ela se tornasse independente, no caso dos meninos, ou

\footnotetext{
${ }^{47}$ BORBA FLORENZANO, Maria Beatriz. Nascer, Viver e Morrer na Grécia Antiga. São Paulo: Atual Editora, 1996. Págs. 14 e 15.
} 
passasse para a autoridade de outro quírios, no caso das meninas.[...]" $]^{\sharp 8}$

No caso de Édipo, o seu quírios não existiu, já que o ritual se completava aos sete dias após o nascimento da criança. Assim, a mácula continuaria com ele, pois não recebeu o banho da água lustral que purificaria seu corpo e espírito. Ou seja, Édipo, será um nome posterior, que provavelmente recebeu em Corinto, pois fora exposto sem nome e identidade, ou seja, o mito da criança exposta.

De acordo com a Professora e Doutora Maria Beatriz Borba Florenzano em seu livro Nascer, Viver e Morrer na Grécia Antiga, diz:

“[...] A prática de exposição de recém-nascidos era comum entre os gregos. Se um pai decidia que não iria criar uma criança, quando esta nascia, era colocada em um pote de argila e colocada no campo, para morrer de fome, frio ou devorada pelos animais a exposição" [...] e acrescenta, "[...] em segundo lugar, tudo indica, a exposição de crianças era empregada geralmente em casos de bebês defeituosos ou ilegítimos. Estes últimos eram entendidos como aqueles nascidos de uniões não

\footnotetext{
${ }^{48}$ BORBA FLORENZANO, Maria Beatriz. Nascer, Viver e Morrer na Grécia Antiga. São Paulo: Atual Editora, 1996. Pág. 15.
} 


\section{aceitas pela comunidade, uniões fora do casamento. $[. . .]^{9949}$}

No caso da exposição de Édipo, até agora os textos estudados apontam para a maldição provinda da Pítia do oráculo de Delfos, que impôs a Laio jamais ter filhos e, se acaso o tivesse, e este fosse um filho homem, o mesmo quando adulto mataria o pai e se casaria com a mãe.

Surge então, uma nova pergunta: será que Édipo nasceu com problemas físicos nos pés e daí sua exposição? Não sabemos. Uma, entre tantas informações que nos chegaram dos textos gregos, refere-se à citação da professora titular do curso de História e Arqueologia da Grécia Clássica e Helenística do Museu de Arqueologia e Etnologia da Universidade de São Paulo e que nos traz novos fatos históricos que se encaixam no texto de Sófocles, aumentando ainda mais nossas possibilidades dentro da pesquisa e que torna este capítulo um recorte fundamental para o entendimento do mito e da trágica existência e passagem do tirano da cidade de Tebas, principal cidade-estado da região da Beócia, até sua ligação definitiva com Atenas, principal cidade-estado da região da Ática.

Quando criança Édipo foi exposto e, de acordo com o texto, o pastor de Laio, conhecido por Menetes, não teve coragem de matá-lo, então o entregou ao pastor Forbas

\footnotetext{
${ }^{49}$ BORBA FLORENZANO, Maria Beatriz. Nascer, Viver e Morrer na Grécia Antiga. Atual Editora. S. P. 1996. Págs. 18-20.
} 
de Corinto conforme o texto trágico de Sófocles na fala do mensageiro, “[...] lembras-te de que me deste uma criança um dia para eu tratar como se fosse um filho meu? [...] ${ }^{\natural 50}$, e assim, Édipo é salvo e entregue para ser criado e educado por Pôlibo e nos permite dizer que foi em Corinto que essa criança que teria a morte como berço, recebeu o seu verdadeiro lar. Seu senhor e protetor lhe daria o nome de Édipo. O que justifica o significado do nome Édipo ou "oidípus, que do radical da palavra em grego quer dizer "Pé-Inchado" (ou "Pés-inchados"?)"51.

No entanto, existem duas versões bem diferentes na exposição de Édipo.

“[...] Na primeira, o futuro rei de Tebas é colocado num cofre e lançado ao mar, mas salva-se porque o (lárnaks (arca, urna funerária ou sarcófago)) chegou a Corinto ou Sicione [...]", e completa “[...] a exposição sobre um monte, no caso específico de Édipo, tornou-se a preferida, já que, através da mesma, se passou a ter um sinal específico (os pés inchados ou os calcanhares perfurados) para um reconhecimento futuro e um aítion (causa), um motivo, que the explicasse o nome. Na segunda versão, ele é simplesmente abandonado no monte Citerão. Seja numa ou seja a noutra versão, "o fato é que Édipo, na maioria das versões, foi criado e educado na corte de Corinto como filho de Pôlibo e Mérope" [...]",52.

${ }^{50}$ SÓFOCLES. Édipo Rei. Tradução do grego Mario da Gama Kury. Rio de Janeiro: Ed. Jorge Zahar. 2001, $5^{a}$ ed. Pág. 78, versos 1340-1342.

${ }^{51}$ BRANDÃO, Junito de Souza. Mitologia Grega. Rio de Janeiro: Ed. Vozes, 1993, $5^{\text {a }}$ ed. Vol. III. Pág. 243.

${ }^{52}$ BRANDÃO, Junito de Souza. Mitologia Grega. Rio de Janeiro: Ed. Vozes, 1993, $5^{\text {a }}$ ed. Vol. III. Pág. 244. 
Quando dissemos em nossa análise que Édipo foi um fugitivo de Corinto, estamos trilhando o caminho que o leva da cidade de Corinto até Tebas. E nosso herói somente pode trilhá-lo devido ao insulto de um anfitrião de Pôlibo, que durante uma festa, após ter ingerido muito vinho chamou-o de filho adotivo. Angustiado, no outro dia procura o oráculo de Delfos e descobre que tem sobre si uma maldição: ele matará seu pai e desposará sua mãe. Trecho que encontramos nos versos 1182 a 1187 da tragédia de Sófocles, quando Édipo justifica seu desaparecimento de Corinto ao mensageiro:

\section{Édipo \\ “[...] disse Apolo que eu teria \\ de unir-me à minha própria mãe e derramar com estas minhas mãos o sangue de meu pai. Eis a razão por que há numerosos anos vivo afastado de Corinto, embora saiba que é doce ao filho o reencontro com seus pais [...]"}

Então, após ouvir tamanha desgraça sobre seu destino, Édipo, desesperado sobre o que poderia fazer, foge de Corinto, para evitar que a maldição se cumpra. Sem rumo certo, mais uma vez ele é um homem sem pátria. Um indigente claudicante à mercê da vida. Exposto novamente, à solidão, ao abandono, à miséria, ao tempo e suas intempéries. A dor e o sofrimento agora são seus companheiros de caminhada. De príncipe a andarilho foi uma grande queda e consequentemente a angustia e o ódio serão também seus companheiros. Nada o deterá. E seja qual o caminho que ele seguir nada o impedirá do retorno. Jamais verá Pôlibo e Mérope, para ele seus verdadeiros pais. Então

${ }^{53}$ SÓFOCLES. Édipo Rei. Tradução do grego Mario da Gama Kury. Rio de Janeiro: Ed. Jorge Zahar. 2001,

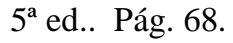


continua sua fuga, guiado pelas estrelas e pelo sol causticante, Édipo torna-se um fugitivo de suas dores.

Na estrada que segue, as Fúrias enovelam seu destino colocando em sua mão a realização da maldição a que estava predestinado. Na encruzilhada de Pótnias, marco de separação entre Delfos e Dáulis, Édipo se encontra com uma carruagem que vinha em sentido contrário. As temíveis divindades, filhas do sangue de Cronos, iniciam a purificação e purgação em Édipo da maldição provinda de seus ancestrais. A justiça será feita. A morte do dragão de Ares por Cadmo será vingada, o desprezo para com Dioniso impetrado por Lábdaco e o envolvimento amoroso e suicídio de Crisipo por Laio também serão. Sobre as costas do fugitivo essas divindades vingadoras do sangue planam a vingança com a maldição. A cólera, o delírio, a cegueira e o ódio abrem a retaguarda do espírito de nosso jovem para que tudo se cumpra.

Essa carruagem que vem em sentido contrário ao caminho de Édipo é o suficiente para que nosso herói perca o mínimo senso da razão. "O arauto e o próprio passageiro me empurraram com violência para fora do caminho" ${ }^{54}$, diz Édipo na tragédia de Sófocles, e foi o estopim para uma chacina imediata. A comitiva trazia o rei Laio amparado por cinco soldados que seguiam em sentido ao oráculo de Delfos para obter respostas e ajuda sobre a maldição da Esfinge que estava destruindo a juventude tebana. Quando forçam Édipo a se desviar do trajeto, ele, tomado de ódio, trava uma luta e mata a todos os integrantes da comitiva, inclusive o rei. Apenas uma pessoa consegue fugir

\footnotetext{
${ }^{54}$ SÓFOCLES. Édipo Rei. Tradução do grego Mario da Gama Kury. Rio de Janeiro: Ed. Jorge Zahar. 2001, $5^{\text {a }}$ ed.. Pág. 59, versos 962 e 963.
} 
sem que Édipo perceba justamente o pastor que deveria tê-lo assassinado quando bebê. Cometido o assassinato de Laio, estão vingadas as injustiças do passado e cumprida a maldição de Laio e seu filho, porém está imposta sobre Édipo sua harmatia, essa falha trágica que agora impregna seu espírito e toda a sua desventura. Com as mãos tingidas de sangue, Édipo segue seu percurso. A saga do nosso herói está apenas começando. Ele caminha. Coxo. Claudicante. Manco. Seu companheiro é seu bastão de apoio. Sua trajetória e seu caminho têm um porto de chegada: a cidade de Tebas.

Com as mãos manchadas de sangue esse andarilho do infortúnio chega à poderosa Tebas das sete portas. De imediato fica sabendo que, nas vizinhanças da cidade, "a Esfinge, um monstro fabuloso com cabeça e busto de mulher, corpo de leoa, cauda em forma de serpente, asas de ave, garras de leoa e voz humana",55, mantinha a cidade prisioneira punindo a todos que não adivinhassem seu enigma. Esse ser ctônio, sedento por prazer sexual, violador e devorador de jovens "fora enviada por Hera, a protetora dos amores legítimos, contra Tebas, para punir a cidade do crime de Laio, que raptara Crisipo, filho de Pélops, introduzindo na Hélade a pederastia. Postada no monte Fíquion, próximo da cidade, devastava o país, devorando a quantos lhe passassem ao alcance. Normalmente propunha um só enigma aos transeuntes, e já havia exterminado a muitos, porque ninguém ainda o decifrara",56. Foi então que surgiu Édipo e diante do enigma que dizia o seguinte:

\footnotetext{
${ }^{55}$ SÓFOCLES. Édipo Rei. Tradução do grego Mario da Gama Kury. Rio de Janeiro: Ed. Jorge Zahar. 2001,

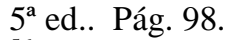

${ }^{56}$ BRANDÃO, Junito de Souza. Mitologia Grega. Rio de Janeiro: Ed. Vozes, 1993, $5^{\text {a }}$ ed., Vol. I. Pág, 245.
} 
"[...] Existe um bípede sobre a terra e um quadrúpede, com uma só voz, e de quantos viventes que vagueiam sobre a terra, no ar e no mar, é o único que contraria a natureza; quando, todavia, se apóia em maior número de pés, a rapidez se enfraquece em seus membros" [...] . A segunda versão, bem mais simples, é a seguinte: "Qual o animal que, possuindo voz, anda, pela manhã, em quatro pés, ao meio-dia, com dois e, à tarde, com três? Édipo responde que "é o homem, porque, quando pequeno, engatinha sobre os quatro membros; quando adulto, usa as duas pernas; e, na velhice, caminha apoiado a um bastão. [... $]^{957}$.

Vencida, a Esfinge, esse cruel monstro, alma penada, simbologia de Crisipo, se lança do alto de um rochedo e morre, permitindo a entrada triunfal de nosso herói.

Após a morte do ser misterioso e sobrenatural, as portas de Tebas se abrem para nosso perspicaz adivinho. “Os que conseguiam responder as questões propostas pela Esfinge, decifrar seus enigmas ou suportar seu peso esmagador, receberiam em troca, como vencedores, tesouros, talismãs, conhecimento de determinados segredos e até mesmo um reino e uma rainha"58, e de fato é o que acontece na tragédia de Sófocles, Édipo será o rei de Tebas e se casará com a rainha.

Então, apoiado em seu bastão, com as roupas definhadas pelo tempo, trazendo as armas de Laio como prêmio, com as mãos e o rosto enlameados de sangue e seus pés

\footnotetext{
${ }^{57}$ BRANDÃO, Junito de Souza. Mitologia Grega. Rio de Janeiro: Ed. Vozes, 1993, $5^{\text {a }}$ ed., Vol. III. Pág, 261.

${ }^{58}$ BRANDÃO, Junito de Souza. Mitologia Grega. Rio de Janeiro: Ed. Vozes, 1993, 5ª ed., Vol. I. Pág, 249.
} 
deformados, nosso jovem indigente sai do anonimato para ser recebido como um enviado dos deuses e o melhor dos homens na cidade de Tebas como seu novo rei e herói.

De pária para herói foi um salto gigantesco e imediato. A Grécia passa a ser novamente seu lar amado que o recebe com os braços abertos. Tudo parece estar maravilhoso, idílico, abençoado. Enfim as dores cessaram e o passado, por enquanto, será uma recordação guardada atrás das sete portas. A figura do herói ressurge poderosamente na tragédia de Sófocles e Édipo, o decifrador de enigmas, adentra as portas da cidade coroado com os louros da vitória para tornar-se rei absoluto de Tebas.

Como pode um feito simbólico como o de Édipo, transformar do nada, Édipo, um mero mortal, numa celebridade heróica tal qual os grandes guerreiros de Tróia? A saga do herói está tão presente no mito de Édipo como Orestes está para Ésquilo e Jasão para Eurípides. Mas, para se tornar um herói, nos moldes da mitologia e sociedade grega, o indivíduo tem que passar por alguns rituais iniciáticos, aprendizados, conquistas, reinados e desventuras. Se organizarmos passo a passo o mitologema edipiano numa ordem sistemática do nascimento, vivência e morte de Édipo, com certeza ele se enquadra nesse padrão.

Abrimos aqui um pequeno recorte sobre essa saga para construirmos nosso herói. De acordo com Joseph Campbell em seu livro O Herói de mil Faces, essa construção tem uma dinâmica muito simples, "um herói vindo do mundo cotidiano se aventura numa região de prodígios sobrenaturais; ali encontra fabulosas forças e obtém uma 


\section{vitória decisiva; o herói retorna de sua misteriosa aventura com o poder de trazer}

benefícios aos seus semelhantes"59, conceito totalmente aplicado à desenvoltura de nosso jovem herói, que desde seu nascimento e sobrevivência até sua saída de Corinto e chegada a Tebas numa trajetória recheada de momentos fabulosos, especiais e excepcionais, sendo inclusive, posteriormente, elevado a divindade protetora de Atenas na tragédia Édipo em Colono.

No entanto, ao que concerne a formação desse herói, independente do status que carregará, estão outros valores fundamentais adicionados ao homem-herói. Estes valores são encontrados na própria formação do homem grego. $\mathrm{O}$ universo do fabuloso, mágico e lendário caracteriza o mito. Porém, a estrutura comportamental desse homem em todos os âmbitos da sociedade e na sua relação com ela é que definirá realmente o homemherói agregado ao seu mito, para torná-lo um homem excepcional dentro de padrão específico adotado pelos gregos e conseguir sobreviver na estrutura fantástica de um ser mitológico.

Nas escrituras das epopéias helênicas de Homero, na Ilíada e Odisséia, encontramos esse padrão de homem e de herói. Ele fundamentalmente possui uma virtude que está associada em sua essência histórica à formação do modelo de homem grego dos tempos mais antigos ao que podemos denominar com o conceito de arete $^{60}$.

\footnotetext{
${ }^{59}$ CAMPBELL, Joseph. O Herói de mil Faces. Tradução de Adail Ubirajara Sobral. São Paulo: Editora Pensamento. 2007. Pág. 36.

${ }^{60}$ Os gregos entendiam por arete sobretudo uma força, uma capacidade. Às vezes definem-na diretamente. Vigor e saúde são a arete do corpo; sagacidade e penetração, a arete do espírito. Pode-se também por respeito, prestigio. Mas objetivamente a arete de alguém está na qualificação de "uma força que lhe é própria e que constitui a perfeição do homem grego". Esta é uma das definições que encontramos na Paidéia: a Formação do Homem Grego de Werner Jaeger, página 19.
} 
Termo que podemos aplicar e estender à figura de Édipo, onde a virtude de nosso jovem herói estabelece o mais alto nível heróico que o rei vai assumir até o final da peça, independentemente do que aconteça e dos conflitos que nele existem.

O que não se pode ignorar é que Édipo, mesmo sendo filho amaldiçoado, ele compõe esse quadro redesenhado por Sófocles como um homem extremamente virtuoso, moralmente correto e prudente que, "na vida privada como na guerra, rege-se por normas certas de conduta, alheias ao comum dos homens" ${ }^{\mathbf{6 1}}$, tanto que encontramos no início da tragédia de Sófocles a fala do sacerdote de Zeus enaltecendo Édipo como “o melhor dos homens ${ }^{\mathbf{9 2}}$, instigando-o a revelar o seu aspecto heróico e o confrontando com o elogio e a reprovação. Caso ele não resolva o problema da peste estará com sua honra em jogo.

A atitude de Édipo diante a multidão de pestilentos será, sem sombra de dúvida, a busca incondicional para a resolução do problema. E é nessa busca que o mito vai se caracterizando e se estruturando de forma magnífica, tendo como base esse superhomem-herói, transportado para uma época onde Péricles objetivava esse ideal que estava se perdendo. Então, a força do mito busca no passado o que os gregos do presente século V a.C. deviam aspirar, e Jaeger confirma:

\section{“[...] Os Gregos, porém, viram nisso a aspiração da pessoa ao ideal e suprapessoal, onde começa o valor. De}

\footnotetext{
${ }^{1}$ JAEGER, Werner Wilhelm. Paidéia: a Formação do Homem Grego. Tradução de Artur M. Parreira. São Paulo: Ed. Martins Fontes. 1986. Pág. 20.

${ }^{62}$ SÓFOCLES. Édipo Rei. Tradução do grego Mario da Gama Kury. Rio de Janeiro: Ed. Jorge Zahar. 2001, $5^{a}$ ed. Pág. 20, verso 43.
} 


\section{certo modo pode-se dizer que a arete heróica se aperfeiçoa com a morte física do herói. Ela reside no homem mortal, ou melhor, ela é o próprio homem mortal; mas perpetua-se, mesmo depois da morte, na sua fama, isto é, na imagem da sua arete, tal como o acompanhou e dirigiu na vida $[. .$.$] , 63$}

Nesse contexto, a tragédia de Sófocles coloca a personagem de Édipo exatamente como o ideal de homem que os gregos desejavam ser e se encontravam. Tanto que no desenrolar da peça não queremos que Édipo descubra toda a sua verdade. Teremos compaixão e sofreremos junto com o herói no final da peça. Nesse ponto reside a nobreza desse herói e o mito resiste ao tempo, propagando um ideal de homem que os atenienses precisavam ser - independente da maldição - pois é ela que faz Édipo ser o que é; um herói impregnado de auto-estima, vida e virtude. Que prefere o sofrimento, a dor, o exílio, a verdade, do que viver uma vida inteira de insignificâncias e conflitos íntimos da mais alta significância.

Então nosso herói adentra a cidade sob os aplausos e a admiração da multidão aliviada, coroado como rei. Retorna para sua cidade natal, origem de seu flagelo e suas desventuras quando criança. Ele, claudicante, reaviva nos umbrais do passado a maldição que pesa sobre seu espírito. O homem salvador traz consigo uma nova desgraça para a cidade. Não demorará muito para as Fúrias justiceiras lançarem sobre ele uma nova investida de horrores e sofrimentos e testar mais uma vez sua virtude, defrontando-o com o espelho de sua alma.

\footnotetext{
${ }^{63}$ JAEGER, Werner Wilhelm. Paidéia: a Formação do Homem Grego. Tradução de Artur M. Parreira. São Paulo: Ed. Martins Fontes. 1986. Pág. 23.
} 
O indigente de outrora sobe lentamente, apoiado em seu bastão, as escadarias do palácio em direção ao trono que fora de seu pai - um homem que jamais o desejou como filho. No cimo dos degraus, submissa ao edito do seu irmão Creonte, Jocasta aguarda silenciosa seu novo esposo e senhor. As Fúrias gargalham o desfecho da maldição como madrinhas da desgraça da união incestuosa do filho e da mãe no matrimonio maldito lançado por Hera.

O jovem herói que se apóia em seu bastão com seus pés deformados (herança da crueldade de Laio) torna-se o novo rei de Tebas. Suas marcas do passado que acompanham cada passo desse herói não incomodam Jocasta em nada? Tebas terá como líder absoluto um rei coxo, incapaz de lutar em uma guerra e defender sua cidade como realmente um herói helênico faria, tendo ninguém questionado essa deformidade presente em Édipo? Será Jocasta, representante da mulher grega, tão submissa ao ponto de não questionar a origem dessa aberração física e os traços semelhantes de Édipo com Laio? Será que o mito de Édipo fora esquecido pelos gregos do século V a.C., ou a encenação de Sófocles era tão bem realizada que esse detalhe passou desapercebido? Qual foi a verdadeira intenção de Sófocles em esconder esse defeito; apenas a liberdade poética? Não podemos afirmar nada, mas podemos questionar, e procurar minuciosamente nas entrelinhas da tragédia os textos que nos apontam para tais interrogações e encontrar as fontes que permitem nosso questionamento.

Não será agora o momento para discutirmos esses preciosos detalhes, pois devemos seguir a jornada de nosso jovem herói para iluminarmos ainda mais nossa empreitada e não seguirmos os mesmos caminhos que tantos outros estudiosos seguiram, 
para confrontarmos com maior clareza nossa análise. Isto não significa que eles estivessem errados, mas existe uma necessidade em nossa abordagem de observar o mito com um olhar não somente mais critico sobre Sófocles e sua tragédia e construirmos uma outra visão que para muitos passou despercebida ou não foi foco de suas pesquisas.

Então Édipo se uniu a Jocasta e com ela teve quatro filhos. O jovem agora é pai. Conseguiu a proeza de fazer quatro filhos em uma mulher muito mais velha que ele. Afinal já havia se passado vinte e um anos entre ele ser exposto no monte Citerão e ter retornado para Tebas. Ou seja, Jocasta já não era nenhuma mocinha, provavelmente ela já não era mais um símbolo de fertilidade para um jovem como ele e para o trono de Tebas, pois é fato que os gregos sempre se casavam com mulheres muito mais novas, com idade entre dezesseis e dezoito anos, porque assim elas lhes poderiam dar filhos muito mais sadios. Ou Jocasta era realmente muito jovem na época de seu casamento com Laio, ou não era a primeira esposa de Laio e talvez uma segunda esposa, pois a primeira, que foi a mãe verdadeira de Édipo foi esquecida no decorrer do mito ou eliminada na criação de Sófocles.

Muitos anos se passaram e tudo caminhava bem. Os filhos homens, Etéocles e Polinices, já estavam crescidos e as filhas mulheres, Antígona e Ismene, ainda eram duas meninas que brincavam pelo palácio da família. Mas algo muito terrível estava para acontecer. Uma peste, lançada pelo deus Ares, inicia uma hecatombe sem dimensões por toda a cidade. Corpos amontoados se espalham apodrecendo ao ar livre, lançando seus odores fétidos pelo ar, espalhando seu flagelo na morte dos rebanhos, crianças e mulheres. A terra torna-se infértil, improdutiva e estéril. Gemidos, soluços e gritos de 
dor se misturam à turba de suplicantes que arrastam seus ramos de loureiros, oliveira e incensos por toda a parte e todos os templos. O caos transborda no seio da cidade transtornada e tudo que até então era paz torna-se dor, sofrimento e desassossego.

É assim que Sófocles inicia sua tragédia. É desta versão e visão assombrosa no início da peça que vamos enxergar Édipo no frontispício do palácio real para atender caridosamente o povo que lhe pede por socorro. São estas linhas maravilhosamente bem escritas, meticulosamente trabalhadas e dotadas de inúmeras informações, que possibilitaram a nós e tantos outros estudiosos vasculhar a origem do mito de Édipo. Não que esta seja a única tragédia que nos traz informações sobre o rei tebano, mas esta é a única que nos chegou por completo trazendo as informações necessárias com os dados comparativos para nossa pesquisa sobre as relações entre Édipo e Jocasta.

Até este momento tudo o que dissemos sobre o mito de Édipo estava contido na história do seu passado, seu nascimento, criação e chegada até Tebas. A partir do instante em que trouxemos as informações sobre a peste que assolava a cidade, damos continuidade ao mitologema. Embasados na tragédia que Sófocles no século V a.C., utilizamo-a como documento principal. A partir dela seguimos o caminho pelo qual Sófocles escreveu o seu Édipo Rei que inicia sua ação já como rei de Tebas enfrentando uma peste que assola toda a cidade.

É justamente a partir desta tragédia, que os relatos presente na escrita do autor nos leva juntamente com Édipo, a seu passado. Esta busca de Édipo para entender os acontecimentos presentes leva-o a realizar um flash back da sua vida e das personagens 
que o acompanham. Este entendimento do passado o fará entender o presente e consequentemente leva o rei de Tebas a identificar as falhas trágicas, se descobrir parricida e reconhecer-se incestuoso.

Esta trama, reelaborada por Sófocles, faz de sua tragédia uma obra prima do teatro grego, considerada por Aristóteles a mais bem elaborada até hoje e motivo de diversos estudos existentes por inúmeros pesquisadores até hoje.

Apesar da excelência enaltecida por inúmeros estudiosos sobre esta versão da tragédia é justamente nela que encontramos diversas falhas contextuais, as quais nos tem intrigado muito. Fazendo um paralelo entre a verdadeira origem de Édipo e sua relação com Jocasta, o autor da obra usa da sua liberdade poética para adequá-la ao comportamento político, social e cultural que predominava na época da escrita e encenação da tragédia no século V a.C. em Atenas, permitindo a nosso estudo essa contextualização entre o que possa ser originário do mito e o que possa ter sido adulterado pelo tempo ou ignorado por Sófocles.

Para completarmos o mitologema edipiano, continuamos seguindo o caminho do nosso herói, porém utilizando, a partir dessa parte da dissertação, o texto da tragédia que foi escrito por Sófocles e encenado no ano de 430 a.C. ${ }^{64}$ aproximadamente, na cidade de Atenas. Na época, quando Péricles tinha sessenta anos e dominava o cargo de estratega, numa cidade que estava à beira do seu colapso total com a guerra do Peloponeso, que

\footnotetext{
${ }^{64}$ SÓFOCLES. Édipo Rei. Tradução do grego Mario da Gama Kury. Rio de Janeiro: Ed. Jorge Zahar. 2001,
} $5^{\mathrm{a}} \mathrm{ed}$. 
exigia a fidelidade absoluta dos atenienses, procurando incentivar conceitos e comportamentos do homem desse tempo, buscando no passado heróico a força motriz para reavivar sua Arete perdida no tempo, entre tantas transformações que toda a Grécia já havia passado, principalmente a cidade de Atenas.

Édipo, bode expiatório ou não, vítima fatídica de suas próprias atitudes, encontrase na frente de seu palácio, paramentado de rei, para acalmar a população desesperada com a peste que destruía a cidade. O povo espera dele, novamente, a salvação dos cidadãos tebanos. Já que foi ele quem libertou a cidade da Esfinge, somente ele poderá livrar a cidade desse novo mal.

O rei se manifesta invocando sua antiga geração e sua posição do salvador de Tebas, dizendo que já tomou as devidas providências enviando Creonte, seu cunhado e irmão de Jocasta, até o oráculo de Delfos para trazer informações sobre o que fazer a partir das informações fornecidas pelo deus e segui-las radicalmente, como vemos nos versos 96 a 98 da tragédia de Sófocles. Édipo diz que “eu não serei então um homem de verdade se não fizer tudo que o deus ditar por intermédio de Creonte" ${ }^{\text {"65 }}$, se antecipando, sem medir consequiências, que tomará qualquer atitude, seja ela qual for, para salvar a cidade.

Exatamente no momento em que Édipo, o sacerdote de Zeus e toda a população tebana se encontravam diante do palácio, Creonte chega de Delfos com as informações

\footnotetext{
${ }^{65}$ SÓFOCLES. Édipo Rei. Tradução do grego Mario da Gama Kury. Rio de Janeiro: Ed. Jorge Zahar. 2001, $5^{\text {a }}$ ed. Pág. 21, versos 96 aos 98.
} 
que o rei mandou buscar. Édipo, que tem urgência em resolver a situação, exige que Creonte fale, diante de todo a povo, a mensagem que o oráculo proferiu: "teremos de banir daqui um ser impuro ou expiar morte com morte, pois há sangue causando enormes males à nossa cidade" ${ }^{66}$, completando que o assassino que matou Laio, vive na cidade de Tebas, portanto será necessária a purificação desse mal, execrando tal individuo da cidade, como única forma de erradicação dos males causados pela peste.

Então, após saber que a mácula do assassino prolifera todo tipo de dor e sofrimento em Tebas, Édipo anuncia para o povo tebano seu edito e decisão:

Édipo

"[...[ Já que somente os fatos alegados honram-me os tebanos com a cidadania declaro neste instante em alta voz, cadmeus: ordeno a quem souber aqui quem matou Laio, filho de Lábdaco, que me revele tudo; ainda que receie represálias, fale!

Quem se denunciar não deverá ter medo; não correrá outro perigo além do exílio; a vida lhe será poupada. Se alguém sabe que o matador não é tebano, é de outras terras, conte-me logo, pois a minha gratidão virá juntar-se generosa recompensa. [...] [...] O criminoso ignoto, seja ele um só ou acumpliciado, peço agora aos deuses

\footnotetext{
${ }^{66}$ SÓFOCLES. Édipo Rei. Tradução do grego Mario da Gama Kury. Rio de Janeiro: Ed. Jorge Zahar. 2001,
} $5^{\text {a }}$ ed. Pág. 23, versos 124 aos 126. 


\section{que viva na desgraça e miseravelmente! \\ E se ele convive comigo sem que eu saiba, invoco para mim também os mesmos males que minhas maldições acabam de atrair inapelavelmente para o celerado! [...]}

\section{[...] E quanto aos desobedientes, peço aos deuses que a terra não lhes dê frutos e as mulheres não tenham filhos deles, e sem salvação pereçam sob o peso dos males presentes ou vitimas de mal muitas vezes maior. [...]"67}

Ou seja, o nosso herói lança sobre ele, sem o saber, sua própria expulsão, trazendo sobre si todas as maldições provenientes dos últimos acontecimentos ocorridos na cidade, tornando-se uma vítima expiatória em nome da cidade. Édipo não sabe, mas ele pagará o tributo no lugar de todos e essa atitude, mesmo que pareça impensada, é uma ação digna de um grande herói e de um homem livre para agir e se responsabilizar por suas atitudes.

Imaginar, pois é o que nos resta, a personagem dizendo esse texto em pleno teatro grego, deve ter sido algo magistral, pois os atenienses conheciam o mito, sabiam o que iria acontecer com Édipo, o quanto ele sofreria no decorrer da encenação. Não há dúvida de que a platéia foi tocada no seu mais íntimo sentimento. A partir de então, vão sofrer com Édipo, penalizar-se-ão com suas dores e todos serão invadidos por um terror abissal, uma piedade sem limites que realizará em seu íntimo a purgação e a purificação de suas almas.

\footnotetext{
${ }^{67}$ SÓFOCLES. Édipo Rei. Tradução do grego Mario da Gama Kury. Rio de Janeiro: Ed. Jorge Zahar. 2001,
} $5^{a}$ ed. Pág. 28 e 29, versos 261 aos 272, 289 aos 295 e 320 aos 324. 
Édipo não medirá esforços para saber quem foi o assassino de Laio e antecipando-se a todos manda chamar Tirésias, um adivinho respeitadíssimo na cidade e em toda a Grécia devido aos seus dons divinatórios. Pede pela salvação da cidade, para afastar a maldição que ainda emana do rei morto. Mas Tirésias, que já sabe que Édipo é o assassino, evita proferir as suas palavras de adivinho e ambos iniciam uma discussão que os levará a cólera, à insensatez e à verdade, mas Édipo continuará reincidente em suas perguntas, forçando o adivinho a dizer o que sabe. Depois de inúmeros insultos e provocações por parte de Édipo, Tirésias diz que Édipo é o assassino que ele procura. No entanto, cego em seu ódio o rei não acredita e duvida que essa seja a verdade, acusando Tirésias de conspiração junto com Creonte para derrubá-lo do trono.

Na tentativa de livrar a cidade da peste, Édipo inicia um processo que o levará à derrocada. Seus sentidos e sua razão vão atropelando suas atitudes, cegando-o em suas ações. Hábil, inteligente, dono do poder absoluto em Tebas, ele se antecipa a todos. Seu pensamento está sempre a frente de qualquer atitude alheia. O que demonstra sua virtude, mesmo que essas atitudes levem-no para a má fortuna. Assim nosso herói cumprirá sua pena, não imposta, mas fruto do seu livre arbítrio, liberdade de pensamento e ações. Não são os deuses que o condenam, mas as suas próprias escolhas e sua frase “quem age sem receios, não teme as palavras"68, ou seja, ele, o rei, e sua palavra é a verdade, o resto não interessa.

\footnotetext{
${ }^{68}$ SÓFOCLES. Édipo Rei. Tradução do grego Mario da Gama Kury. Rio de Janeiro: Ed. Jorge Zahar. 2001, $5^{\text {a }}$ ed. Pág. 29, verso 351.
} 
No entanto, essa atitude vai mudar conforme o andamento da tragédia, pois Édipo ainda não sabe de nada e tudo está nebuloso. Um véu muito tênue esconde toda a verdade, mas ele optou por não dar ouvido às palavras de Tirésias e assim, para cada dúvida, uma nova verdade vai surgindo, e a cada descoberta uma nova acusação. Mas o herói se assenta sobre suas verdades e com isso vai penetrando num jogo perigoso, onde o cheque-mate cairá sobre ele.

Cego em seus propósitos, ele acusa Creonte e Tirésias de conspiração dizendo que "Creonte em tempos idos, amigo fiel, agora se insinua insidiosamente por trás de mim e anseia por aniquilar-me, levado por um feiticeiro, charlatão, conspirador que só tem olhos para o ouro e é cego em sua própria arte" ${ }^{99}$, desrespeitando uma das maiores autoridades religiosas da época e acusando seu próprio cunhado.

A confirmação que Tirésias lhe fez surgiu como um insulto e não como uma revelação, o que torna Édipo ainda mais relutante, inflexível e até então inabalável. Porém a resposta de Creonte e a chegada de Jocasta desencadearão novas situações, transformando a verdade, que até então era a única que o rei conhecia.

Assim que Creonte fica sabendo que Édipo culpa-o de traição, ele retorna ao palácio para tirar satisfações com o rei e novamente voltam as discussões, acusações e cóleras de ambos os lados. Mas Édipo novamente se adianta em todos os seus argumentos e fatos acusando Creonte e Tirésias incansavelmente. Somente ele, o rei, é

\footnotetext{
${ }^{69}$ SÓFOCLES. Édipo Rei. Tradução do grego Mario da Gama Kury. Rio de Janeiro: Ed. Jorge Zahar. 2001, $5^{a}$ ed. Pág. 29, versos 462 aos 467.
} 
possuidor da verdade e ninguém mais. No comportamento do homem ateniense, ele está saindo do métron, que é a sua medida, a medida de cada um, e caindo na desmedida, na ultrapassagem do que lhe é possível, o que o levará consequentemente à moira, atraindo para si a justiça divina, a punição.

A discussão entre Creonte e Édipo chega até Jocasta, que sai do palácio para interferir no debate e acalmar os ânimos de ambos. Mas a rainha quer saber do marido "por que razão, senhor (dize-me pelos deuses), permites que essa cólera feroz te vença?"70, e Édipo sem relutância diz "ele me acusa, a mim, de ter matado Laio",71, usando como porta-voz um adivinho. Então, sem saber do ocorrido com Édipo no passado, Jocasta reabre a ferida, dizendo que um dos interpretes de Febo, "comunicou a Laio, por meio de oráculos, que um filho meu e dele o assassinaria; pois apesar desses oráculos notórios todos afirmam que assaltantes de outras terras mataram Laio há anos numa encruzilhada." ${ }^{, 72}$, e completa falando da maldição que fora lançada sobre a criança que mataria o próprio pai mas que a profecia não se cumpriu porque assassinaram a criança no terceiro dia de vida, lançando-a num precipício.

Ao terminar de ouvir o relato sobre como Laio morreu, Édipo entra em desespero, e o homem de postura inabalável se enche de temores e aflições ao ouvir sua esposa falar que Laio foi morto em uma encruzilhada na região de Fócis, no entroncamento das estradas que vão para Delfos e Dáulia e assim o rei, dominado pelo desespero inicia uma

\footnotetext{
${ }^{70}$ SÓFOCLES. Édipo Rei. Tradução do grego Mario da Gama Kury. Rio de Janeiro: Ed. Jorge Zahar. 2001, $5^{\mathrm{a}}$ ed. Pág. 53, versos 837 aos 838.

${ }^{71}$ SÓFOCLES. Édipo Rei. Tradução do grego Mario da Gama Kury. Rio de Janeiro: Ed. Jorge Zahar. 2001,

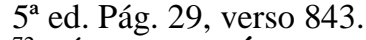

${ }^{72}$ SÓFOCLES. Édipo Rei. Tradução do grego Mario da Gama Kury. Rio de Janeiro: Ed. Jorge Zahar. 2001, $5^{a}$ ed. Pág. 54, versos 853 aos 857.
} 
tempestade de perguntas para Jocasta sobre quando se deu o fato, como era a aparência de Laio, como era a escolta que protegia o antigo rei e como ela ficou sabendo de todos esses detalhes. Assim, a rainha segue seu diálogo confirmando cada pergunta com a resposta exata. Mas para Édipo suas respostas não foram o suficiente, ele quer a presença da única prova viva para comprovar os fatos, Menetes, o fiel pastor de Laio, que fugiu apavorado do massacre ocorrido na encruzilhada.

\section{“Ele virá, mas creio merecer também uma palavra tua sobre teus receios" $"$,} completa Jocasta, receosa por ver o marido tão desesperado e inquieta com tantas perguntas. Assim, Édipo conta toda a sua história desde o dia da festa em Corinto, quando um bêbado o acusou de filho adotivo; sua ida até o oráculo de Delfos que anunciou que ele se uniria com sua própria mãe após assassinar o pai; da sua fuga de Corinto sem rumo certo para um lugar bem distante; do seu encontro com uma carruagem, exatamente no local que Jocasta disse e da morte de todos os integrantes que estavam no carro.

Mediante tais relatos de Édipo, todos se aterrorizam. Jocasta confirma o que ouviu do pastor e da morte do filho ainda bebê, mas Édipo persiste em ouvir do escravo de Laio a afirmação de que foram vários homens que assassinaram Laio. No entanto, o que ninguém sabe é que o pastor, segundo Junito de Souza Brandão:

\footnotetext{
${ }^{73}$ SÓFOCLES. Édipo Rei. Tradução do grego Mario da Gama Kury. Rio de Janeiro: Ed. Jorge Zahar. 2001, $5^{\text {a }}$ ed. Pág. 29, versos 916 aos 917.
} 


\begin{abstract}
"[...] salvou-se da fuga. Jocasta recebeu por ele a notícia da morte do esposo, mas recebeu-a totalmente incorreta e mentirosa: o rei e três de seus acompanhantes haviam sido mortos por salteadores. $O$ escravo fugiu, permitindo que um forasteiro matasse a todos os outros da comitiva, mentiu por vergonha, adulterando o acidente; e, para ocultar sua covardia, afirmou que a carruagem fora atacada por bandoleiros. [... $]^{974}$
\end{abstract}

O desespero e a preocupação tomam conta de todos. Afinal, qual será realmente a verdade? Seria necessário revirar o passado para concluir os fatos, questiona Jocasta diante do santuário. Mas ela teme a persistência de Édipo na sua ânsia desenfreada por querer saber a verdade.

Então, como um deus ex machina ${ }^{75}$, surge a figura do mensageiro de Corinto a procura de Édipo para informar-lhe que seu pai Pôlibo está morto e que "os habitantes de Corinto querem fazer de Édipo seu rei"76. Tal informação vem como um socorro e enche de alegria Jocasta. Enfim, o pai de Édipo não é Laio e sim Pôlibo, o que caracteriza, para Jocasta, o fim do temor e do parricídio.

\footnotetext{
${ }^{74}$ BRANDÃO, Junito de Souza. Mitologia Grega. Rio de Janeiro: Ed. Vozes, 1993, $5^{\text {a }}$ ed., Vol. III. Pág. 245.

${ }^{75}$ Segundo o Dicionário de Teatro de Patrice Pavis, página 92, O deus ex machina (literalmente o deus que desce numa máquina) é uma noção dramatúrgica que motiva o fim da peça pelo aparecimento de uma personagem inesperada. Em certas encenações de tragédias gregas (especialmente em Eurípides), recorria-se a uma máquina suspensa por uma grua, a qual trazia para o palco um deus capaz de resolver, "num passe de mágica", todos os problemas não resolvidos. Por extensão e figurativamente, o deus ex machina representa a intervenção inesperada e providencial de uma personagem ou de alguma força qualquer capaz de desenrolar uma situação inexplicável [...]. O deus ex machina é usado, muitas vezes, quando o dramaturgo encontra dificuldade para achar uma conclusão lógica e quando procura um meio eficaz para resolver de uma só vez todos os conflitos e contradições [...]. No caso do aparecimento de Forbas, foi o argumento e forma que Sófocles encontrou para resolver a trama final em Édipo Rei (nota do autor).

${ }^{76}$ SÓFOCLES. Édipo Rei. Tradução do grego Mario da Gama Kury. Rio de Janeiro: Ed. Jorge Zahar. 2001, $5^{\text {a }}$ ed. Pág. 64, versos 1116 aos 1117.
} 
Mas o mensageiro não é apenas uma personagem colocada na peça para trazer o alivio e sim a confirmação do fato. Este mensageiro que acaba de chegar de Corinto é Forbas, o pastor que recebeu das mãos do pastor de Laio a criança que ficaria exposta e morreria por inanição ou devorada por animais da floresta, e a doou aos reis de Corinto. Ou seja, ele é ao mesmo tempo o alívio e o desespero. Para Sófocles é a personagem da salvação do seu texto trágico. Ele é a peripécia e o reconhecimento de Édipo diante de sua desventura. Forbas pode até ser considerado a personificação das Fúrias que tramam sua vingança e vêm através do pastor trazer o fatídico desfecho.

No entanto, o que para Jocasta torna-se alivio, para Édipo ainda é preocupação, pois Mérope está viva, o que não evita que ele venha a unir-se com sua mãe. Porém, o mensageiro afirma que Édipo não é filho legitimo de Pôlibo e Mérope, confirmando que ele era realmente um filho adotivo, encontrado no Citérão com os tornozelos traspassados e o salvou cuidando de seus ferimentos e depois o levou, ainda criança, para os reis de Corinto.

$\mathrm{Na}$ precipitação e desencadeamento dos fatos, Édipo não mede esforços para saber quem é o pastor de Laio que ainda vive e sabe de toda a verdade, e manda buscálo. Jocasta desespera-se, tenta evitar, mas é inútil sua interferência, Édipo está cego na busca de sua verdadeira origem. Para ele nada mais importa, somente a verdade deve prevalecer, custe o que custar. Na condição de rei, herói e salvador de Tebas, Édipo é um homem de virtudes cavalheirescas e no seu caráter não cabe a mentira e muito menos a omissão dos fatos. 
Assim que o pastor de Laio chega Édipo inicia seu interrogatório com Menetes. A cada pergunta o esclarecimento e a concretização de um fato. Então, a espessa nuvem de escuridão que cobria suas amargas recordações vai-se tornando cada vez mais tênue e a clareza das informações fornecidas pelo pastor, que é obrigado a revelá-las, vai desnudando a figura de Édipo até o seu reconhecimento completo como parricida e incestuoso.

O desfecho e o efeito trágico propriamente dito são apoteóticos. Édipo, transtornado, segue em direção ao palácio. O coro, desolado, compartilha e desabafa sua dor para a platéia, relembrando os feitos do herói tebano. Do palácio ouvem-se os gritos enlouquecidos de Jocasta e Édipo, seus lamentos, suas desventuras e logo em seguida um silêncio sepulcral. O criado retorna do palácio e relata minuciosamente os fatos ocorridos, para o total delírio da platéia. E assim se aplica sobre Édipo a frase: conheçate a ti mesmo. Concretizando sua real função como rei, salvador e purificador da maldição que até então assolava toda a cidade.

Como Édipo ordena, no início da tragédia de Sófocles $^{77}$, o banimento absoluto do assassino de Laio da cidade e terras de Tebas, ele cumprirá a sua palavra, mas antes de partir permanecerá até sua recuperação. Na época em que o deus decidir, ele irá, acompanhado e amparado por sua filha Antígona, para o bosque das Eumênides, no

\footnotetext{
${ }^{77}$ Ver os versos 253 aos 327 da tragédia Édipo Rei de Sófocles com tradução do grego Mario da Gama Kury editado pela Jorge Zahar em 2001, na sua $5^{\text {a }}$ edição, nas páginas 28, 29 e 30.
} 
povoado de Colono, nas proximidades de Atenas, local designado pelo deus Febo, onde encontrará abrigo, paradeiro e a morte digna de um herói ${ }^{78}$.

Assim se concretiza o mito de Édipo na versão que utilizamos da tragédia de Sófocles. No entanto, o mito tem suas inúmeras variantes e por ser tão vasto, não podemos reduzir o mitologema a está única versão sofocliana, por sinal vestido a rigor pela arte incomparável de Sófocles. Mas cabe-nos informar, que na primeira versão que temos do mito:

\section{"[...] O futuro rei de Tebas é colocado num cofre e lançado ao mar, mas se salva porque o cofre chega em Corinto ou Sicione. No entanto, a versão da exposição sobre um monte, no caso específico de Édipo, tornou-se a preferida, já que, através da mesma, se passou a ter um sinal específico (os pés inchados ou os calcanhares perfurados) para um reconhecimento futuro.[... $]^{\text {"79 }}$}

o que permitiu Sófocles trabalhar com precisão cirúrgica sobre o mito.

Como ele se salva também temos uma outra variante que contraria qualquer bom senso, como afirma Marie Delcourt:

\footnotetext{
${ }^{78}$ SÓFOCLES. Édipo em Colono. Tradução do grego Mario da Gama Kury. Rio de Janeiro: Ed. Jorge Zahar. $2001,5^{\text {a }}$ edição.

${ }^{79}$ BRANDÃ̃, Junito de Souza. Mitologia Grega. Rio de Janeiro: Ed. Vozes, 1993, $5^{\text {a }}$ ed., Vol. III. Pág. 242.
} 
"[...] Os pés inchados se constituem num absurdo, qualquer que seja o ângulo de análise. Um recém-nascido abandonado no mar ou num monte está sujeito à morte, com os pés amarrados ou livres. Vários gramáticos antigos pressentiram o problema e tentaram solucionálo: um escólio ao v. 26 das Fenícias explica que os pais de Édipo o mutilaram, a fim de que o menino não fosse recolhido e educado. [... $]^{, 80}$

ocasionando sua morte, já que, naquela época, uma criança que estivesse exposta, sendo perfeita e robusta, seria salva.

Enfim, várias são as fontes que nos levam esclarecer o mitologema edipiano, para concluirmos que toda a sua saga, independentemente das suas diversas variantes, foi realmente cristalizada na poesia trágica de Sófocles, completa Junito de Souza Brandão:

"[...] Mas a redução do mito a uma obra literária tem outra conseqüência no que respeita à documentação mitológica: o mito vive em variantes, e nelas se contém; e a obra de arte de conteúdo mitológico forçosamente reflete apenas uma dessas variantes. Dado o imenso prestígio alcançado pela poesia na Hélade, a versão do poeta, ao narrar o mito, impunha-se à consciência pública: instituía-se dessarte o mito canônico, com abandono das demais variantes, talvez de menor eficácia do ponto de vista artístico, mas nem por isso de menor

${ }^{80}$ BRANDÃO, Junito de Souza. Mitologia Grega. Rio de Janeiro: Ed. Vozes, 1993, $5^{\text {a }}$ ed., Vol. III. Pág. 243. 
importância do ponto de vista religioso. $E$ foi isto exatamente o que aconteceu com o mito de Édipo. Dada a beleza da tragédia Édipo Rei e a autoridade olímpica de Sófocles, o mito por ele poetizado passou a ser a cartilha por onde se reza e se psicanalisa. [... $]^{\prime 81}$

e por onde, no universo teatral contemporâneo, também se teatraliza a mesma cartilha que Sófocles escreveu.

${ }^{81}$ BRANDÃO, Junito de Souza. Mitologia Grega. Rio de Janeiro: Ed. Vozes, 1993, $5^{\text {a }}$ ed., Vol. III. Pág. 238. 
JOCASTA: MÃE, MADRASTA OU INVENÇÃO DE SÓFOCLES?

Creonte, meu irmão, em nome da cidade ofereceu-me num decreto irrevogável a quem pudesse decifrar corretamente o enigma da virgem sutil, comprometendo-se a dar-me como esposa a nosso salvador. 
Da mesma forma que revisitamos o mito de Édipo e nele encontramos suas variantes, a mesma postura faz-se necessária e obrigatória na investigação do universo feminino de Jocasta, e do comportamento desta na tragédia de Sófocles. O que nos permite retirar inúmeras conclusões a cerca da mulher que esteve ao lado de Édipo.

Pouco se fala desta rainha que teve um papel importantíssimo na tragédia de Sófocles, na vida de Édipo e na vida e pensamento da mulher, como representante de uma casta social feminina no século V a.C. na Atenas comandada por Péricles, onde a tragédia se fez presente no teatro de Dioniso e dela se fez a cartilha que todos seguem até hoje.

É notório que as personagens femininas nas tragédias ocupam um espaço importante enquanto responsáveis pela trama trágica do texto. No entanto, todas sofrem o suplício arrebatador da inação, com a investidura masculina sobre suas atitudes, posicionando-as num aquém do poder matriarcal sobre o patriarcal, o que torna clara a submissão da mulher em todas as referências que temos e a negação de sua palavra sob a palavra do homem grego, mais especificamente sobre o homem grego de Atenas. Esse age impondo-lhes a insígnia do silêncio e a não viverem plenamente em suas casas, numa dependência total e absoluta ao homem em todas as instâncias de sua existência.

Não estamos aqui fazendo apologia ao universo feminino do período, mas, mediante os fatos históricos que denunciam tais comportamentos, torna-se obrigatória a nossa postura, mesmo que (im)parcial, sobre o comportamento social da mulher ateniense. A sua atitude, postura, comportamento, influência e silêncio dentro do círculo 
em que viveu refletem-se diretamente na personagem histórica criada por Sófocles na tragédia Édipo Rei.

Segundo uma citação de Olga Rinne em seu livro Medéia: o Direito à Ira e ao Ciúme, as condições legais que regiam o comportamento da mulher estavam baseadas nos seguintes princípios:

"[...] Gyne, palavra grega para mulher, significa, de início, "parturiente". Para as sociedades da Grécia "clássica", o valor da mulher residia, antes de tudo, no fato de que, sendo a mãe dos filhos do homem, dava continuidade a sua estirpe. Na vida social, a mulher representava um papel subordinado; ela participava da vida social do homem e de seus amigos, permanecendo nas dependências destinadas às mulheres. Não gozava de direitos de plena cidadania (sempre vinculada à capacidade de portar armas) e não tinha, politicamente, a menor influência. Com o triunfo dos deuses masculinos, como sacerdotisa, foi banida do culto e seu lugar foi ocupado por um sacerdote; do mesmo modo que foi excluída do culto, foi excluída da cultura. Durante toda a vida, devia ter um tutor (primeiro, o pai, e, quando este falecia, o parente masculino mais próximo); não podia fazer negócios, aparecer em processos e não tinha bens nem herdava. Seu dote passava a ser propriedade do marido.

Sem autorização do pai ou tutor, ela não podia contrair núpcias; por outro lado, não tinha nenhuma possibilidade de recusar o marido que o pai lhe 


\section{destinava. [...][...] Como, devido ao trabalho pesado e aos muitos filhos, as mulheres envelhecessem e morressem mais depressa do que os homens, achava-se que a mulher devia ser mais jovem que o homem. [...]" 82}

Ou seja, as condições sociais que revestiam a atitude da mulher na sociedade grega eram de absoluta submissão ao direito patriarcal, colocando a mulher numa condição de total desigualdade perante o homem, posicionando-a em condições subumanas mediante a sociedade ateniense e a casta masculina que passou a reinar após a queda do matriarcado e a investidura brutal do patriarcado sobre o comportamento feminino na Grécia.

Assim, despossuída de direitos políticos ou jurídicos, a mulher ateniense vivia, a maior parte do tempo, enclausurada em seu lar, detendo no máximo o papel de organizadora das funções domésticas, estando de fato submissa a um regime de quase reclusão.

Separadas até mesmo dos membros masculinos da própria família, o gineceu era o seu único refúgio e alívio, junto a suas escravas. O silêncio da mulher sempre era bem

${ }^{82}$ RINNE, Olga. Medéia: o Direito à Ira e ao Ciúme. Tradução de Margit Martincic e Daniel Camarinha da Silva. São Paulo: Editora Cultrix. 1988. Pág. 73 e 74. 
vindo, e podemos observar que, até em Sófocles, "as mulheres deviam, por sua graça natural, permanecer em silêncio" ${ }^{\mathbf{8 3}}$, o que é por demais significativo de sua condição numa comunidade democrática, ou seja, calar a mulher significava, o mesmo que excluí-la inteiramente da cidadania. Vale dizer aqui o ditado muito usado nos termos do direito civil “quem cala consente" e, assim, a mulher ateniense não podia em hipótese alguma reverberar sua palavra no seio familiar e muito menos no da sociedade ateniense.

Mesmo na tragédia, onde Jocasta tem o papel fundamental no processo de reconhecimento de Édipo e sua maldição, torna-se evidente sua condição de rainha submissa diante de qualquer atitude que Édipo venha a tomar. Sua palavra é sempre descartada, ignorada e nunca proferida para o povo, sempre para o marido.

Mesmo sabendo do acontecido para interagir com profundidade no assunto, imediatamente a silenciam. Ao perguntar para o Corifeu sobre o que diziam Édipo e Creonte no debate recebe a seguinte resposta: "Basta. Creio que basta ficarmos onde a rude querela cessou. Nossa terra já está muito aflita"\$84, ou seja, mesmo sendo rainha, ela não podia saber o que ocorreu em um debate público. Posteriormente ela vai saber do próprio Édipo, mas isto já se passa no âmbito conjugal e não no da Ágora.

\footnotetext{
${ }^{83}$ ARISTÓTELES. Política. São Paulo: Editora Nova Cultural, 2004.

${ }^{84}$ SÓFOCLES. Édipo Rei. Tradução do grego Mario da Gama Kury. Rio de Janeiro: Ed. Jorge Zahar. 2001, $5^{\text {a }}$ ed. Págs. 53, versos 820 aos 822.
} 
O que equivale dizer que determinados assuntos, quando de importância geral, podiam ser expostos à esposa. No caso, não que ela era merecedora de conhecer tais assuntos, mas porque Jocasta sabe como ocorreu a morte de Laio e, portanto, será questionada quanto a este fato. Mesmo que ela seja a portadora da afirmação, será necessária a presença de um homem para confirmar seu relato e conhecimento do assunto. Enfim, ela nunca consegue completar e comprovar sua sabedoria perante o universo dos homens. Jocasta, no papel de esposa, terá sempre a intervenção de um ser masculino, o que coloca em dúvida a certeza de sua sabedoria, tendo sempre a sua frente um relator que interceda por ela e permita que suas palavras possam ser ouvidas através dele.

A relação da mulher no campo social da gênese grega nem sempre foi relegada às condições que as encontramos no século V a.C., em plena democracia ateniense. Seu status já foi muito mais elevado e a ela já foram consagrados templos e diversos espaços na sociedade grega, valorizando suas ações e atitudes, tanto que na própria formação do universo o feminino foi de suma importância, conforme explica Junito de Souza Bradão:

\footnotetext{
"[...] Géia, em grego Gaia, cuja etimologia ainda se desconhece, é a Terra concebida como elemento primordial a deusa cósmica, diferenciando-se assim, teoricamente, de Deméter, a terra cultivada. Géia se opõe, simbolicamente, como princípio passivo ao principio ativo; como aspecto feminino ao masculino da manifestação; Géia simboliza a função materna: é a Tellus Mater, a Mãe-Terra, a matriz que concebe todos
} 
os seres, as fontes, os minerais e os vegetais, sendo assim, a origem e matriz da vida, Géia recebeu o nome de Magna Mater, a Grande Mãe. [...]"85

O que se permitia era a mulher ser abençoada pelos deuses como procriadora e não apenas parideira, confinada ao círculo residencial para conceber e criar filhos saudáveis e guerreiros. Na sociedade grega antiga, o menino ficava aos cuidados da mulher até os sete (7) anos, quando então era retirado do convívio feminino para sua iniciação no mundo dos homens.

A causa brutal dessa deformação dentro da sociedade ateniense será o advento dos deuses masculinos sobrepondo-se aos femininos. Quando Zeus passa a ocupar o trono das divindades gregas, automaticamente a sacerdotisa é destituída do templo para ceder lugar ao sacerdote de Zeus, que passará a cuidar dos rituais sagrados no lugar da mulher.

Essa tomada do trono pelo homem será ao mesmo tempo a subordinação da mulher perante a sociedade, com uma ou outra diferenciação em outras pólis, mas nada que retorne a Géia o poder que lhe era próprio. Evidente que estas relações de poder estão num tempo distante na Grécia arcaica, mas sua reverberação nos séculos seguintes será fundamental para posicionar o homem diante da mulher e consequentemente deixarem

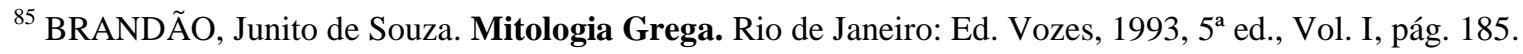


essa herança para toda a posteridade na sociedade ocidental, que se formará sobre esses princípios.

Não podemos negar que a mulher sempre foi um objeto de comercialização masculina, mas a forma de tratamento foi muito diferenciada entre um período e outro, como diz Florenzano:

"[...] No período homérico, por exemplo, a mulher fazia parte do circuito dos "bens preciosos" que circulavam entre os nobres, de forma que o dote era oferecido pela família do noivo. Embora a expressão "casamento por compra" tenha sido muito utilizada por estudiosos, ela, na verdade, é incorreta, pois o oferecimento dos presentes como dote na troca por uma noiva inseria-se num contexto de prestações recíprocas entre famílias, fortalecendo os laços de favores e contrafavores. Não era, portanto, uma "compra" simples. Essa situação transformou-se completamente depois, quando da formação da pólis grega e da emergência da democracia" $" 86$

É com base nestas informações a respeito da mulher que adentramos o universo feminino de Jocasta e sua relação com Édipo na tragédia escrita por Sófocles, pois é notória sua função procriadora no que concerne ao mito e à personagem. Porém, torna-se

\footnotetext{
${ }^{86}$ BORBA FLORENZANO, Maria Beatriz. Nascer, Viver e Morrer na Grécia Antiga. São Paulo: Atual Editora, 1996. Pág. 46.
} 
justa a analise realizada sobre a mulher e seu espaço na sociedade grega para entendermos com mais clareza às condições que foram impostas para a rainha e viúva de Laio dentro da escrita trágica do autor de Édipo Rei, que mediante os estudos históricos e os fatos colhidos permitem nossos argumentos e colocações diante da obra e seu autor.

Desta forma torna-se notório que para entendermos Jocasta e questionarmos suas atitudes na tragédia sofocliana no século $\mathrm{V}$ a.C. temos que mergulhar na preciosa fonte colhida em Junito de Souza Brandão, na qual se tornou a matéria prima sobre toda a pesquisa realizada, verticalizando nosso foco de trabalho em um dos seus estudos no seu livro Mitologia Grega volume III quando cita:

\begin{abstract}
"[...] $\mathrm{O}$ nome Jocasta, filha de Meneceu, aparece a partir de Sófocles, Édipo Rei, 950sqq. Segundo as variantes, os pulmões do mito, Jocasta não foi a primeira esposa de Laio. O rei de Tebas se teria casado em primeiras núpcias com Euricléia, filha de Ecfas, e dela tivera Édipo. Epicasta foi a segunda esposa. Donde, a seguir tal versão, "viva e atuante" no mito, Édipo, após a morte de Laio, desposou a madrasta Epicasta e não sua própria mãe, que aliás já havia falecido"
\end{abstract}

Torna-se obrigatório em nossa dissertação a busca de uma compreensão muito mais profunda sobre esta reviravolta existente no mito.

\footnotetext{
${ }^{87}$ BRANDÃO, Junito de Souza. Mitologia Grega. Rio de Janeiro: Ed. Vozes, 1993, $5^{\text {a }}$ ed., Vol. III. Pág. 238.
} 
A partir desse comentário de Junito de Souza Brandão, surge, dentro da tragédia de Sófocles, uma Jocasta carregada de dúvidas e mistérios e consequentemente o questionamento sobre sua autenticidade materna e, naturalmente, nos remete ao universo vivido pela mulher na sociedade ateniense do período conhecido por Era das Guerras (510-449 a.C.) até o período Clássico, onde Péricles é figura proeminente, (449-338 a.C.) e o total esfacelamento de Atenas com a guerra do Peloponeso.

É justamente nesse período de grandiosidade político-econômico-militar na cidade de Atenas, durante o magistratura de Péricles, através da Liga Délio-ática, que Sófocles escreve e encena sua cartilha de bom comportamento do espírito ateniense, revestido nas personagens do rei Édipo, Jocasta, Creonte, Tirésias, Sacerdote, Corifeu e o Coro de Tebas. Disfarçado sob uma máscara teatral, o autor expôs as relações humanas existentes em Atenas e não na antiga cidade da Beócia onde o mito tebano teve sua origem arcaica. Mas é, através da genialidade de Sófocles, que a versão do mito se perpetua na arte estabelecida. Adotada uma única variante, ignorando outras versões, a tragédia sofocliana reescrita agrega novos elementos trágicos incorporados pelo autor, tornando-a visceralmente mais trágica.

Não estamos aqui para condenar ou absolver Sófocles, mas para auxiliar na decodificação de sua tragédia e inserir mais uma interpretação sobre o riquíssimo conteúdo existente em sua obra. Tanto assim que, é sobre ela que pautamos nossa pesquisa para sairmos da ignorância e descobrirmos que sua versão nos serve de base e 
não de teto. Quando questionamos se Jocasta é mãe, madrasta ou sua invenção, não queremos denegrir a imagem do autor, ao contrário, estamos possibilitando mais uma reflexão sobre sua obra e a riqueza de conteúdos nela existentes e lhe atribuindo uma grande criação.

De acordo com citação de Junito entendemos que Laio fora casado por duas vezes e que Édipo era filho de Euricléia, ou seja, do primeiro casamento, portanto, ele não era filho de Jocasta. Sendo assim, seguindo os passos de Édipo torna-se notório, que ao chegar a Tebas, estaria no mínimo ferido, mal vestido, andando cocho apoiado em seu bastão, já que para andar ele necessitava de tal instrumento, pois claudicava.

Como se isso não bastasse, estava carregando consigo as armas da vítima abatida, ou seja, as de Laio, e Jocasta não percebeu nada disso? Se ela soubesse realmente do oráculo, da maldição imposta sobre Laio e seu filho, de imediato ela saberia quem era o rapaz de vinte e um anos que ali acabara de chegar, ou no mínimo, suspeitar de algo. Mas que motivo levou-a aceitar o casamento com o estrangeiro sem questionar absolutamente nada?

Ou seja, mesmo que Jocasta desconfiasse ou soubesse de algo, ela teria que ficar em silêncio diante o patriarcado reinante da época. A suposta mãe de Édipo não teve outra opção, a não ser se calar e casar. Mas poderia uma mulher ficar em silencio diante de tal situação? 
Será que foi por isso que Jocasta tentou durante toda a peça evitar conhecer a verdadeira origem de Édipo ou pelo fato de ser a segunda esposa de Laio, não sabia de nenhuma maldição? Isso ainda não sabemos, mas seu suicídio pode estar atrelado a essa atitude ou foi justamente através dessa personagem que, mediante o povo grego que detinha o maior poder no areópago, Sófocles pode fazer suas alterações sem ser questionado pela platéia grega.

Ainda resta a pergunta: Euricléia, Jocasta ou nenhuma delas? O que importa nesse momento é entendermos que algo muito superior ao mito pode estar por trás da escrita, da tragédia e de sua encenação, colocando não somente Édipo como vítima expiatória de toda essa trama, mas também, a figura feminina de Jocasta.

Sendo assim, a personagem feminina de Jocasta passa a ter uma importância fundamental na tragédia e em nosso estudo, visto que, analisando o comportamento da rainha através de leitura atenciosa e detalhada do texto observamos inúmeras fissuras que permitem a nosso olhar adentrar todo um universo mitológico correspondente a um passado distante que ficou no esquecimento, porém oculto nas entrelinhas da escrita, permitindo uma farta colheita com dados e informações valorosas ignoradas por Sófocles. 
Então, Jocasta ressurge em nosso trabalho não como madrasta e muito menos como mãe, mas como verdadeira e única esposa de Édipo. O que nos leva a dizer tal infâmia para alguns não é a insensatez de nosso pensamento, mas o argumento mais evidente encontrado no texto de Sófocles, tanto que, sobre a união incestuosa de Édipo e Jocasta, de imediato, nos pautamos nas evidências de que, assim que Édipo chega a Tebas é sabido que a rainha está com a cabeça a prêmio para se casar com o homem que decifrar o enigma da esfinge. Sendo Édipo o grande adivinho e salvador da cidade, sua união com Jocasta torna-se obrigatória.

Desse primeiro encontro entre os dois a identificação de Édipo seria imediata para a rainha, pois ele acabara de chegar, estava sujo, ferido, sangrando e com sangue nas mãos, carregando o troféu de sua última conquista: as armas do rei Laio. Como Jocasta não percebeu nada disso, acaso ela era cega? "No resumo de Pisandro de época tardia, Jocasta reconhece primeiro o assassino pelas armas de Laio, e em seguida seu filho Édipo" ${ }^{\text {,8 }}$ o que realmente é fato, pois sabemos que as armas do vencido eram levadas junto com o vencedor. Mas outra provável hipótese é que a partir da inserção de Jocasta no texto de Sófocles ao mito de Édipo se agrega a nova versão, dando origem ao texto trágico que chegou até os dias de hoje, sendo Euricléia esquecida no passado, tamanho o poder trágico e a beleza existente na obra Sofocliana.

\footnotetext{
${ }^{88}$ BRANDÃO, Junito de Souza. Mitologia Grega. Rio de Janeiro: Ed. Vozes, 1993, $5^{\text {a }}$ ed., Vol. III. Pág.
} 244. 
Outro dado é fundamental no reconhecimento do filho, como afirma Junito de Souza Brandão analisando os estudos de Marie Delcourt:

"[...] O sinal dos pés inchados ou perfurados de Édipo constituem um absurdo na matéria de reconhecimento. Não é possível que Jocasta, após tantos anos de casamento, não tivesse visto os pés deformados do filho e marido! Somente a literatura tardia os viu e valorizou? Mas, como acentua Marie Delcourt, quando um grande artista ou dramaturgo como Sófocles repete um episódio simultaneamente absurdo e supérfluo como este, é que o fato lhe deve ter sido imposto por uma mitopéia anterior. $[\ldots]^{9989}$

Seja como for é sabido que Édipo era um homem com problemas físicos sérios, visíveis, notórios que se evidenciam em seu andar cocho ou ainda que seja um outro problema no andar, mas sem dúvida nenhuma utilizava um bastão para se apoiar, como o próprio Édipo relata para Jocasta sobre o seu encontro com a comitiva de Laio quando diz que "valendo-me de meu bordão com esta minha mão feri-o gravemente" ${ }^{90}$, o que comprova, mediante a tragédia de Sófocles, que ele utilizava um bastão para se apoiar.

\footnotetext{
${ }^{89}$ BRANDÃO, Junito de Souza. Mitologia Grega. Rio de Janeiro: Ed. Vozes, 1993, 5ª ed., Vol. III. Pág. 244.

${ }^{90}$ SÓFOCLES. Édipo Rei. Tradução do grego Mario da Gama Kury. Rio de Janeiro: Ed. Jorge Zahar. 2001, $5^{a}$ ed. Pág. 59, versos 970 ao 971.
} 
Sendo assim, novas dúvidas surgem sobre a omissão ou obrigação de Jocasta diante do homem que está prestes a se tornar seu marido. Se ela era realmente a primeira esposa de Laio, de imediato o acusaria de assassino, pois a identificação das armas também seria notória. Se um dado tão importante como esse é omitido no texto, com certeza havia uma necessidade muito maior que a do próprio mito para não escancarar a verdade logo de imediato, assim como toda a peça perderia a graça, pois ali Jocasta testemunharia para toda a platéia, quem era o homem que havia chegado. Então a personagem se calou. Mas isso, pode não ser somente por uma opção de licença poética por parte de Sófocles e sim para afirmar a condição da mulher diante do estado.

Fustel de Coulanges em seu livro A Cidade Antiga diz que:

“[...] o casamento era, portanto, obrigatório. Não tinha finalidade o prazer; seu objetivo principal não estava na união de dois seres que se simpatizavam um com o outro e querendo associar-se para a felicidade e para os sofrimentos da vida. $O$ efeito do casamento, em face da religião e das leis, consistia da união de dois seres no mesmo culto doméstico, fazendo deles nascer um terceiro apto a perpetuar esse culto [... $]^{\prime, 91}$

\footnotetext{
${ }^{91}$ COULANGES, Fustel de. A Cidade Antiga: estudos sobre o culto, o direito, as instituições da Grécia e
} de Roma. São Paulo: Ed. Hemus: 1975. Pág. 42. 
Fato que encontramos na tragédia de Sófocles, onde Édipo da continuidade a sua prole tendo quatro filhos com Jocasta, sendo dois filhos homens (Etéocles e Polinícis) e duas filhas mulheres (Antígona e Ismene).

Mediante tal afirmação histórica torna-se evidente que Jocasta fora obrigada a casar-se com Édipo, mesmo que ele fosse o assassino de Laio. Ela não iria contra as leis impostas para a mulher daquela época. Além do mais, sua cabeça estava a prêmio, seu irmão Creonte ofereceu-a como troféu para aquele que decifrasse o enigma da Esfinge e Édipo o decifrou. A rainha não tinha outra opção a não ser casar-se com aquele estranho para dar continuidade à família e procriar um novo herdeiro para o trono de Tebas.

E se observarmos a questão do reconhecimento apenas pelos pés deformados, sua atitude não seria diferente diante do horror que se estampava ao ver aquele jovem vindo em sua direção, claudicando, apoiado no seu bastão para tomá-la como esposa. Provavelmente ela teria alguma reação que recordasse o passado. É sabido que Édipo foi exposto no monte Citerão aos três dias de vida pelas próprias mãos de Jocasta como confirma o pastor de Laio quando indagado por Édipo dizendo "sim, meu senhor; foi Jocasta, com suas próprias mãos"92 depois foi entregue pelo pastor Forbas para o rei e a rainha de Corinto, Pôlibo e Mérope, que o criaram.

\footnotetext{
${ }^{92}$ SÓFOCLES. Édipo Rei. Tradução do grego Mario da Gama Kury. Rio de Janeiro: Ed. Jorge Zahar. 2001,

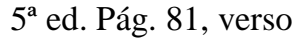


De acordo com os ritos da época, nem deu tempo da criança ser introduzida no seio familiar, muito menos ter sido aceita como integrante de uma família tebana, ou seja, segundo as leis instituídas na época, Édipo nunca pertenceu à família dos Labdácidas e muito menos à sociedade tebana.

Segundo Maria Beatriz B. Florenzano:

\begin{abstract}
"[...] o que valia na verdade era o momento em que a criança era apresentada a fratria (grupo de pessoas que acreditavam ter o mesmo ancestral) da família [...] duravam três dias, e era no terceiro dia que as criancinhas nascidas no ano que acabava de passar eram apresentadas a fratria. $O$ nascimento ficava registrado para fins sociais e paternidade consagrada [...].".93
\end{abstract}

Além desse existem vários rituais de incorporação da criança na família e sociedade ao qual nenhum deles se aplica em Édipo. Como já dissemos anteriormente, ele foi exposto aos três dias de vida sendo, portanto, eliminado como membro da família dos Labdácidas.

\footnotetext{
93 BORBA FLORENZANO, Maria Beatriz. Nascer, Viver e Morrer na Grécia Antiga. São Paulo: Atual Editora, 1996. Pág. 16.
} 
Para uma criança ser introduzida na família e ser aceita por ela, teria que passar por todos esses rituais, Édipo não passou por nenhum deles, automaticamente, podemos supor que ele não foi um filho criado por Jocasta, o que permite dizer que ela era totalmente ignorante diante do marido que a toma como esposa.

Assim, também, cabe nos dizer que ela não foi sua mãe e muito menos madrasta. Se seguirmos por esses caminhos que nos levam diretamente a um entendimento mais aprofundado do texto de Sófocles, percebemos a transgressão das variantes do mito para uma única versão e consequentemente seu engessamento e deformação como a única verdade existente, tornando-se o compêndio universal utilizado até hoje.

Essa transgressão, ou transformação do mito original pelo autor da tragédia acompanha nosso questionamento nas suposições, ou afirmações que tomamos como verdades. Sendo ou não verídicas não podemos menosprezar esses dados históricos, pois são eles, também, a constituição de nossos argumentos em face da desmistificação do mitificado e eternizado texto.

Se a rainha soubesse de toda a verdade e tivesse sido cúmplice da exposição de Édipo no monte Citerão com as cordas traspassadas ou até mesmo da mutilação de seus pés para não ser recolhido por nenhuma outra pessoa, ela, ao ver o jovem chegando e posteriormente no seu convívio familiar como marido, obviamente traria a tona recordações de um passado negro e obscuro da sua vida. 
Por mais que a mulher fosse enclausurada em sua residência e não tivesse voz para argumentar suas sensações e receios, uma explosão de ressentimentos e dúvidas estaria presente na sua personagem o que despontaria uma angústia aterradora diante de todo o acontecido.

No que diz a tragédia de Sófocles, o pastor de Laio afirma que Édipo "seria filho dele (Laio), mas tua mulher que deve estar lá dentro sabe muito bem a origem da criança e pode esclarecer-nos" ${ }^{94}$. Segundo o texto do pastor, subentende-se que a rainha sabia do ocorrido no passado e foi perceber a deformação nos pés depois de passar décadas junto dele, para concluir no final da peça a deficiência do marido e estabelecer o reconhecimento existente na peça mostrando-se como mãe e esposa depois de tanto tempo. Liberdade poética do autor aceitável, mas não que não possa ser questionada. Afinal essa deformação em Édipo é obvia e ululante para qualquer indivíduo que busque se aprofundar no texto e sua origem como reconhecimento no desfecho da tragédia.

A mesma frase citada acima, permite nova indagação a respeito de Jocasta. Será que Édipo não era filho legítimo de Laio? Esta suposição torna-se muito mais especulativa, em razão de não termos fontes precisas, tanto no mito quanto nos estudos existentes em nossa bibliografia. Porém, sendo considerada a mulher um ser inferior ao

\footnotetext{
${ }^{94}$ SÓFOCLES. Édipo Rei. Tradução do grego de Mário da Gama Kury. Rio de Janeiro: Ed. Jorge Zahar. 2001, $5^{\text {a }}$ ed. Pág. 81, versos 1369 ao 1371.
} 
homem, qualquer que fosse sua atitude contra as leis impostas, poderia receber graves e duras penas.

Tendo em vista que Jocasta foi a segunda esposa de Laio, ele não era mais nenhum mocinho e na velhice já poderiam lhe faltar forças para deixar um herdeiro, então, a rainha pode ter tido um filho fora do casamento. Fatos deste tipo ocorriam na sociedade da época, porém não eram aceitos, pela comunidade os filhos de uniões fora do casamento, e a criança acabava sendo exposta. Podemos dizer também que, pelo fato de Laio não poder ter um filho homem que perpetuasse a continuidade da família, em função da maldição proferida pelo oráculo, Jocasta teve um filho fora do casamento, tentando driblar a situação imposta por Hera. Descoberta a trama expuseram a criança com os pés mutilados a fim de que o menino não pudesse ser recolhido e morresse, o que não era nenhuma afetação contra as legislações da época, desde que a criança não tivesse passado pelos rituais da família. Estas duas situações permitem que Jocasta possa ser mediante a tragédia de Sófocles a mãe de Édipo, mas Édipo não ser o filho de Laio, o que contraria a maldição imposta e foge a um dos dados principais da mitopéia original.

Outra situação retirada em mais uma especulação é a união de um jovem herói com uma mulher muito mais velha. Se Édipo foi realmente filho de Jocasta, quando ele retorna, ela já é uma mulher muito mais velha, com a idade já avançada. 
É sabido que os gregos se casavam com mulheres muito mais jovens para encontrarem nelas a fertilidade suficiente para lhes darem bons filhos, fortes, saudáveis, guerreiros e capazes de dar continuidade a existência da família. Ou seja, na tragédia de Sófocles temos uma rainha velha e um herói cocho e até hoje ninguém questionou nada sobre isso? Historicamente esse dado torna-se importantíssimo na união de Édipo com Jocasta, tanto que na peça Greve do Sexo ou Lisístrata, de Aristófanes, encontramos o seguinte diálogo entre Lisístrata e o Comissário:

\section{"Lisístrata}

[...] Depois, quando o natural seria experimentar os prazeres da vida e gozar a mocidade com nossos maridos, ficamos em casa sozinhas por causa da guerra. Não quero nem falar no que nós, as casadas, sofremos com isso, mas para as solteiras ainda é pior, pois elas envelhecem solitárias em seus quartos... [...]

\section{Comissário}

E os homens, por acaso, não envelhecem?

\section{Lisístrata}

Ora, comissário! Não é a mesma coisa! Um homem quando volta da guerra, por mais velho que seja, trata logo de casar com uma gatinha. $\mathbf{E}$ a mulher, que tem a vida ativa mais curta? Se não aproveitar essa fase, ninguém mais vai querer casar com ela. A solteirona passa o resto da vida esperando uma coisa que não vem...[.... $]^{995}$

\footnotetext{
${ }^{95}$ ARISTÓFANES. A greve do sexo (Lisístrata). Tradução do grego Mario da Gama Kury. Rio de Janeiro: Jorge Zahar Ed., 2006, $6^{\text {a }}$ ed. Pág. 46.
} 
Texto que vai de encontro com nossa especulação sobre a união de mulheres mais idosas, dado que, como diz Lisístrata, "têm a vida ativa mais curta", significa que essas mulheres solteironas se tornam inférteis, ou seja, incapazes de lhes darem filhos. E Jocasta, não era uma mulher bem mais velha que Édipo? Provavelmente era, se a posicionarmos como primeira esposa de Laio, o que encontramos no texto que nos chegou de Sófocles. Mas esse fato também é ignorado na peça de Sófocles, pois Édipo se casa com Jocasta e com ela tem quatro filhos, o que significa que ela não era uma mulher infértil, longe disso. Era bem mais jovem do que imaginamos quando lemos o texto, onde se subentende que a rainha era uma mulher capaz de procriar filhos para Édipo e lhe dar continuidade à estirpe.

O porquê de Sófocles ter escrito sua tragédia omitindo esse fato não podemos esclarecer, mas podemos instigar o estudioso e leitor a uma revisitação mais atenta do texto possibilitando novas interpretações sobre a posição de Jocasta na tragédia e sua condição de representante feminina do século presente.

Novamente visitamos as leis gregas para situarmos Jocasta como uma das figuras femininas existentes nas tragédias para representar a mulher na sociedade grega daquele tempo. E, sobre elas, o posicionamento da lei é implacável em qualquer ato de independência social. Fustel de Coulanges diz que: 
"[...] Enquanto moça, está sujeita a seu pai; morto o pai, a seus irmãos e aos seus agnados; casada a mulher está sob a tutela do marido; morto o marido, não volta para a sua própria família porque renunciou a esta para sempre, pelo casamento sagrado; a viúva continua submissa à tutela dos agnados de seu marido, isto é, à tutela de seus próprios filhos, se os tem, ou, na falta destes, a dos mais próximos parentes do marido. 0 marido tem sobre ela tanta autoridade que pode, antes de morrer, designar-lhe um tutor, e até mesmo escolher-lhe novo marido. [.... $]^{996}$

Assim, podemos entender que Sófocles, estrategista e conhecedor pleno das leis vigentes em sua cidade, seguiu-as à risca. Na sua revisão do mito, criou novas situações, mas não adulterou as leis, inseridas propositadamente na tragédia como fonte de informação ao povo ateniense.

Sendo assim, Jocasta não teria outra saída. Mesmo que Édipo fosse seu filho, assassino de seu marido, ou qualquer indivíduo que seja, ela, na condição feminina, teria de se casar com ele, em face das leis na época da representação da tragédia, já que a versão sofocliana de Édipo Rei é totalmente focada na história do rei transgressor, imprudente e precipitado, apesar de sua coragem e virtudes inquestionáveis. Ou seja, o

${ }^{96}$ COULANGES, Fustel de. A Cidade Antiga: estudos sobre o culto, o direito, as instituições da Grécia e de Roma. São Paulo: Ed. Hemus: 1975. Pág. 69. 
texto tornou-se totalmente cristalizado em uma única idéia, não permitindo vazão para inserir nenhuma outra situação que remetesse à versão original do mito.

Outra fonte importantíssima para a compreensão da tragédia encontra-se no texto de Sófocles entre os versos 847 e 887 quando Jocasta explica para o marido como foram assassinados seu filho, ainda com três dias de vida, e Laio, seu primeiro marido. Durante o diálogo surgem novas indagações por parte do rei que relembra a ocasião em que assassinou todos os integrantes de uma comitiva que seguia em sentido contrário ao dele, exatamente na encruzilhada na região de Fócis, na convergência das estradas de Delfos e Dáulia.

Édipo entra em desespero e questiona a rainha sobre mais detalhes, é então que ela percebe quem é o marido com o qual conviveu durante anos dentro do mesmo palácio, se deitou diversas vezes e teve filhos dele "era alto; seus cabelos começavam a pratear-se. Laio tinha traços teus ${ }^{\text {"97 }}$. Ou seja, depois de tanta convivência nunca percebeu que Édipo era parecido com Laio, seu esposo assassinado?

Ainda que Sófocles tenha passado para a posteridade como o divino olímpico das tragédias, é interessante notar que nem um estudioso, desde Aristóteles até a atualidade, não se questionou sobre tais evidências. Algumas incongruências importantes

\footnotetext{
${ }^{97}$ SÓFOCLES. Édipo Rei. Tradução do grego Mario da Gama Kury. Rio de Janeiro: Ed. Jorge Zahar. 2001, $5^{\text {a }}$ ed. Pág. 56, versos 886 aos 887.
} 
mereceriam melhor análise num texto tão discutido, inclusive para fins psicoanalíticos. Não se questionar qual foi o real sentido em ocultar tais falhas torna-se um absurdo para muitos, afinal inúmeros estudos se pautam na tragédia de Sófocles como documento original e fiel do século V a.C.

Enfim, todos os dados colhidos remetem à ignorância abissal de Jocasta diante da verdade crucial do passado e no presente do texto sofocliano, subentendo que ela jamais soube da existência desse filho (que na verdade não o concebeu) e suas atitudes do não questionamento das diversas marcas de reconhecimento existentes em Édipo desde o início da peça até o final.

O que podemos dizer é que é plausível a existência de uma primeira esposa de Laio, chamada Euricléia em Homero, que foi a verdadeira mãe de Édipo. Após a tragédia de Sófocles ela desaparece do mito e se perde no tempo, para valorizar a estética e a poesia do autor. No entanto, quando Sófocles reescreve o mito faz do seu Édipo uma obra prima do teatro, que ecoa, instiga e se perpetua por mais de vinte e cinco séculos após sua encenação e escrita. Euricléia não figura nas linhas trágicas de Sófocles justamente pela fraqueza cênica e trágica na qual o texto mergulharia, tornando-o fraco e nada impactante no cenário representativo das grandes tragédias da época. 
O que nos cabe assegurar é que fazendo Jocasta mãe e esposa de Édipo, o incesto e o parricídio se fazem presentes. A partir da tragédia de Sófocles, Jocasta assume uma força colossal na tragédia, para enriquecer a figura do rei como personagem e possibilitar o tenebroso encontro entre o homem e o seu eu. Sem fuga do destino que lhe fora imposto, descamba na precipitação, degradação, infortúnio e desterro na qual terá que se sujeitar para concluir, no fim de tudo, o mito na sua excelência na purificação da cidade através de seu corpo e espírito.

Se um criador de homens e de almas como Sófocles, conhecedor profundo da vida humana como era e gênio na escrita de suas tragédias não adulterasse o mito, eliminando Euricléia, para dar vazão à personagem de Jocasta, a catarse, tão comentada e difundida por Aristóteles, perderia sua função na trama trágica. Ou seja, sem Jocasta incestuosa o elemento trágico não teria o mesmo fim religioso, político e social. O terror e a piedade perderiam sua força magistral. Em suma, para transformar o mito em teatro e torná-lo força presente no teatro, Euricléia teve que desaparecer para dar lugar a uma nova mãe concebida na criação fabulosa do autor, que fez de Jocasta uma personagem fascinante e trágica e que permitiu ao rei Édipo resplandecer absoluto na tragédia de Sófocles e se eternizar como uma das mais belas tragédias da literatura mundial do teatro até os dias de hoje. 


\section{ÉDIPO E JOCASTA: A RELAÇÃO TRÁGICA}

Édipo ilustre, muito querido!

Tu és o filho que atravessou a mesma porta por onde antes teu pai entrara; nela te abrigas num matrimônio jamais pensado!" 
Estabelecer a relação trágica entre Édipo e Jocasta a partir do texto de Sófocles é, antes de tudo, deixar claro que esta relação terá duas vertentes para posicionarmos o elemento trágico entre as figuras do rei e da rainha de Tebas. Estas duas fontes primordiais, pesquisadas e analisadas em nosso texto, revela-nos que uma das uma das variantes do mito permite-nos acreditar que Édipo era filho de Euricléia, primeira esposa de Laio, o que estabelece a não existência do incesto por parte de ambos, mas não descarta o assassínio de Laio pelo filho.

A segunda situação, que é a mais conhecida e divulgada em todos os meios acadêmicos até hoje, se pauta no texto original de Sófocles, de onde inúmeros estudos foram focados nas informações existentes nesse texto, cujo conteúdo relata a relação incestuosa do casal, sendo Jocasta mãe e esposa de Édipo. Isso permite na tragédia de Sófocles a caracterização fundamental do horror, terror e piedade transpostos para a cena teatral, alcançando, assim, seu objetivo final como obra literária concernente à encenação teatral do século V a.C..

Mito e teatro se amalgamam num contexto literário estabelecido pelo autor, que durante os concursos trágicos financiados pelo Estado, atingiam seus fins religiosos, sociais e políticos numa sociedade que perambulava entre as novas idéias que a ela se apresentavam. Desta forma, a tragédia edipiana refletia o estado de espírito desse povo, dialogando diretamente com seus sentimentos mais íntimos e Sófocles, trágico observador 
e entendedor de seu tempo, elabora seu Édipo Rei com o espírito necessário para atingir diretamente o povo ateniense do seu período.

Esta relação trágica somente pode existir a partir da adulteração do mito, pois sendo Jocasta apenas uma esposa, sem parentesco nenhum com Édipo, a tragédia não existiria com tanta intensidade, no estilo único que pertence ao trágico e suas conseqüências aterradoras, desde a ultrapassagem do métron até a conseqüência inevitável da moira. O que nos vale dizer que a imitação destas realidades dolorosas de Édipo e Jocasta, encontradas no mito, é a matéria prima do texto de Sófocles em sua forma bruta, porém tratadas com esmeroso polimento com que o poeta lapidou o mito para nele encontrar uma estética terrível e operante na catástrofe trágica.

É evidente que se o autor de Édipo Rei não trouxesse a tona "um catálogo de cenas dolorosas que tem um desfecho, as mais das vezes, trágico, infeliz"98 e altamente brutal, a tragédia em si perderia o sentido mimético a que se destina na purificação das emoções de quem a assiste, presencia e a ela se identifica apegados a uma determinada realidade, que no seu âmbito social é uma realidade artificial, mas que na encenação do mito e sua força matriz original, estabelece esse deleite, prazer e entusiasmo diante do horror de aparências e espantoso fim transformador.

\footnotetext{
${ }^{98}$ BRANDÃO, Junito de Souza. Teatro Grego: Tragédia e Comédia. Rio de Janeiro: Ed. Vozes, 2001, $8^{\text {a }}$ ed. Pág. 13.
} 
Quando Aristóteles define a tragédia:

“[...] uma imitação de uma ação de caráter elevado,
completa e de certa extensão, em linguagem
ornamentada e com várias espécies de ornamentos
distribuídos pelas diversas partes (do drama), (imitação
que se efetua) não por narrativa, mas mediante atores, e
que, suscitando o "terror e a piedade", tem por efeito a
purificação de tais emoções [...]" ${ }^{\text {"99, }}$

ele estabelece não uma norma específica sobre a tragédia, mas o teor de sua qualidade em suas partes designadas do mito, caráter, elocução, pensamento, espetáculo e melopéia, deixando claro que de todos os elementos "o mais importante é a trama dos fatos, pois a tragédia não é a imitação de homens, mas de ações e de vida" ${ }^{100}$, onde a felicidade e a infelicidade residem na ação da personagem, ou seja, nas ações de Édipo e Jocasta.

Para que estas ações reverberassem na forma imitativa do homem e nele causassem a purificação de seus diversos sentimentos, Sófocles teve que eliminar Euricléia, que foi a primeira esposa de Laio e consequentemente a mãe de Édipo, para estabelecer a trama a partir de Jocasta, não como madrasta, mas, como a verdadeira mãe, pois é nela, sendo a mãe incestuosa, que reside o poder do trágico sobre um Édipo que

\footnotetext{
${ }^{99}$ ARISTÓTELES. Poética. Tradução de Eudoro de Souza. Porto Alegre: Editora Globo. 1966. Pág. 245, parágrafo 27.

${ }^{100}$ ARISTÓTELES. Poética. Tradução de Eudoro de Souza. Porto Alegre: Editora Globo. 1966. Pág. 247, parágrafo 32.
} 
despenca da boa para a má fortuna na concretização do seu reconhecimento e afirmação do filho incestuoso.

No entanto, pela maneira como escreve a tragédia e nela deixa lacunas que permitem vasculhar as versões do mito, surgem os questionamentos sobre o texto, sua veracidade histórica e como espetáculo de uma época na criação de personagens tão humanas como às daquele século específico. Tanto que Jocasta é uma criação do seu imaginário teatral e não da condição humana de uma mulher que tenha existido, pois, com sua representação como rainha, torna-se um exemplar a ser seguido pela sociedade da época.

Sendo esta a posição de Sófocles, a tragédia permite que a relação dos dois seja uma hecatombe maravilhosa da literatura trágica no que diz respeito a esse estilo e estética teatral grega. O texto que nos foi legado torna-se uma fonte riquíssima de especulações nas relações dramáticas e no confronto das duas personagens centrais da trama e da sociedade ateniense no seu todo.

Mesmo com a adulteração do mito original explicito no texto, a obra de arte não se perde e nem perde seu valor, ao contrário, permite-nos entender a tragédia com muito mais profundidade, tornando nossa caminhada muito mais transparente diante dos fatos e da obra artística do poeta. Posicionar Édipo e Jocasta como mãe e filho unidos em matrimônio, não é uma atitude impensada, relapsa e inconseqüente de Sófocles, mas um 
posicionamento singular no universo trágico das duas personagens e torna a obra do tragediógrafo um exemplo magnífico da operante catarse exemplificada por Aristóteles.

Por mais que desvendemos os mistérios do texto, não há como fugir da sábia formação poética que Sófocles engendra em seu Édipo Rei, pois tamanha é a força com que o escreve que somente analisando cada bloco e a sustentação que cada um permite ao outro é que podemos avançar até o encontro dramático de Édipo e Jocasta. Tanto que cada incidente é uma precipitação ao abismo trágico da passagem da boa para a má fortuna das duas personagens.

Essas passagens são acompanhadas o tempo todo por impulsos de violência e cólera que se instauram nas personagens em diversos momentos do texto. É uma sucessão de acontecimentos e atitudes constantes que as envolvem desde a revelação oracular sobre a morte de Laio até o reconhecimento de Édipo e sua verdadeira origem. Segundo René Girard:

“[...] Já é a cólera que então conduz Édipo para fora de Corinto. E é a cólera que, em uma encruzilhada, levou-o a golpear o velho desconhecido que bloqueava sua passagem. [...] Analisando as coisas um pouco mais de perto, percebe-se que a "cólera" está sempre presente no mito. Sem dúvida, foi já uma cólera surda que 
incitou o companheiro de Corinto a levantar dúvidas sobre o nascimento do herói. Foi a cólera, na encruzilhada, que levou Laio a levantar, em primeiro lugar, o chicote contra seu filho. E é a uma primeira cólera, necessariamente anterior a todas as de Édipo, embora não realmente originária, que se deve atribuir a decisão paterna de se desfazer deste mesmo filho. [... $]^{\text {101 }}$

Assim como é a cólera dos deuses que lançam a peste sobre Tebas porque o assassino de Laio vive, e está presente em Tebas, é a cólera de Édipo que, ao lançar a maldição, expulsão e o desterro do assassino do antigo rei, cairá sobre ele mesmo determinando o seu fim.

O temor, a imprudência, a surdez e cegueira de Édipo diante de todos e principalmente diante de Tirésias e Jocasta é fruto da precipitação e da cólera que não permite que ele enxergue a verdade. É tão evidente o seu destempero a partir da informação de Creonte, que a cada tentativa de se afastar do precipício, mais próximo dele fica. É assim que Sófocles vai construindo o elemento trágico em toda a peça a partir de Édipo, que implacável em sua decisão e postura contamina a todos que estão a sua volta.

\footnotetext{
${ }^{101}$ GIRARD, René. A violência e o sagrado. São Paulo: Ed. Paz e Terra. 1990, $2^{a}$ ed. Pág. 92.
} 
A partir do momento em que Édipo profere “o criminoso ignoto, seja ele um só ou acumpliciado, peço agora aos deuses que viva na desgraça e miseravelmente! E se ele convive comigo sem que eu saiba, invoco para mim também os mesmos males que minhas maldiçoes acabam de atrair inapelavelmente para o celerado!"102 Ele sentencia seu fim. O restante da peça é o flash back fabulosamente articulado por Sófocles para esclarecer os fatos a partir do mito e ir construindo a peça, desvendando o passado do herói.

Quando Édipo decifra o enigma da Esfinge, automaticamente ele se torna esposo e dono de Jocasta através de um decreto irrevogável criado por Creonte. Esse decreto é relembrado por Jocasta na tragédia As Fenícias de Eurípides da seguinte forma:

\author{
Jocasta \\ “[...] Naquela época a Esfinge castigava \\ com sua crueldade a cidade de Tebas \\ e Laio, meu marido, já não existia; \\ Creonte, meu irmão, em nome da cidade \\ ofereceu-me num decreto irrevogável \\ a quem pudesse decifrar corretamente \\ o enigma da virgem sutil, comprometendo-se
}

\footnotetext{
102 SÓFOCLES. Édipo Rei. Tradução do grego Mario da Gama Kury. Rio de Janeiro: Ed. Jorge Zahar. 2001, $5^{\text {a }}$ ed. Pág. 29 versos 289 aos 295.
} 
a dar-me como esposa a nosso salvador $[. . .]^{\prime 103}$

Assim, o inevitável aconteceu e Édipo une-se a Jocasta para conceber na tragédia de Sófocles o fim trágico das duas personagens.

Bernard Knox argumenta que:

"[...] Na peça de Sófocles, a vontade do herói é inteiramente livre e ele é totalmente responsável pela catástrofe. Sófocles ordenou com cuidado o material do mito de modo a excluir da ação da tragédia o fator externo na vida de Édipo. Tal ação é a concretização da profecia, mas a descoberta de que ela já se realizou. A catástrofe de Édipo é descobrir sua própria identidade; e ele é o primeiro e o último responsável por esta revelação. Os acontecimentos principais da peça, na realidade, nem fazem parte da profecia: Apolo não vaticinou a revelação da verdade, o suicídio de Jocasta ou a cegueira auto-infligida de Édipo. [...]"104

O que enfatiza ainda mais nossos estudos e permite nossa especulação ou até mesmo uma suposta afirmação sobre a existência de uma outra mãe para Édipo.

${ }^{103}$ EURÍPIDES. As Fenícias. Tradução do grego Mario da Gama Kury. Rio de Janeiro: Ed. Jorge Zahar.

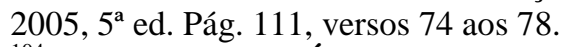

${ }^{104}$ KNOX, Bernard. Édipo em Tebas: o Herói Trágico de Sófocles e seu Tempo. Tradução de Margarida Goldsztyn. São Paulo: Ed. Perspectiva. 2002. Pág. 3 e 4. 
No que diz respeito ao filho que mataria o pai e se casaria com a mãe, já esta tudo consumado no início da peça e poderíamos dar por encerrado o espetáculo, o texto, o mito e tudo que nele existe. A genialidade de Sófocles é fabulosa no Édipo Rei, pois, em pleno século V a.C., ele concebe o primeiro drama policial da história do teatro. Tanto que para se chegar à origem do mito será necessária uma árdua investigação por parte do rei, que a cada instante desvenda uma situação, outras novas surgem a partir daquelas as quais desvendou. Assim, a cada passo dado por Édipo, na busca incessante pela verdade e clareza dos fatos, maior é sua aproximação do desfecho trágico do qual não conseguirá fugir.

O próximo passo será o encontro de Édipo com Tirésias e Bernard Knox, afirma que:

“[...] Esta profecia de Tirésias, entretanto não pode ser considerada um fator externo operando na peça, já que ele a profere somente como resultado da ação de Édipo em primeiro lugar. Tirésias havia decidido não dizer uma só palavra (343); o faz porque Édipo o ataca de forma tão violenta e inesperada que Tirésias se esquece de sua resolução de manter-se em silêncio. A profecia é extraída dele por Édipo, em suas próprias palavras: "forçaste-me a falar, contra a minha vontade"'(358). [...]"105

\footnotetext{
${ }^{105}$ KNOX, Bernard. Édipo em Tebas: o Herói Trágico de Sófocles e seu Tempo. Tradução de Margarida Goldsztyn. São Paulo: Ed. Perspectiva. 2002. Pág. 4.
} 
Em seguida, em função da persistência violenta e agressiva de Édipo ele profere a sentença "pois ouve bem: és o assassino que procuras!" 106, mas Édipo não cede aos desígnios da verdade e desaba em impropérios, contestações e dúvidas sobre o adivinho e o acusa de estar em conluio com Creonte para tomarem dele o trono.

Questionar, duvidar e acusar Tirésias é profanar uma autoridade máxima no âmbito religioso da época. Seria o mesmo que saquear um templo e declarar guerra às divindades. Mas essa atitude do rei leva Tirésias a despejar sobre ele uma nova maldição:

\section{Tirésias}

"[...] agora ouve: o homem que vens procurando

entre ameaças e discursos incessantes

sobre o crime contra o rei Laio, esse homem, Édipo,

está aqui em Tebas e se faz passar

por estrangeiro, mas todos verão bem cedo

que ele nasceu aqui e essa revelação

não há de lhe proporcionar prazer algum;

ele, que agora vê demais, ficará cego;

ele, que agora é rico, pedirá esmolas

e arrastará seus passos em terras de exílio, tateando o chão à sua frente com um bordão.

\footnotetext{
106 SÓFOCLES. Édipo Rei. Tradução do grego Mario da Gama Kury. Rio de Janeiro: Ed. Jorge Zahar.
} 2001, $5^{\text {a }}$ ed. Pág. 35 , verso 431. 


\section{Dentro de pouco tempo saberão que ele}

ao mesmo tempo é irmão e pai dos muitos filhos

com quem vive, filho e consorte da mulher

de quem nasceu; e que ele fecundou a esposa

do próprio pai depois de havê-lo assassinado!"’107.

A maldição de Tirésias é ao mesmo tempo reveladora quanto à conclusão do mito, mas é criadora das piores desgraças que Édipo terá que enfrentar em sua cruel existência. É a partir desse ponto da tragédia que a personagem de Jocasta se agrega a maldição oracular de Tirésias. Não que ele tenha lançado a maldição sobre ela, mas é a partir dos questionamentos incessantes de Édipo que ela também se descobrirá. Ou seja, Sófocles estabelece o poder das divindades num adivinho e num oráculo, para não fugir à religiosidade reinante na tragédia. Estas figuras na terra são os representantes divinos e deles não se deve duvidar ou descrer, como alerta Hesíodo aos reis quando diz: "escuta a justiça, Dike, não deixes aumentar a desmedida, Hybris." ${ }^{\text {"108 }}$. Atitude que foge completamente ao comportamento de Édipo.

A atitude de Édipo faz com que Creonte retorne para responder às afrontas proferidas pelo cunhado. Num debate acirrado, recheado de acusações lançadas por Édipo,

107 SÓFOCLES. Édipo Rei. Tradução do grego Mario da Gama Kury. Rio de Janeiro: Ed. Jorge Zahar.

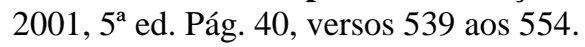

\footnotetext{
${ }^{108}$ VERNANT, Jean-Pierre. Mito e pensamento entre os gregos: estudos de psicologia histórica.
} Tradução de Haiganuch Sarian. Rio de Janeiro: Paz e Terra. 1990. Pág. 25. 
estabelece-se novamente um clima de tensão entre os dois. E mais uma vez Édipo é solicitado a ouvir quando Creonte o alerta:

\title{
Creonte
}

\section{“[...] Queres a prova? Sem demora vai a Delfos}

e informa-te se relatei fielmente o oráculo.

\author{
Ainda vou mais longe: se me convenceres \\ de haver-me conluiado como velho adivinho \\ merecerei dupla condenação à morte: \\ a minha e a tua. Não me acuses com base \\ em vagas, pálidas suspeitas sem me ouvir [...]"109
}

Mas a cólera e a cegueira que o dominam, não permitem que ele ouça qualquer tipo de conselho a não ser com a intervenção de Jocasta, somente a rainha cessará a discussão. No entanto, aquela que vem para acalmar traz a tempestade sem volta. Jocasta, o elo trágico de Édipo, é a confirmação da maldição imposta por Tirésias. Nela, Sófocles depositou o sêmen da desventura e do desterro do rei.

A partir da intervenção da rainha os fatos vão se tornando reais tanto para Édipo quanto para Jocasta, e, a cada tentativa de resolver a situação, maiores serão as mazelas

\footnotetext{
109 SÓFOCLES. Édipo Rei. Tradução do grego Mario da Gama Kury. Rio de Janeiro: Ed. Jorge Zahar. 2001, 5ª ed. Pág. 47, versos 705 aos 711.
} 
sobre eles aplicadas. A verdade de Sófocles repousava no silêncio da rainha, escondida e acobertada no seio do lar. Agora ela, a justiça implacável, está diante de todos e será implacável na sua conclusão. A cada diálogo uma revelação que estava encoberta aos olhos do povo surge de forma aterradora para ambos e deleite de quem contempla a cena teatral articulosamente elabora por Sófocles.

A chegada de Jocasta vem acompanhada de questionamentos sobre as atitudes de Édipo e a raiva que o domina serão as indagações e informações da esposa que precipitarão ainda mais as atitudes de Édipo. Na tentativa de dizer que Édipo não pode ser o assassino de Laio ela comenta:

\section{Jocasta}

“[...] Não direi que Febo, mas um de seus intérpretes há muito tempo comunicou a Laio, por meio de oráculos, que um filho meu e dele o assassinaria;

pois apesar desses oráculos notórios

todos afirmam que assaltantes de outras terras mataram Laio há anos numa encruzilhada [... $]^{\text {110 }}$

\footnotetext{
${ }^{110}$ SÓFOCLES. Édipo Rei. Tradução do grego Mario da Gama Kury. Rio de Janeiro: Ed. Jorge Zahar.

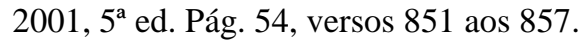


Tal revelação enche de temor e aflição o rei, que até então não tinha parado para ouvir ninguém. A partir desse momento Édipo não se posiciona mais na condição absoluta do sabedor de tudo, mas de quem teme ter passado da medida, no entanto já é tarde demais; as Fúrias já prepararam sua vingança e na tentativa de se livrar da flagelação maior será sua culpa.

Sobre o ponto de vista da tragédia, Jocasta torna-se a intermediaria dos deuses perante a justiça divina, pois é nela, a mulher que foi comercializada pelo irmão, que Sófocles deposita a última nódoa da maldição de Édipo. E é a partir dessa mácula aterradora que Jocasta passa a reinar como uma nova personagem no mito, elaborada pelo tragediógrafo em substituição a Euricléia, primeira esposa de Laio, para transformar Jocasta na mãe incestuosa com o filho.

Da mesma forma que o temor se apodera de Édipo ele também se apodera de Jocasta que, como num passe de mágica, começa a ver no esposo que esteve com ela durante anos traços de aparência física de Laio. Ela também exige respostas do marido e no questionamento do passado, que até então nunca foi especulado entre ambos. A partir desse ponto da peça, o flash back vai escancarando a vida do herói salvador de Tebas, trazendo a tona verdades escondidas por um homem possivelmente amargurado, doente e infeliz. 
A verdadeira personalidade de Édipo começa a aparecer. O herói complacente, piedoso, calmo e sereno do início do texto de Sófocles começa a desabar. A máscara que reveste seu semblante agora é trágica e suas atitudes remetem a um ser humano, mortal, falho como qualquer outra pessoa, mas que, mesmo diante de tudo, procura ser o homem idealizado, o senhor absoluto e o herói reformador do mundo. Tebas está desabando a sua frente, mas ele persiste na sua verdade única e absoluta.

Podemos dizer que Édipo é um homem que vive nos extremos da sua existência e, querendo ou não, ele traz na intimidade da sua personalidade uma intensa necessidade de superação, visto que sua deformidade o coloca inferior diante de todos. Qualquer desafio para ele é mais uma prova a ser superada, mas ele é o rei, e assim sendo, tem obrigação de resolver todas as situações, independentemente do que elas lhe vão lhe causar. Ele está agindo o tempo todo para provar sua capacidade, não só do homem decifrador do enigma da esfinge, mas do homem varão e do rei mantenedor e assegurador da coroa de Tebas.

Junito de Souza Brandão explica que um homem deformado como Édipo sempre cede passagem para todos devido à lentidão de seus movimentos. Em função dos seus pés mutilados, o vencedor da Esfinge não pode afastar-se depressa, andar rapidamente, tendo sempre que ceder devido à incapacidade de movimentar-se livremente pela estrada da vida. Agregado a isso, temos o filho adotivo, o príncipe que deixou o futuro trono de Corinto para viver como um errante que fugiu da maldição. 
Com o tempo, todas essas mazelas pessoais transformam-no num homem contido em função de seu passado, mas facilmente descontrolavel, "sua alma machucada, no entanto, apresenta-se vulnerável a toda e qualquer afronta e nada fere mais profundamente a psique doentia de um neurótico que ser tratada, não importa por quem, sem a devida consideração" "111, sendo assim, estas deficiências, fazem de Édipo um ser de aparências, onde provar sua capacidade torna-se a obrigação máxima em sua vida face à sua deformação.

Provar que não foi o assassino de Laio, ou constatar que o foi, torna-se o primeiro dilema investigativo de Édipo e de Jocasta. A rainha fornece as informações que lhe chegaram através da mentira inventada pelo pastor de Laio, procurando convencer o marido de que tudo não passa de uma coincidência, já que Jocasta sabe como foi a morte do ex-marido. Édipo quer ver a testemunha (o pastor) e ouvir dela a informação. As advertências de Jocasta não são o suficiente. O rei confia somente na sua própria sabedoria, nas informações que ele ouvir de outrem. A palavra de Creonte, Tirésias e Jocasta não foram o suficiente.

Édipo é o típico herói que precisa ver para crer. Ele duvida de tudo e de todos como se a sabedoria plena repousasse em sua consciência. A certeza, no seu caso, cega, reina junto com sua coroa. Todos mentem ou conspiram contra ele. O seu estado de vulnerabilidade neurótica desencadeia todas as situações que o levarão diretamente ao

\footnotetext{
${ }^{111}$ BRANDÃO, Junito de Souza. Mitologia Grega. Rio de Janeiro: Ed. Vozes, 1993, $5^{\text {a }}$ ed., Vol. III. Pág.
} 276. 
abismo. Para ele os deuses o amaldiçoam, os oráculos mentem e os adivinhos surrupiam seu poder. Tudo que é sagrado se perdeu nos novos valores e leis que ele instituiu na nova ordem política e social que ele mesmo criou.

É somente a partir do desespero e temor que se instaura sobre o rei que ele abre o seu universo pessoal para Jocasta, que até então não sabia com quem havia se casado. Assim Édipo se abre no divã do passado para remontar passo a passo toda a sua trajetória. Eis o momento crucial da tragédia, onde cada relato do rei remete à sucessão de conseqüências e revelações do herói e sua relação incestuosa e trágica com Jocasta. É a partir desse momento que Sófocles estabelece a sua versão do mito, a cartilha que os

menos curiosos irão seguir. A historinha contada por Édipo é a versão reconstruída pelo trágico. Poderíamos dizer que, nesse momento, a personagem de Édipo é a figura de Sófocles, fazendo o seu monólogo particular no teatro e na tragédia dizendo:

\section{Édipo}

"[...] Foi numa festa; um homem bebeu demais

e embriagou-se e logo, sem qualquer motivo, pôs-se a insultar-me e me lançou o vitupério de ser filho adotivo. Depois revoltei-me; a custo me contive até findar o dia. [...]

\section{[...] Sem o conhecimento dos meus pais, um dia} fui ao oráculo de Delfos mas Apolo 
não se dignou de desfazer as minhas dúvidas;

anunciou-me claramente, todavia

maiores infortúnios, trágicos, terríveis;

eu me uniria um dia a minha própria mãe

e mostraria aos homens descendência impura

depois de assassinar o pai que me deu vida.

Diante dessas predições deixei Corinto

guiando-me pelas estrelas, à procura

de pouso bem distante, onde me exilaria

e onde jamais se tornariam realidade

- assim pensava eu - aquelas sordidezas

prognosticadas pelo oráculo funesto [...]" ${ }^{112}$.

Mas porque Édipo foge e não retorna para Corinto? Seria muito mais sábio e prudente por parte dele retornar e falar da maldição com seus pais, que, diante de tudo, provavelmente lhe revelariam a verdade. Como o oráculo não desfez a sua dúvida, Édipo se precipita, não raciocina e foge. Jean-Pierre Vernant e Pierre Vidal-Naquet, em seu livro Mito e Tragédia na Grécia Antiga volume I e II, comentam:

“[...] Édipo volta do oráculo que lhe revelou seu destino parricida e incestuoso; ele decidiu não mais retornar a Corinto para escapar desse destino (singular confusão, se

${ }^{112}$ SÓFOCLES. Édipo Rei. Tradução do grego Mario da Gama Kury. Rio de Janeiro: Ed. Jorge Zahar. 2001, $5^{a}$ ed. Pág. 58 e 59, versos 928 aos 952. 
ele sabe que estão lá seus pais adotivos; é, ao contrário, voltando para perto deles que ele nada teria a temer; da mesma forma, se Édipo tivesse decidido esposar uma jovem, ele ter-se-ia posto ao abrigo de uma união incestuosa com sua mãe). Ao contrário, partindo para a aventura (entregando-se às livres associações) Édipo vai realizar seu destino (isto é, seu fantasma). Assim, tudo parece ordenar a Édipo, se ele quer evitar a predição, que volte a Corinto, onde não corre perigo. Sua "singular confusão" é um ato sintomático que revela que ele obedece inconscientemente a seu desejo de incesto e parricídio. Mas, para que esta leitura seja fundamentada, é preciso admitir como Anzieu que Édipo sabe, sem sombras de dúvida, que Mérope e Pôlibo, soberanos de Corinto que o criaram como filho adotivo, não são nem sua mãe, nem seu pai, mas simples pais adotivos. Ora, ao longo da peça, até que a verdade se revele, Édipo parece persuadido do contrário. Não apenas uma vez, mas muitas, Édipo afirma, sem a menor dúvida, ser filho de Mérope e de Pôlibo. [...]"113

E assim, Sófocles vai reconstruindo o mitologema, agregando à sua literatura e poesia a versão poética que nos foi legada. Desta forma, ele estabelece para a personagem os meios e os fins a que Édipo estará preso em função do seu livre-arbítrio e não como uma obra do destino. Sobre essa liberdade, Bernard Knox comenta:

\footnotetext{
${ }^{113}$ VERNANT, Jean-Pierre; VIDAL-NAQUET, Pierre. Mito e Tragédia na Grécia Antiga I e II. Tradução de Anna Lia A. de Almeida Prado, Filomena Yoshie Hirata Garcia e Maria da Conceição M. Cavalcante. São Paulo: Ed. Perspectiva. 1999. Pág. 65.
} 


\begin{abstract}
"[...] Nenhuma quantidade de riqueza simbólica consciente, subconsciente ou inconsciente - poderia criar excitação dramática numa peça que não possua prérequisitos essenciais de livre-arbítrio e responsabilidades humanos. A tragédia deve ser auto-suficiente: isto é, a catástrofe deve ser resultado da livre decisão e da ação (ou inação) do protagonista trágico. [...]"114
\end{abstract}

Liberdade de ação que lhe custará muito caro. Édipo segue seu rumo sem sentido contrário ao de Corinto, pretende, na sua inconformação de filho adotivo, fugir da sua maldição oracular.

Continuando seu relato para Jocasta, diz que estava calmo (acreditamos que não). Afinal, temos um jovem que descobriu ser filho de uma maldição terrível, deixou de ser adorado como príncipe de Corinto, trocou a realeza pelo desterro e pela miséria, e está calmo, despreocupado? No mínino estava arrebatado por uma cólera sem limites, o que se afirma no texto seguinte:

Édipo

"[...] Seguia despreocupado a minha rota;

quando me aproximei da encruzilhada tríplice

vi um arauto à frente de um vistoso carro

\footnotetext{
${ }^{114}$ KNOX, Bernard. Édipo em Tebas: o Herói Trágico de Sófocles e seu Tempo. Tradução de Margarida Goldsztyn. São Paulo: Ed. Perspectiva. 2002. Pág. 03.
} 
correndo em minha direção, em rumo inverso;

no carro viajavam um homem já maduro

com a compleição do que me descreveste há pouco.

O arauto e o próprio passageiro me empurraram

com violência para fora do caminho.

Eu, encolerizado, devolvi o golpe

do arauto; o passageiro, ao ver-me reagir

aproveitou o momento em que me aproximei

do carro e me atingiu com um dúplice aguilhão,

de cima para baixo, em cheio na cabeça.

Como era de esperar, custou-lhe caro o feito;

no mesmo instante, valendo-me do meu bordão

com esta minha mão feri-o gravemente.

Pendendo para o outro lado, ele caiu.

E creio que também matei seus guardas todos.

Se o viajante morto era Laio,

quem é mais infeliz que eu neste momento?[...]"115

O terror que se apossa de Édipo é inevitável, ele decretou a expulsão do assassino e do ser impuro que vive em Tebas, não importando se era tebano ou estrangeiro como afirma Tirésias posteriormente. Agora ele se vê julgado e amaldiçoado por ele próprio e

115 SÓFOCLES. Édipo Rei. Tradução do grego Mario da Gama Kury. Rio de Janeiro: Ed. Jorge Zahar. 2001, 5ª ed. Pág. 59, versos 956 aos 975. 
terá que ser expulso de Tebas. Seu juramento será inquebrável. Suas virtudes não permitirão que ele mude de idéia. Age como um herói e nisso residem seus maiores valores humanos.

Até esse momento, o texto de Sófocles não impõe nada a respeito do incesto, tudo gira em torno da morte de Laio, da união de Édipo com a ex-esposa do rei e do exílio de Édipo para outras terras, e o rei completa:

\section{Édipo}

“[...] não poderei jamais ver os meus

nem pôr de novo os pés no chão de minha pátria, pois se o fizesse os fados me compeliriam

a unir-me à minha mãe e matar o rei Pôlibo, meu pai, a quem eu devo a vida e tudo mais! [...]"116

Ou seja, ele ainda persiste na idéia de que seus pais verdadeiros são os reis de Corinto, qualquer outro dado diferente não foi acatado por Édipo a não ser confirmar com o pastor que fugiu dos bandoleiros se os assassinos de Laio eram vários ou apenas um homem.

\footnotetext{
116 SÓFOCLES. Édipo Rei. Tradução do grego Mario da Gama Kury. Rio de Janeiro: Ed. Jorge Zahar. 2001, 5ª ed. Pág. 59, versos 987 aos 991.
} 
Esse guarda que fugiu se chama "Menetes, o fiel servo de Laio que havia exposto Édipo, "117 e que será, mesmo sendo uma personagem episódica, um dos elementos fundamentais no final da trama. Seu nome não é revelado por Sófocles (afinal, ele não passa de um mero pastor de rebanhos que um dia foi o guarda fiel de Laio e expositor da criança no monte Citerão), mas ainda não é o momento de abordarmos tais assuntos neste trecho, pois Menetes ou o guardador de rebanhos voltará quando o posicionarmos frente a Édipo e Jocasta. Então daremos ao mensageiro de Corinto a devida importância.

O livre-arbítrio que se revela na personagem de Édipo não é apenas a inconsequiência dos seus atos, mas a desmitificação dos deuses perante o novo pensamento do homem ateniense que possui o dom da palavra. Apesar da existência constante dos deuses na palavra do coro, aqui eles são representados por oráculos e adivinhos, e é nesse confronto de novas idéias que estão surgindo que o homem cambaleia entre as verdades do sagrado e as novas leis instituídas. O oráculo e os deuses existem, mas seus valores também são questionados diante das novas idéias que vão surgindo no seio da vida cotidiana do homem ático, e Édipo é o porta-voz deste novo pensamento e atitude.

Jeam-Pierre Vernant, em oposição ao complexo de Édipo estudado e difundido por Freud, esclarece à luz da psicologia histórica que:

\footnotetext{
${ }^{117}$ Segundo a fábula 67 de Higino este servo se chamava Menetes e foi responsável pela exposição de Édipo. Trecho encontrado em Junito de Souza Brandão, no volume III de Mitologia Grega. Página 244. Edição da Vozes, Rio de Janeiro em 1993.
} 
“[...] A matéria da tragédia não é mais então um sonho, posto como uma realidade estranha à história, mas o pensamento social próprio da cidade do século $\mathrm{V}$, com as tensões, as contradições que surgem nela, quanto a chegada do direito e as instituições da vida política questionam no plano religioso e moral, os antigos valores tradicionais: estes mesmos que a lenda heróica exaltava, donde a tragédia toma seus temas e suas personagens, não mais para glorificá-las, como fazia ainda a poesia lírica, mas para discuti-los publicamente, em nome de um ideal cívico, diante dessa espécie de assembléia ou tribunal populares que é um teatro grego [...]"118,

O que remete exatamente a este momento da peça, onde Édipo é a voz de Sófocles camuflada numa espécie de parábase inserida no contexto da tragédia.

Para horror da platéia e coragem do rei, os oráculos estão mentindo, equivocados, confusos, pois nada representam para Édipo. É a palavra do homem que importa, pois ele a domina e é o senhor da verdade pautada nas leis do direito grego. Mas Jocasta insiste no seu relato e acrescenta:

\footnotetext{
${ }^{118}$ VERNANT, Jean-Pierre; VIDAL-NAQUET, Pierre. Mito e Tragédia na Grécia Antiga I e II. Tradução de Anna Lia A. de Almeida Prado, Filomena Yoshie Hirata Garcia e Maria da Conceição M. Cavalcante. São Paulo: Ed. Perspectiva. 1999. Pág. 55.
} 
Jocasta

"Ele falou exatamente como eu disse

e agora não irá mudar o seu relato.

Toda a cidade pôde ouvi-lo, além de mim.

Se, entretanto, ele afastar-se das palavras

já divulgadas, inda assim não provará

que o crime perpetrado contra Laio há tempo

corresponde à predição oracular,

pois Febo declarou que ele terminaria

seus dias morto pelas mãos de um filho meu.

Mas Laio não morreu golpeado por meu filho;

meu pobre filho faleceu antes dele.

Também, de hoje em diante não olharei

à esquerda ou à direita em busca de presságios."119

Como também se lê nas últimas palavras de Jocasta em não acreditar mais em presságios, a mulher, mesmo destituída de palavra de voto, é inserida por Sófocles nesse novo contexto social e político em que se envereda no pensamento e convívio da sociedade ateniense.

${ }^{119}$ SÓFOCLES. Édipo Rei. Tradução do grego Mario da Gama Kury. Rio de Janeiro: Ed. Jorge Zahar. 2001, 5ª ed. Pág. 60 e 61, versos 1012 aos 1024. 
Mas, seguindo o relato de Jocasta, o que ela não sabia era que Menetes, o pastor de Laio, havia mentido. Quando chegou e viu Édipo ocupando o trono do antigo rei, implorou à rainha que o mandasse para bem longe da cidade para cuidar dos rebanhos. É evidente. Se ele não fizesse isso, a tragédia de Sófocles terminaria ali mesmo, no reconhecimento do novo rei e assassino. Mas não podemos esquecer que ele era um escravo, portanto não tinha o poder da palavra e nem de decisões importantes, pois estas sempre couberam aos gregos e não a um escravo. Mesmo assim pediu para partir, desaparecer da vista de todos. Menetes tomou tal atitude não para favorecer Édipo, mas para ocultar sua mentira e vergonha e por não ter assassinado a criança quando Laio a entregou aos seus cuidados.

Se Jocasta sabia ou não de toda a verdade desde o momento em que se casou com Édipo não podemos inferir desse dado, no entanto mais uma informação surge a partir do comentário da própria rainha sobre o pastor de Laio:

\section{Jocasta}

"[...] Ao voltar, vendo-te no lugar de Laio, tomou-me as mãos e suplicou-me que o mandasse aos campos para apascentar nossos rebanhos, pois desejava estar bem longe da cidade. Fiz-lhe a vontade, pois o servo parecia 


\section{merecedor de recompensa inda maior. "120,}

E a rainha permitiu sem questionar absolutamente nada? O fato é que o pastor teve de imediato o reconhecimento do assassino de Laio e possivelmente, em função da sua semelhança com o rei, pôde identificar que aquela era a criança que ele deixou sobreviver. Então ele procura a rainha para deixar a cidade e ir para o campo ao invés de procurar o rei. Por quê? Ele mantinha algum tipo de segredo com a rainha ou apenas teria medo de Édipo identificá-lo como um dos fugitivos? Será que os três mantiveram a mentira dos fatos para ocultar os incidentes? Não podemos afirmar essa colocação, mas torna-se mais uma especulação destas relações repletas de mistérios.

Apesar de ser uma especulação da nossa parte sobre a atitude do pastor, não podemos ignorar os estudos da historiografia, quando esta estabelece as relações sociais entre escravos e gregos na Grécia antiga.

É sabido que os escravos não tinham direito algum nas assembléias a não ser quando fossem chamados para algum tipo de depoimento, casos raros esses, pois suas palavras não tinham grande valor. Então, a melhor atitude para Menetes seria ficar de boca fechada e distante de toda a situação existente a partir daquele momento, afinal ele viu Édipo matar o rei e sua comitiva. Mentiu a Jocasta sobre a verdadeira ordem dos fatos, e

\footnotetext{
${ }^{120}$ SÓFOCLES. Édipo Rei. Tradução do grego Mario da Gama Kury. Rio de Janeiro: Ed. Jorge Zahar.
} 2001, 5ª ed. Pág. 57, versos 906 aos 911. 
talvez, devido à notória semelhança entre Édipo e Laio, ele possa ter relembrado de todo o passado.

Foi ele, segundo o texto de Sófocles, quem levou a criança para ser assassinada no monte Citerão ou deixá-la exposta, mas não conseguiu fazer tamanha atrocidade e a deu ao pastor Forbas, da cidade de Corinto, acreditando que o pastor "a conduziria a um lugar distante de onde era originário"121 . De fato isso ocorreu, mas o pastor cuidou de seus ferimentos e o levou até a corte dos reis de Corinto, onde Édipo viveu toda a sua infância e adolescência.

O que o pastor não esperava era que a criança se salvasse e voltasse um dia para tomar posse do seu trono, revelando todas as suas mentiras e omissões e tornando-o testemunho vivo de um desfecho tão violento e fatídico.

Édipo, esse homem, símbolo de uma Arete reconstruída sobre as grandes ações dos heróis míticos, nada teme. Seus vacilos não são erros, são reflexos das novas ações do homem do século V a.C. que se sente na obrigação de saber o todo, de estar no centro de tudo e ser o elo entre a sociedade, estado e religião.

${ }^{121}$ SÓFOCLES. Édipo Rei. Tradução do grego Mario da Gama Kury. Rio de Janeiro: Ed. Jorge Zahar. 2001,

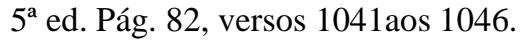


Essa nova visão da humanidade ateniense é que permite que o rei, representante da democracia de Atenas, se engendra para a consumação e conhecimento do todo. Ele não é o tirano, é o estrategista que observa a sociedade e nela se infiltra como seu representante maior no jogo dos interesses políticos, na camuflagem do rei soberano e ideal. Mas, para ser encarado como tal, tem que agir de acordo com os princípios mais elevados de caráter.

Sófocles, um homem que percebeu e entendeu sua época de maneira singular; que teve e esteve na companhia direta o amigo e estrategista Péricles; que, além de ter ocupado diversos cargos públicos, também foi um estrategista, conseguiu reunir todos esses elementos e registrá-los na personagem de Édipo e em toda a sua tragédia.

Sendo assim, seria inevitável que Édipo agisse indiferente a esse novo mundo que despontava. Afinal, o que era o teatro grego, uma mera diversão para todos? Não, o gênero trágico surgiu no fim do século VI a.C. e desapareceu antes de findar o século V a.C. e, em se tratando de tragédia grega, Vernant diz o seguinte:

"[...] Se se trata de um texto trágico, como Édipo-Rei, a análise linguiística, temática, dramática, em cada nível do estudo, desemboca em um problema mais vasto: o do contexto - histórico, social, mental - que dá ao texto todo seu peso de significação. É, com efeito, em referência a esse contexto geral que se desenha a problemática trágica dos gregos; e é somente no quadro dessa problemática 
(que supõe, ligados a um certo estado de sociedade, num campo ideológico definido, modos de pensamento, formas de sensibilidade coletiva, um tipo particular de experiência humana) que a comunicação se estabelece entre o autor e seu público do século $\mathrm{V}$; levando em conta esse contexto e esse quadro é que, para o intérprete de hoje, todos os valores significantes, todos os traços pertinentes do texto se destacam. Uma vez terminado este trabalho de decifração do sentido, está-se, então, em condição de visar aos conteúdos psicológicos, às reações dos espectadores atenienses face ao drama, de definir sobre eles o "efeito trágico".[...]"122

Esta situação é a que corresponde, se vê e se reproduz nas atitudes da personagem de Édipo na tragédia de Sófocles, que persiste na sua busca para concretizar a catástrofe exigida na tragédia, nesta assembléia e julgamento teatral instaurado pelo autor e faz sentido nessa busca, que parece ser insana, mas na verdade não é, pois será nesta aparente insanidade que a catástrofe tem que se realizar e produzir seu efeito transformador, curador, social, político e religioso.

Todas as discussões, advertências e orações foram em vão, até que aparece o mensageiro de Corinto, o pastor Forbas, o amigo do pastor de Laio de há muito tempo. O

\footnotetext{
${ }^{122}$ VERNANT, Jean-Pierre; VIDAL-NAQUET, Pierre. Mito e Tragédia na Grécia Antiga I e II. Tradução de Anna Lia A. de Almeida Prado, Filomena Yoshie Hirata Garcia e Maria da Conceição M. Cavalcante. São Paulo: Ed. Perspectiva. 1999. Pág. 55.
} 
pastor que salvou a criança exposta, que cuidou dos ferimentos nos pés traspassados e depois a levou até Corinto.

Ele, o guardador de rebanhos, aparentemente uma personagem insignificante na peça é a outra metade do quebra cabeça. Forbas, o pastor de Corinto, surge na simplicidade de um homem "guiador" de rebanhos, e não num apoteótico Febo pairando, com seu carro de fogo, nas alturas do teatro de Dioniso. Mais uma vez a genialidade do autor cede espaço a sua criação espetacular do humano dentro da tragédia, colocando um homem comum, no centro da assembléia para estabelecer a peripécia e concretizar o reconhecimento de Édipo.

Jocasta, que estava em súplicas no altar de Apolo Lício, é quem recebe o mensageiro da esperança - melhor dizer, da justiça. Forbas não é apenas um mero mensageiro. Ele, camuflado na personagem de um pastor, é a outra parte do testemunho. E Sófocles, ardilosamente, coloca no texto do pastor o encaixe e resolução da trama, para concretizar o mito. Com sua chegada, a assembléia está formada, falta apenas a última testemunha, o pastor de Laio, que logo será trazido ao tribunal do teatro para completar o desfecho.

Forbas traz a miraculosa informação: Pôlibo, rei de Corinto e pai de Édipo, morreu e o povo deseja que ele retorne para se apossar do trono, que também lhe pertence. A rainha se enche de alegria e o alivio toma conta do seu espírito amargurado. Não há 
mais o que temer, não foi seu marido quem matou o pai. Para ela tudo está consumado e resolvido. Os oráculos mentiram e não são mais motivos de atenção para ambos.

No entanto, Édipo teme que mesmo com o pai morto ele possa se unir incestuosamente com sua mãe Mérope, que ainda vive. Sem delongas, o mensageiro que ouve todo o diálogo esclarece que Édipo não tem com o que se preocupar, pois não é filho de Pôlibo e Mérope, confirmando que é filho adotivo do casal, que foi ele que entregou Édipo, ainda criança, para ser criado pela realeza de Corinto.

O que era alívio virou tormenta. A mínima pausa de paz transformou-se em guerra. O que era escuridão revela-se em claridade e a busca de Édipo está por findar. O terror vai aos poucos liberando suas negras expressões, mas o rei, resoluto, insiste na peripécia e no reconhecimento da situação:

\section{Édipo}

"[...] E antes de dar-me a ele havias-me comprado, Ou por acaso me encontraste abandonado?

\section{Mensageiro}

Achei-te lá no Citéron, num vale escuro.

\section{Édipo}

\section{Por que motivos percorrias tais lugares?}

\section{Mensageiro}


Levava meu rebanho ao pasto, nas montanhas.

\section{Édipo}

Eras pastor, então, a soldo de um senhor?

\section{Mensageiro}

Era, mas te salvei naquele tempo, filho.

\section{Édipo}

E como estava eu quando me descobriste?

\section{Mensageiro}

Lembro-me bem de teu estado deplorável;

teus tornozelos inda testemunham isso.

\section{Édipo}

Fazes-me recordar antigas desventuras!...

\section{Mensageiro}

Desamarrei teus tornozelo traspassados...

Édipo

Segue-me esse defeito horrível desde a infância.

\section{Mensageiro}

Teu próprio nome te relembra esse infortúnio. [... $]^{123}$

Após esta informação, Édipo não hesita, ele quer a presença do pastor a qualquer custo, "eis o momento de aclarar-se tudo"124 completa, sentenciando seu funesto

${ }^{123}$ SÓFOCLES. Édipo Rei. Tradução do grego Mario da Gama Kury. Rio de Janeiro: Ed. Jorge Zahar. 2001,

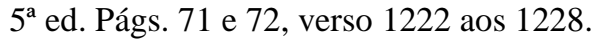


destino. Jocasta, que até então se felicitava com a notícia do mensageiro de Corinto, se aterroriza diante dos fatos. Ela também se desespera e procura em vão afastar Édipo da verdade. Não há mais o que se esconder, a confirmação da maldição do oráculo será a sentença que se abaterá sobre ela também.

O mito, a maldição, as mentiras e omissões surgem no horror estampado na trágica máscara de Jocasta. Ela, que sempre soube da verdadeira história se lança ao desespero "ai de mim! Ai de mim! Infeliz! Eis o nome que hoje mereces! Nunca mais ouvirás outro!" 125 e retira-se precipitadamente em direção ao palácio.

Seguindo o texto de Sófocles e a persistência de Édipo, o velho pastor de Laio é trazido diante do palácio para ser interrogado pelo rei. Se, ainda hoje, tal cena nos remete ao fundo das nossas emoções por saber que Édipo saberá da verdade e mergulhará num abismo sem retorno, imagine-se a mesma cena representada no século $\mathrm{V}$, onde o mito sobrevive, no lar, nas ruas e no teatro, engrandecido por toda a encenação existente na época; com certeza o silêncio tomaria conta de todos os espaços. O coro que antes dançava o hiporquema ficaria estarrecido diante do homem que chegava. As danças e os cantos cessariam. O espaço teatral tornar-se-ia o palco do julgamento final. A platéia, atônita, desesperada, silenciosa, ouvindo as inquirições de Édipo desprendiam-se de suas almas e o êxtase seria o bálsamo consolador das almas aflitas. Édipo, agigantado sob as

${ }^{124}$ SÓFOCLES. Édipo Rei. Tradução do grego Mario da Gama Kury. Rio de Janeiro: Ed. Jorge Zahar. 2001, $5^{\text {a }}$ ed. Pág. 73, verso 1241.

${ }^{125}$ SÓFOCLES. Édipo Rei. Tradução do grego Mario da Gama Kury. Rio de Janeiro: Ed. Jorge Zahar.

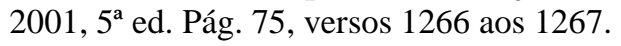


vestimentas da realeza torna-se o mito em vida, o verbo em carne e transforma ilusão em realidade e toda época heróica dos séculos anteriores tomam conta da cena. O real e o imaginário se amalgamam para construir a mimese catártica que gradativamente iria penetrando o homem grego para levá-lo a catarse mais pura de suas emoções.

O diálogo da inquisição é duro, certeiro como a flecha de Apolo. O rei não mede as conseqüências diante do velho pastor que implora para não esclarecer a verdade. Verdade já explicitada por Tirésias. Mas Édipo quis ouvir e saber da fonte humana, não dos oráculos. Também não deu ouvidos às advertências de sua desmedida proferida pelo coro:

\section{Coro}

"[...] O orgulho é o alimento do tirano;

quando ele faz exagerada messe

de abusos e temeridades fátuas

inevitavelmente precipita-se

dos píncaros no abismo mais profundo

de males de onde nunca mais sairá. [...."126

Mas nada o detém. Sua atitude como representante de Tebas é a busca da verdade, seja ela a pior que for. Bernard Knox diz que "sua ação é rápida como um

${ }^{126}$ SÓFOCLES. Édipo Rei. Tradução do grego Mario da Gama Kury. Rio de Janeiro: Ed. Jorge Zahar. 2001, $5^{a}$ ed. Pág. 61 e 62, versos 1041aos 1046. 
raio: uma vez concebida, não é tolhida pelo medo ou pela hesitação; antecipa-se a conselho, aprovação ou dissentimento" ${ }^{\text {127, }}$, e assim segue no seu desejo de justiça, mesmo que ela já esteja cega onde o único réu será o próprio Édipo.

Temos de um lado o oráculo e Tirésias, ambos representação do sagrado na terra; e de outro Creonte, Jocasta, Forbas, Menetes e o coro, representantes do povo na assembléia do júri popular, mas condicionados e subordinados à superioridade dos deuses, que ainda persistem na tragédia de Sófocles. Ambos lados estão prontos para a apoteótica catástrofe do casal incestuoso e do filho parricida. A justiça tarda mas não falha, diz o provérbio do direito romano, e sobre Édipo ela lança toda a sua verdade. As Fúrias completam sua função de vingadoras e Édipo, o salvador de Tebas, paga o doloroso tributo da sua maldição.

Menetes é o enviado e esclarecedor da verdade, a prova humana que Édipo tanto deseja. Está na tribuna de Tebas sofrendo angustiado diante das interrogações de Édipo:

\section{Pastor}

[...] Não, pelos deuses, rei! Não me interrogues mais! Édipo Serás um homem morto se não responderes!

${ }^{127}$ KNOX, Bernard. Édipo em Tebas: o Herói Trágico de Sófocles e seu Tempo. Tradução de Margarida Goldsztyn. São Paulo: Ed. Perspectiva. 2002. Pág. 11. 


\section{Pastor}

Ele nascera... no palácio do rei Laio!

Édipo

Simples escravo, ou então... filho do próprio rei?

\section{Pastor}

Quanta tristeza! É doloroso de falar!

Édipo

Mas doloroso de escutar, mas te negues.

Pastor

Seria filho dele, mas tua mulher

Que deve estar lá dentro sabe muito bem

a origem da criança e pode esclarecer-nos.

Édipo

Foi ela mesmo a portadora da criança?

\section{Pastor}

Sim ,meu senhor; foi Jocasta, com as próprias mãos.

Édipo

Por que teria ela agido desse modo?

Pastor

Mandou-me exterminar a tenra criancinha.

Édipo

Sendo ela a própria mãe? Não te pareces incrível?

Pastor 
Tinha receios de uns oráculos funestos.

Édipo

E quais seriam os oráculos? Tu sabes?

Pastor

Diziam que o menino mataria o pai.

Édipo

Por que deste o recém nascido a este ancião?

Pastor

Por piedade, meu senhor; pensei, então,

Que ele o conduziria a um lugar distante

De onde era originário; para nosso mal

Ele salvou-lhe a vida. Se és quem ele diz,

Julgo-te o mais infortunado dos mortais! [... $]^{\text {\$128 }}$

Jocasta já havia retornado para dentro do palácio em total desespero. Após a confirmação dos fatos pelo pastor de Laio, o rei, que até agora era ágil, poderoso e senhor de tudo, caminha a passos lentos em direção ao palácio. Depois de tanto tempo ele se encontrou e se reconheceu. Desventurado, o filho da sorte, maldito deste o seu nascimento, na tentativa de salvar a cidade da peste, incide em seu pior destino na fatídica descoberta de sua verdadeira origem. Ou seja, segundo a tragédia de Sófocles,

128 SÓFOCLES. Édipo Rei. Tradução do grego Mario da Gama Kury. Rio de Janeiro: Ed. Jorge Zahar.

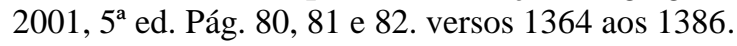


ele é o assassino do próprio pai, filho de Jocasta e consequentemente pai de seus próprios irmãos.

O criado retorna do palácio, sua expressão traz o assombro das piores imagens que alguém possa ter visto. Oculta da platéia, atônita e aterrorizada, umas sucessões de acontecimentos desencadearam as piores imagens criadas no imaginário inconsciente e consciente do público. O relato do criado é a confirmação da catástrofe e da catarse criada por Sófocles em sua magistral tragédia.

Talvez, em nenhuma outra época, uma tragédia tenha alcançado tamanha força dramática no teatro grego. A preciosidade, esmero, polimento, decodificação do mito edipiano é, nesta obra de Sófocles, daquilo que nos restou, a mais preciosa reconstrução de efeito trágico que acontecia nas encenações das tragédias gregas do século $\mathrm{V}$ a.C., e o relato detalhado do criado é a confirmação dessa expressão artística impar existente num determinado período da humanidade:

\section{Criado}

“Com as próprias mãos ela deu fim à existência. talvez fosse melhor poupar-vos dos detalhes mais dolorosos, pois os fatos lastimáveis não se desenrolaram em vossa presença. Contudo sabereis o que sofreu Jocasta, até onde eu puder forçar minha memória. Quando a infeliz transpôs a porta do seu quarto lançou-se como uma louca ao leito nupcial; 
com as duas mãos ela arrancava os cabelos.

Depois fechou as portas violentamente, chamando aos gritos Laio há tanto tempo morto, gritando pelo filho que trouxera ao mundo para matar o pai e que destinaria a ser mãe de filhos de seu próprio filho, se merecessem esse nome. Lamentava-se no leito mesmo onde ela havia dado à luz - dizia a infeliz - em dupla geração Aquele esposo tido de seu próprio esposo E os outros filhos tidos de seu próprio filho! Como em seguida ela morreu, não sei contar. Aos gritos Édipo acorreu, mas também ele não pode presenciar a morte da rainha. Os nossos olhos não se despregavam dele correndo como um louco em todos os sentidos, pedindo em altos brados que um de nós lhe desse logo um punhal, gritando-nos que lhe disséssemos onde se achava sua esposa (esposa não, mas a mulher de cujo seio maternal saíram ele próprio e todos os seus filhos). Em seu furor não sei que deus fê-lo encontrá-la (não foi nenhum de nós que estávamos por perto). Então, depois de dar um grito horripilante, como se alguém o conduzisse ele atirou-se de encontro à dupla porta: fez girar os gonzos, e se precipitou no interior da alcova.

Pudemos ver, pendente de uma corda, a esposa; o laço retorcido ainda a estrangulava. Ao contemplar o quadro, entre urros horrorosos o desditoso rei desfez o laço 
que a suspendia; a infeliz caiu por terra.

Vimos, então, coisas terríveis. De repente

o rei tirou das roupa dela uns broches de ouro

que as adornavam, segurou-os firmemente,

sem vacilação furou os próprios olhos,

gritando que eles não seriam testemunhas

nem de seus infortúnios nem de seus pecados:

"nas sombras em que viverei de agora em diante",

dizia ele, "já não reconhecereis

aqueles que não quero mais reconhecer!"

Vociferando alucinado, ainda erguia

as pálpebras e desferia novos golpes.

$O$ sangue que descia em jatos de seus olhos

molhava toda a sua face, até a barba;

não eram simples gotas, mas uma torrente,

sanguinolenta chuva em jorros incessantes.

São ele e ela os causadores desses males,

e os infortúnios do marido e da mulher

estão inseparavelmente entrelaçados.

Ambos provaram antes a felicidade,

herança antiga; hoje lhes restam só gemidos,

vergonha, maldição e morte, ou, em resumo,

todos os males, todos, sem faltar um só!"129

O relato do criado é de tamanha verossimilhança que se torna possível não somente entender a cena trágica, mas ver a cena em nosso imaginário. As minúcias como se deram os acontecimentos e o desencadeamento das ações de Édipo e Jocasta é aos nossos olhos motivo de pena, compaixão. Imagine num povo que acreditava em seus

${ }^{129}$ SÓFOCLES. Édipo Rei. Tradução do grego Mario da Gama Kury. Rio de Janeiro: Ed. Jorge Zahar. 2001,

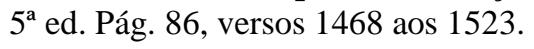


mitos, em seus heróis com suas façanhas de super-heróis, e na grandeza de seu povo. Os atenienses que lotavam o teatro iriam do céu ao inferno em segundos conforme se estabelece a catarse descrita por Aristóteles. Assim, vemos e entendemos nesse trecho, que o maravilhoso trágico se desnuda na concepção teatral do mito de Édipo: seu ato parricida e sua relação incestuosa com Jocasta têm seu verdadeiro fim artístico. A obra de Sófocles jamais alcançaria tamanha grandeza se ele não se opusesse à raiz original do mito.

Historicamente o mitologema edipiano está adulterado na sua origem, mas não perde sua função natural e ganha em muito da concepção teatral criada por Sófocles. O que nos leva a dizer que se Euricléia (a primeira esposa de Laio) fosse a personagem da mulher na tragédia, a catástrofe não aconteceria. Mas, a partir do momento em que o gênio tragediógrafo cria a personagem de Jocasta como única esposa de Laio, estabelece-se o incesto entre ambos e o parricídio para Édipo. A relação trágica torna-se algo monumental entre as duas personagens. Dessa forma, o teatro grego concretiza a função social, religiosa e política a que foi destinado.

Após o relato do Criado, Édipo retorna e expõe seus olhos cegos e sua postura deplorável diante de todos. Digno de piedade, ele nos compadece com sua terrível desgraça e dor insuportável. Réu de seu próprio veredicto terá que abandonar Tebas, e mais uma vez claudicar por terras estranhas. Lamenta sua desventura; questiona sua sabedoria e sua cegueira diante dos deuses porque somente agora ele pôde ver as atrocidades cometidas por ele mesmo. Assume suas culpas, perdoa os ofendidos e pede 
seu exílio. Mas para Creonte ele somente partirá depois que procurar Febo e saber qual atitude deve tomar. Enquanto isso, Édipo ficará exilado no palácio, até o dia em que partirá acompanhado por sua filha Antígona para o distrito de Colono e lá ter o seu descanso final. 
“Quem não se satisfaz com um quinhão normal de vida e deseja um maior, parece-me em verdade um insensato.

Dias sem numero nunca reservam a ninguém nada mais que dissabores mais próximos da dor que da alegria.

Quanto aos prazeres, não os discernimos e nossa vista os buscará em vão logo que para nossa desventura chegamos aos limite prefixado.

E desde então o nosso alivio único será aquele que dará a todos o mesmo fim, na hora de chegar de súbito o destino procedente do tenebroso reino onde não há cantos nem liras, onde não há danças - ou seja, a Morte, epílogo de tudo. 
Não acredito que concluímos uma pesquisa sobre o Édipo Rei de Sófocles, acredito que concluímos mais uma, entre tantas já realizadas. Por que se nos posicionarmos dessa forma, colocaremos, acima de tudo, nossa prepotência. E se assim agirmos, estaremos indo contra todo nosso estudo, porque não produzimos esse material para cristalizar uma idéia e impô-la como verdade absoluta, mas adicionamos mais uma fonte de pesquisa para aqueles que buscam a origem do teatro ocidental, mais um estudo que possa colaborar no campo das artes cênicas e no entendimento do teatro grego no século V a.C., utilizando as tragédias gregas como fonte de fundamental importância para o entendimento do fazer teatral em pleno século XXI.

Apresentar mais um estudo sobre o mito de Édipo através de estudos comparativos das diversas áreas das Ciências Humanas, manipulando seus diversos pontos de vista, não é obra fácil de concluir, pois nos apropriamos de outros pensamentos para elaborarmos o nosso, e nesse sentido, vez ou outra, fomos obrigados a questionar alguns pensadores com os quais trabalhamos.

Em nenhum momento diminuímos a imagem de, Sófocles, Péricles, Édipo ou Jocasta, figuras centrais de nossa dissertação, ao contrário enaltecemos estes seres humanos e mitológicos na revelação de suas atitudes e posturas mediante seus tempos e reflexos de uma época impar na história do teatro mundial, desvelando particularidades e visões que se somam a tantos estudos sobre o mito de Édipo e da tragédia grega do século V a.C. 
Apresentar essa dissertação se nos tornou uma obrigação como estudioso e pesquisador da tragédia Oidipous Tirannus de Sófocles. Ao contrário, na nossa condição de aprendizes do mundo helênico é a gratidão que nos acompanhou em cada pensamento concluído a partir de uma obra tão rica em informações como é Édipo Rei de Sófocles e sua gigantesca colaboração para a história do teatro mundial.

Sófocles não foi apenas um escritor de tragédias, foi um criador de homens e de almas, que com sua sabedoria soube captar as mudanças históricas, econômicas, sociais e políticas em seu período, e transpô-las para a cena teatral com o mesmo polimento que Fídias deu a suas esculturas ou senão superior a ele.

Podemos dizer isso porque suas obras até hoje despertam a curiosidade dos mais importantes estudiosos contemporâneos, que não cessam de encontrar, nas escritas e entrelinhas de suas tragédias, informações preciosas sobre a Grécia antiga. Conteúdos que, mesmo passados mais de vinte e cinco séculos, além de trazer informações do passado, se integram à sociedade do século XXI, tamanha a atualidade das obras.

A genialidade com que Sófocles captou o comportamento do homem ateniense de seu século e o transformou numa persona teatral, agregando-lhe virtudes e defeitos, para serem encenado e depois transformado numa espécie de assembléia e júri, tal qual acontecia na Ágora ateniense, enleva sua capacidade prodigiosa do homem comprometido com os meios e fins que existem numa sociedade que, para isso, se utilizou do teatro como elemento fundamental para discussões e transformações do homem daquele tempo. 
Admirador de Ésquilo, tragediógrafo por natureza e político por excelência, Sófocles esteve ligado diretamente à máquina administrativa de Atenas e dela retirou a fórmula com que fundamenta seu Édipo Rei. Transgride o mito para reescrever a trágica história do rei parricida e incestuoso de sua tragédia, mesmo que para isso tenha que optar apenas por uma variante do mito entre tantas que o mitologema edipiano nos apresenta.

O construtor do herói claudicante tomou da licença poética de que lhe era capaz e eternizou sua tragédia e seu nome através de Édipo. Não que outras tragédias suas não tenham importância; ao contrário, são tão importantes como Édipo. A questão é que Édipo Rei, em função da atualidade nele existente e as diversas interpretações que esta tragédia permite, suscitou nos estudiosos posteriores varias investigações de sua obra, colocando-o no topo de vastas pesquisas dos mais diversificados estudos.

O alcance da peça de Sófocles permitiu que vasculhássemos seu conteúdo mítico e dela elaborássemos nossa dissertação, estabelecendo ligações que não estão apenas no campo do teatro grego, mas, nas relações sociais, religiosas e políticas na poleis grega. Destacamos outros universos que foram agregados à tragédia de Sófocles, reelaborando o mito no contexto pertinente ao século $\mathrm{V}$ a.C.

A partir da elaboração da tragédia Édipo Rei, reorganizada por Sófocles, concluímos que, seguindo inovações do pensamento ateniense no campo do direito e da filosofia grega, a arte teatral passou a refletir essas mudanças que não estando ainda consolidadas no seio da sociedade, exemplifica esta ambigüidade no comportamento da 
sociedade ateniense. $\mathrm{O}$ que também esclarece o questionamento do homem e suas crenças arcaicas sobre os deuses e suas ações sobre esse mesmo homem, colocando-se como responsável por seus próprios atos.

Assim, entre a crença nas divindades e no livre-arbítrio que esse novo homem se descobriu, ele, que até então se posicionava na submissão às divindades, descobre que pode agir por si próprio, mesmo que suas ações possam enveredá-lo pelos torpes caminhos da desventura, do erro ou acerto. Mas se descobre dono de si e passa a agir nesse universo duplo, que ora o confunde e ora o esclarece.

Édipo é o fruto desse pensamento. Na versão escrita por Sófocles ele é o senhor da nova liberdade que afronta os oráculos, os adivinhos e os deuses. Porém, desvendado o seu fim trágico pede socorro aos deuses e ao mesmo tempo os acusa por sua desventura. Esse conflito edipiano é o mesmo conflito estabelecido no seio da sociedade ateniense, onde o homem luta por uma coisa e outra, mas não se encontra em nenhuma delas. E neste universo dramático ele é o homem aflito, duplo e trágico.

Essa liberdade de ações está centrada num período especifico da democracia de Atenas, que corresponde à estruturação de suas leis no final do século VI com o advento de Sólon até perderem seu valor após a guerra do Peloponeso e a total fragmentação da Grécia. Neste momento suas cidades estados se perdem diante destas mesmas leis por eles elaboradas. 
Quando Péricles assume a magistratura em Atenas, estas normas democráticas estavam no apogeu de seus valores e ele, na condição de estrategista que ocupou, fê-las funcionar ainda mais no engenho da maquina administrativa e política de Atenas. Atenas usufrui de benefícios em todas as órbitas, principalmente no campo fértil das artes em geral, desde a reconstrução da Acrópole e embelezamento da cidade, até as grandes festas, no campo fértil que a tragédia grega ocupou durante tal período.

Tendo Péricles, transformado Atenas na magnífica cidade imperial da Grécia, através da utilização das finanças da confederação de Delos, pôde injetar o dinheiro dos contribuintes na realização das grandes obras e na organização de grandes festivais de teatro, as famosas dionisíacas urbanas, valorizando a encenação teatral como nunca antes feito.

No entanto, seu investimento, apesar da contribuição deixada por ele até os dias de hoje, teve um propósito fundamentalmente visado. Na formação do pensamento deste novo homem ateniense da Grécia dos grandes escritores e encenadores das tragédias, teatro, política, democracia e religião passaram a ser fiscalizadas pelo estado. Mediante seus investimentos na cultura, o estado de Péricles passou a manipular o pensamento do homem dessa época, reflexo esse existente na obra Édipo Rei de Sófocles.

Sendo assim, a personagem de Édipo não é apenas o mito do herói tebano encenado no centro do teatro ateniense, mas é a popularização e disseminação das idéias da liberdade do homem frente aos destinos estabelecidos pelos deuses. Ou seja, Édipo é uma espécie de anti-herói, revisitado na tragédia sofocliana, onde seu mito e sua relação 
histórica desde os primórdios do mitologema passam por uma transformação em suas variantes para se estabelecerem uma única vertente do mito, a mais dramática, onde a ação humana é independente e preponderante.

Vasculhando o passado histórico do teatro grego e colhendo novas evidências sobre o herói, podemos acrescentar mais um estudo e uma outra visão sobre os enigmas edipianos, sem mergulhar no campo da psicanálise e sim nos estudos históricos que existem a respeito, a relação trágica com Jocasta e conseqüente o desfecho da obra através das significantes informações existentes na tragédia de Sófocles.

Desta forma, a nova historiografia foi de extrema importância em nosso estudo, onde encontramos claras evidências a que nos propomos nesta dissertação, assim como a revisão de inúmeros trabalhos realizados por autores renomados, que, sem pudores e convictos de suas pesquisas, escreveram sobre o mesmo mito nas mais diversas abordagens, tamanha é a riqueza de informações que o texto da tragédia nos proporciona.

Como enfatizamos inúmeras vezes ao longo do trabalho, podemos observar que o mito de Édipo possui diversas variantes, onde uma delas foi a alavanca propulsora para nossa dissertação. Nesta variante arcaica do mito encontramos uma situação do herói tebano diferenciada da que Sófocles nos legou. Para espanto de muitos, descobrimos que 
Laio teve duas esposas, sendo Édipo filho da primeira esposa e não de Jocasta, com quem Laio se casou em segundas núpcias, após a exposição de Édipo.

Nos deparamos com a figura da rainha Euricléia como primeira esposa de Laio no conteúdo formal especificado por Junito de Souza Brandão na versão original e popular do mito, o que nos levou a questionar a veracidade da obra de Sófocles cristalizada na figura de Jocasta e não de Euricléia. Ou seja, a tragédia sofocliana, em função do período a que foi escrita e encenada, criou uma nova personagem que até então não era existente no mitologema edipiano, o que nos deu margem para vasculhar o mito e dele extrairmos a nossa pesquisa, pautada na versão original do mito e não somente nas informações da tragédia que nos foi legada.

Dessa informação partimos para uma minuciosa decodificação das estruturas sociais e políticas do século $\mathrm{V}$ a.C., que sem dúvida, interferiram na reestruturação da tragédia escrita por Sófocles, onde o autor, tomado por uma licença poética, criou a figura de Jocasta, esposa de Laio e mãe do amaldiçoado filho Édipo. Depois da morte de Laio, Jocasta e Édipo se casam, sem saber do parentesco consangüíneo que os unem.

Nesse reencontro de mãe e filho é que reside a mola trágica da obra sofocliana, não apenas no seu desfecho, mas em todos os episódios que compõem o trágico da obra que se encerra no revés da passagem da fortuna para a desdita, através do 
reconhecimento da falta cometida, onde purgação, expiação, terror e piedade transparecem na cena trágica que opera sua função purificadora.

Ao nosso entender, no mito original estes elementos não aconteceriam, pois Euricléia identificaria o filho de imediato, coisa que não acontece com Jocasta, ainda que exista diversos fatores externos viabilizadores do reconhecimento de Édipo enquanto assassino de Laio. Porém a sabedoria de Sófocles é maior em tudo isso, pois ele não vê o mito apenas como algo lendário a ser encenado, mas como um tribunal ateniense, onde erros e acertos receberão o veredicto da justiça.

Sendo assim, consideramos que nosso estudo tem fundamentação literária e histórica teatral para contribuir para a história do teatro, pois, reunindo as novas informações, acrescentadas a toda bibliografia pesquisada e estudada enaltece em muito a obra literária de Sófocles. Desta forma, esta dissertação propõe uma revisão sobre o mito de Édipo, pautada em informações claras e precisas coletadas para este estudo o que colabora em muito para as ciências modernas.

Desta forma procuramos entender o sentido do destino de Édipo e Jocasta; estabelecemos uma nova visão sobre a obra de Sófocles, sobre o mitologema edipiano e a figura feminina de Jocasta, que sempre esteve a mercê dos estudos trágicos e que, sendo a figura representativa do universo feminino na cena trágica do Édipo Rei, merece mais destaque que o dado à rainha de Tebas. Os estudos tendem a se fixar na figura do Édipo, 
tratando Jocasta como figura passiva, ignorante de seu destino, incapaz de reflexão antes do início da ação.

Esta é a distorção que Sófocles promove no mito. Se Jocasta é a mãe de Édipo, ela sabe que casou com o próprio filho (semelhança com Laio, armas do rei morto, tempos de convivência com o novo marido - tiveram quatro filhos, cumprimento do oráculo, pés traspassados, tortos ou inchados). Se não era mãe, a tragédia perde um de seus pontos mais fortes. O parricídio, ainda que abominável, seria passível de julgamento, como obteve Orestes por seu matricídio.

Ambos foram vítimas, expiatórias ou não, e trazem consigo uma culpa que possa não ser de um rei e de uma rainha, mas de uma forma de governo que, mediante o poder do mito, fez dele um instrumento para educar e manter o status quo de uma cidade cobiçada, poderosa e bélica como foi Atenas.

René Girard posiciona Édipo como vítima expiatória ${ }^{130}$ em função de uma sociedade que precisava da purgação de um indivíduo para sua purificação. Decodificando o texto da tragédia, principalmente no que diz respeito ao mito, suas variantes, suas exceções e nossas especulações, podemos sem dúvida dizer que, como a peste lançada sobre Tebas, Sófocles escreveu uma maravilhosa metáfora sobre o homem ateniense. A partir do momento em que houve a necessidade de purgar e expulsar "essa peste" do organismo da cidade, Édipo foi a representação máxima dessa metáfora e juntamente com ele Jocasta.

${ }^{130}$ GIRARD, René. A Violência e o Sagrado. São Paulo: Paz e Terra. 1990, 2a Ed. Pág. 91. 
Cumpre realçar a majestade a que Sófocles alçou o mito ao promover alterações em sua estrutura arcaica (duas mulheres para Laio). Os recursos dramáticos que levaram Sófocles a suprimir Euricléia e condensar o feminino em Jocasta tornam a obra mais importante, ao alimentar a tragédia e a densidade dramática do conjunto. A história tornou-se fascinante não apenas para o ateniense do século V a.C., mas um mistério e motivo de reflexão para o homem do século XXI. É desnecessário dizer que a opção de Sófocles criou a tragédia da antiga Grécia para entender a psique do homem moderno.

E a genialidade do autor entra por outros caminhos menos explorados em nossa dissertação. Como exemplo a não interferência divina na ação. Apenas oráculos e adivinhos prevêem a tragédia. Mais instigante ainda, deuses são substituídos pelo povo mais humilde. É o criado, que nem nome próprio tem no Édipo Rei, aquele que será a figura chave no desenlace da trama. Mas isso é material para outras dissertações. 


\section{ALTARRIBA, Jordi. Enciclopédia do Patrimônio da Humanidade: Grécia e Chipre.}

Direção geral de Fernando Castillo. Barcelona: Portugal. Ediciones Altaya S.A: 1998.

ARISTÓfANES. As Nuvens. Tradução do grego Mario da Gama Kury. Rio de Janeiro: Jorge Zahar Ed., 2003, $3^{\mathrm{a}}$ ed.

. Só para Mulheres. Tradução do grego Mario da Gama Kury. Rio de Janeiro: Jorge Zahar Ed., 2003, $3^{\text {a }}$ ed.

Um Deus Chamado Dinheiro. Tradução do grego Mario da Gama

Kury. Rio de Janeiro: Jorge Zahar Ed., 2003, $3^{\text {a }}$ ed.

As Vespas. Tradução do grego Mario da Gama Kury. Rio de Janeiro:

Jorge Zahar Ed., 2004, $3^{\mathrm{a}} \mathrm{ed}$.

As Aves. Tradução do grego Mario da Gama Kury. Rio de Janeiro:

Jorge Zahar Ed., 2004, $3^{\mathrm{a}} \mathrm{ed}$.

As Rãs. Tradução do grego Mario da Gama Kury. Rio de Janeiro:

Jorge Zahar Ed., 2004, $3^{\text {a ed. }}$

A Greve do Sexo (Lisístrata). Tradução do grego Mario da Gama

Kury. Rio de Janeiro: Jorge Zahar Ed., 2006, $6^{\text {a }}$ ed.

A Revolução das Mulheres. Tradução do grego Mario da Gama

Kury. Rio de Janeiro: Jorge Zahar Ed., 2006, $6^{\text {a }}$ ed.

A Paz. Tradução do grego Mario da Gama Kury. Rio de Janeiro:

Ediouro, 1964. 
ARISTÓTELES. Poética. Tradução de Eudoro de Souza. Porto Alegre: Editora Globo. 1966.

Política. São Paulo: Editora Nova Cultural, 2004.

Constituição de Atenas. São Paulo: Editora Nova Cultural, 2004.

ARTAUD, Antonin. O Teatro e seu Duplo. São Paulo: Ed. Martins Fontes, 1999, $2^{\text {a }}$ ed.

BERTHOLD, Margot. Historia Mundial do Teatro. Tradução de Maria Paula

Zurawski, J. Guinsburg, Sérgio Coelho e Clóvis Garcia. São Paulo: Ed. Perspectiva, 2001

BOLEN, Jean Shinoda. As Deusas e a Mulher: Nova Psicologia das Mulheres. Tradução de Maria Lydia Remédio. São Paulo: Ed. Paulus, 1990, $5^{\text {a }}$ ed.

BORBA FLORENZANO, Maria Beatriz. Nascer, Viver e Morrer na Grécia Antiga. São Paulo: Atual Editora, 1996.

BRANDÃO, Junito de Souza. Teatro Grego: Tragédia e Comédia. Rio de Janeiro: Ed. Vozes, 2001, $8^{\text {a }}$ ed.

. Mitologia Grega. Rio de Janeiro: Ed. Vozes, 1993, 5ª ed., Vol. I . Mitologia Grega. Rio de Janeiro: Ed. Vozes, 1993, $5^{\text {a }}$ ed., Vol. II. Mitologia Grega. Rio de Janeiro: Ed. Vozes, 1993, 5ª ed., Vol. III.

CAMPBELl, Joseph. O Herói de Mil Faces. Tradução de Adail Ubirajara Sobral. São Paulo: Editora Pensamento. 2007.

. O Poder do Mito. Tradução de Carlos Felipe Moisés. São Paulo: Palas

Atena. $1990,11^{\mathrm{a}} \mathrm{ed}$.

CARLSON, Marvin. Teorias do Teatro: Estudo Histórico-Crítico dos Gregos à Atualidade. Tradução de Gilson César Cardoso de Souza. São Paulo: Ed. Unesp, 1997. 
COUlangeS, Fustel de. A Cidade Antiga: Estudos Sobre o Culto, o Direito, as Instituições da Grécia e de Roma. São Paulo: Ed. Hemus: 1975.

DABDAD TRABULSI, José Antonio. Dionisismo, Poder e Sociedade na Grécia até o fim da Época Clássica. Belo Horizonte: Ed. UFMG. 2004.

\section{M.G. DURANDO, Furio. Grandes Civilizações do Passado: A Grécia Antiga.}

Tradução de Carlos Nougué. Direção geral de José Luis Sanchez e Meritxell Almarza. Barcelona: Portugal. Edizione White Star e Folio: 2005.

EGIDATI, Bárbara; LUCCA, Rita. Grande História Universal: Época Clássica. Direção geral de Elizabetta Bovo. Barcelona: Portugal. Ediciones Folio S.A. 2006.

ELIADE, Mircea. Mito e Realidade. São Paulo: Ed. Perspectiva. 2004, $6^{\text {a }}$ ed.

ÉSQUILO. Agamêmnon. Tradução do grego Mario da Gama Kury. Ed. Rio de Janeiro: Jorge Zahar. 1991, $2^{\mathrm{a}}$ ed.

. Coéforas. Tradução do grego Mario da Gama Kury. Ed. Rio de Janeiro: Jorge Zahar. 1991, $2^{\mathrm{a}}$ ed.

. Eumênides. Tradução do grego Mario da Gama Kury. Ed. Rio de Janeiro: Jorge Zahar. 1991, $2^{\mathrm{a}}$ ed.

Os Persas. Tradução do grego Mario da Gama Kury. Rio de Janeiro: Ed. Jorge Zahar. 2004. $5^{\mathrm{a}}$ ed.

. Prometeu Prisioneiro. Tradução de Trajano Vieira. São Paulo: Ed. Perspectiva. 1997.

. Os Sete Contra Tebas. Tradução de Donaldo Schüler. Rio Grande do Sul. Coleção L\&PM Pocket. 1991. 
EURÍPEDES. Medéia. Tradução do grego Mario da Gama Kury. Rio de Janeiro: Ed. Jorge Zahar. 2001, $5^{\text {a }}$ ed.

Hipólito. Tradução do grego Mario da Gama Kury. Rio de Janeiro: Ed. Jorge Zahar. 2001, $5^{\text {a }}$ ed.

As Troianas. Tradução do grego Mario da Gama Kury. Rio de Janeiro:

Ed. Jorge Zahar. 2001, $5^{\text {a }}$ ed.

Hécuba. Tradução do grego Mario da Gama Kury. Rio de Janeiro: Ed.

Jorge Zahar. 2004, $5^{\text {a }}$ ed.

Ifigênia em Áulis. Tradução do grego Mario da Gama Kury. Rio de Janeiro: Ed. Jorge Zahar. 2005, $5^{\text {a }}$ ed.

As Fenícias. Tradução do grego Mario da Gama Kury. Rio de Janeiro: Ed.

Jorge Zahar. 2005, $5^{\text {a }}$ ed.

As Bacantes. Tradução do grego Mario da Gama Kury. Rio de Janeiro:

Ed. Jorge Zahar. 2005, $5^{\text {a }}$ ed.

FO, Dario. Manual Mínimo do Ator. Tradução de Lucas Baldovino e Carlos Dadid

Szlak. São Paulo: Editora SENAC. 1998.

GIRARD, René. A Violência e o Sagrado. São Paulo: Ed. Paz e Terra. 1990, $2^{a}$ ed.

HESÍODO. Teogonia: A Origem dos Deuses. Tradução de Jaa Torrano. São Paulo:

Iluminuras. 2003, $5^{\mathrm{a}}$ ed.

HOMERO. A Ilíada. São Paulo: Ed. Atena. 1958, 2ª ed.

JAEGER, Werner Wilhelm. Paidéia: A Formação do Homem Grego. Tradução de Artur M. Parreira. São Paulo: Ed. Martins Fontes. 1986.

KERÉNYI, Carl. Dioniso: Imagem Arquetípica da Vida Indestrutível. Tradução de Ordep Trindade Serra. São Paulo: Odysseus. 2002. 
KNOX, Bernard. Édipo em Tebas: o Herói Trágico de Sófocles e seu Tempo. Tradução de Margarida Goldsztyn. São Paulo: Ed. Perspectiva. 2002.

LESKY, Albin. A Tragédia Grega. Tradução de J. Guinsburg, Geraldo Gerson de Souza e Alberto Guzik. São Paulo: Ed. Perspectiva. 1976, $2^{\mathrm{a}}$.

MAFFRE, Jean-Jacques. O Século de Péricles. Tradução de Maria do Carmo Pires. Lisboa: Ed. Publicações Europa-América Ltda. 1990.

MARShALL, Francisco. Édipo Tirano: A Tragédia do Saber. Porto Alegre: Editora Universidade Federal do Rio Grande do Sul.. 2000.

MOSSÉ, Claude. Atenas: a História de uma Democracia. Tradução de João Batista da Costa. Brasília: Editora Universidade de Brasília. 1997. $3^{\text {a }}$ ed.

MOUSSINAC, Leon. História do Teatro. São Paulo: Ed. Livraria Bertrand. 1957.

NIETZSCHE, Friedrich Wilhelm. A Origem da Tragédia. São Paulo: Centauro. 2004. S.P. $5^{\mathrm{a}}$ ed.

PAVIS, Patrice. Dicionário de Teatro. São Paulo: Ed. Perspectiva. 1999.

PLUTARCO. Péricles Reformador de Atenas. Tradução de Lobo Vilela. Lisboa: Ed. Inquérito. 1938.

PULQUÉRITO, Manuel de Oliveira. Problemática da Tragédia Sofocliana. Coimbra, Portugal: Editora Instituto Nacional de Investigação Científica. 1987.

RINNE, Olga. Medéia: o Direito à Ira e ao Ciúme. Tradução de Margit Martincic e Daniel Camarinha da Silva. São Paulo: Editora Cultrix. 1988.

ROMILLY, Jacqueline de. A Tragédia Grega. Tradução de Ivo Martinazzo. Brasília: Editora Universidade de Brasília, 1998.

RUDNYTSKY, Peter L. Freud e Édipo. Tradução de Maria Clara Cescatto. São Paulo: Ed. Perspectiva. 2002. 
SAINT-VICTOR, Paul de. As Duas Máscaras. Tradução de Gilson César Cardoso de Sousa. São Paulo: Editora Germape. 2003.

SÓFOCLES. Ájax. Tradução de Trajano Vieira. São Paulo: Ed. Perspectiva. 1997. Antígona. Tradução do grego Mario da Gama Kury. Rio de Janeiro: Ed. Jorge Zahar. 2001, $5^{\text {a }}$ ed. . Édipo em Colono. Tradução do grego Mario da Gama Kury. Rio de Janeiro: Ed. Jorge Zahar. 2001, $5^{\mathrm{a}}$ ed. Édipo Rei. Tradução do grego Mario da Gama Kury. Rio de Janeiro: Ed. Jorge Zahar. 2001, $5^{\mathrm{a}}$ ed. As Traquínias. Tradução de Maria do Céu Zambujo Fialho. Brasília: Editora Universidade de Brasília. 1996.

SPALDING, Tassilo Orpheu. Dicionário de Mitologia Greco-Latina. Belo Horizonte: Ed. Itatiaia. 1965.

TUCÍDIDES. História da Guerra do Peloponeso. Tradução do grego: Mário da Gama Kury. Brasília: Ed. Universidade de Brasília. 2001, 4ª ed.

VERnANT, Jean-Pierre. As Origens do Pensamento Grego. Tradução de Ísis Borges B. da Fonseca. Rio de Janeiro: Editora Difel. 2002. $12^{\mathrm{a}}$ ed.

.Mito e Pensamento entre os Gregos: Estudos de Psicologia

Histórica. Tradução de Haiganuch Sarian. Rio de Janeiro: Paz e Terra. 1990.

VERNANT, Jean-Pierre; VIDAL-NAQUET, Pierre. Mito e Tragédia na Grécia Antiga I e II. Tradução de Anna Lia A. de Almeida Prado, Filomena Yoshie Hirata Garcia e Maria da Conceição M. Cavalcante. São Paulo: Ed. Perspectiva. 1999. 